GEOM - A THERMAL-HYDRAULIC STRESS CODE

AEC Research and Development Report 


\section{DISCLAIMER}

This report was prepared as an account of work sponsored by an agency of the United States Government. Neither the United States Government nor any agency Thereof, nor any of their employees, makes any warranty, express or implied, or assumes any legal liability or responsibility for the accuracy, completeness, or usefulness of any information, apparatus, product, or process disclosed, or represents that its use would not infringe privately owned rights. Reference herein to any specific commercial product, process, or service by trade name, trademark, manufacturer, or otherwise does not necessarily constitute or imply its endorsement, recommendation, or favoring by the United States Government or any agency thereof. The views and opinions of authors expressed herein do not necessarily state or reflect those of the United States Government or any agency thereof. 


\section{DISCLAIMER}

Portions of this document may be illegible in electronic image products. Images are produced from the best available original document. 


\section{NOTICE}

This report was prepared as an account of work sponsored by the United States Government. Neither the United States nor the United States Atomic Energy Commission, nor any of their employees, nor any of their contractors, subcontractors, or their employees, makes any warranty, express or implied, or assumes any legal liability or responsibility for the accuracy, completeness or usefulness of any information, apparatus, product or process disclosed, or represents that its use would not infringe privately owned rights.

Printed in the United States of America

Available from

National Technical Information Service

U.S. Department of Commerce 5285 Port Royal Road

Springfield, Virginia 22151

Price: Printed Copy \$3:00; Microfiche \$0.95 


\title{
GEOM - A THERMAL-HYDRAULIC
}

STRESS CODE

\author{
E. MOODY
}

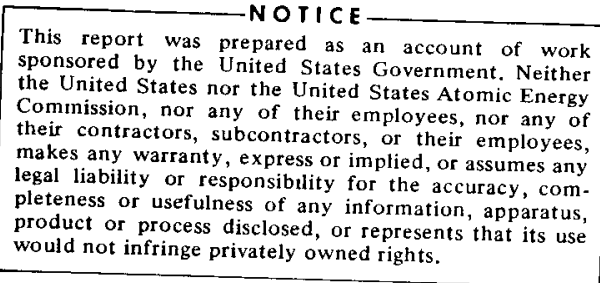

would not infringe privately owned rights.

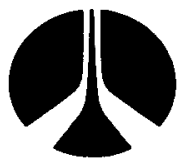

Atomics International Division

Rockwell International

P.O. Box 309

Canoga Park, Cah,ıfornia 91304 


\section{DISTRIBUTION}

This report has been distributed according to the category "Systems for Nuclear Auxiliary Power (SNAP) Reactor - SNAP Program," as given in the Standard Distribution for Classified Scientific and Technical Reports, M-3679. 


\section{CONTENTS}

Page

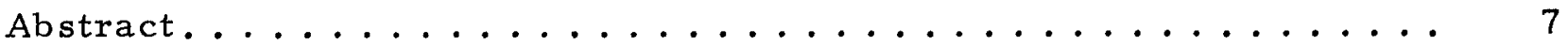

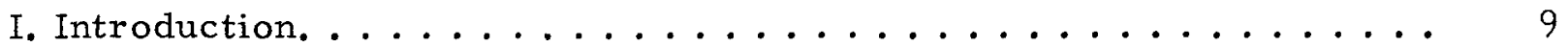

II. Program Development History . . . . . . . . . . . . . . Il

III. Calculational Methods . . . . . . . . . . . . . . . . 15

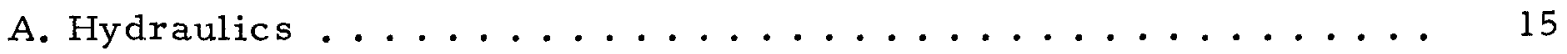

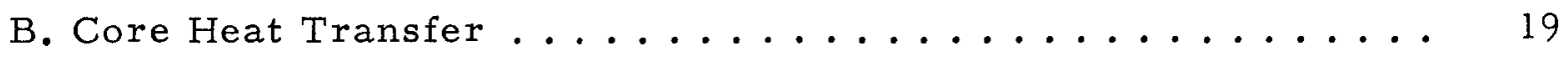

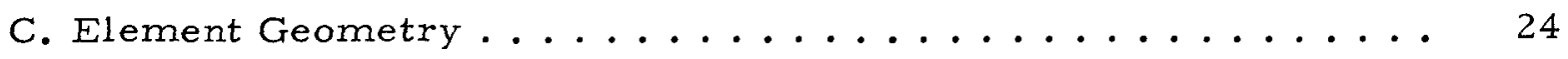

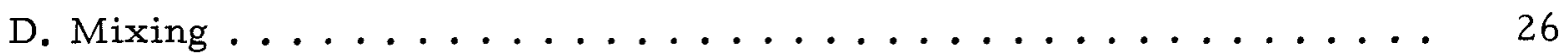

E. Core Periphery Heat Transfer . . . . . . . . . . . . 28

F. Cladding Temperature Variation.............. 28

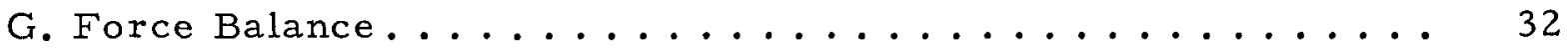

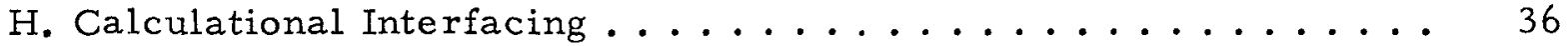

IV. Programming Techniques .................... 41

A. 30-Degree Sector Symmetry. ................. 41

B. Built-In Data ........................ 41

C. Area and Gap Multipliers................... 41

D. Iterative Techniques.......................... 42

E. Table Look Up......................... . . . 43

F. Simultaneous Equation Solution. . . . . . . . . . . . 44

G. Program Structure....................... 44

V. Program Use. . . . . . . . . . . . . . . . . . . 47

A. Input Data Requirements . . . . . . . . . . . . . . 47

B. Program Options ........................... 54

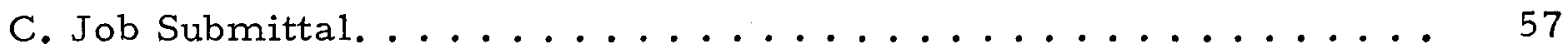

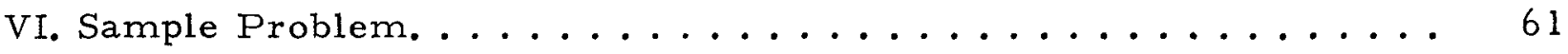

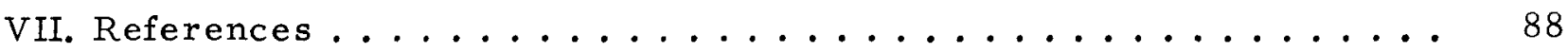




\section{TABLES}

Page

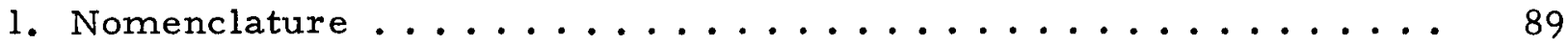

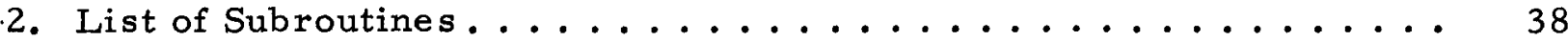

3. /DATIN/ Labeled Common Description . . . . . . . . . . . . 48

4. /DATOUT/Labeled Common Description.............. 52

5. /FRCBAL/ Labeled Common Description............... 53

6. /SHRT / Labeled Common Description ............... 53

7. Typical Input Data Sheet ... . . . . . . . . . . . . . . 64

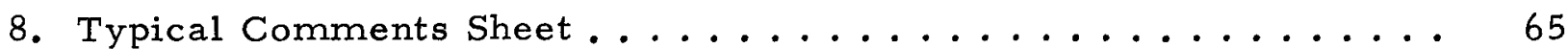

9. Typical Random Vector Sheet................... 66

10. Typical Random Clad Sheet ................... 67

11. Typical Random Asymmetry Sheet. . . . . . . . . . . . . 68

12. Typical Bow Summary Sheet. . . . . . . . . . . . . . 69

13. Typical Core Average Sheet. . . . . . . . . . . . . 70

14. Typical Coolant Temperature Sheet ............... 71

15. Typical Channel Area Sheet . . . . . . . . . . . . . . . 72

16. Typical Coolant Flow Sheet .................... 73

17. Typical Mixing Factor Sheet. .................. 74

18. Typical Film Coefficient Sheet .................. 75

19. Typical Element Temperature Sheet ................ 76

20. Typical Temperature Summary Sheet. . . . . . . . . . . . 77

21. Typical Edge Heat Loss Sheet. . . . . . . . . . . . . . 78

22. Typical Internal Reflector Core Side Sheet . . . . . . . . . . . 79

23. Typical Internal Reflector Shell Side Sheet . . . . . . . . . . 8 80

24. Typical Pressure Vessel Sheet.................... 81

25. Typical Area Summary Sheet ................... 82

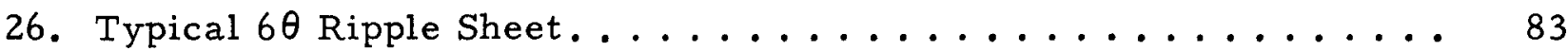

27. Typical Equivalent $\Delta \mathrm{T}$ Sheet. .................... 84

28. Typical Force Balance Sheet . . . . . . . . . . . . . . 85

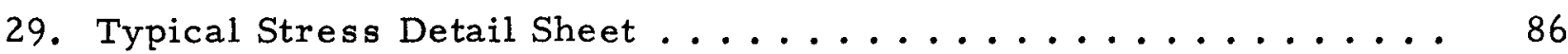

30. Typical Interference Check Sheet ................ 87 
1. GEOM2 30 -Degree Model. . . . . . . . . . . . . . . . 10

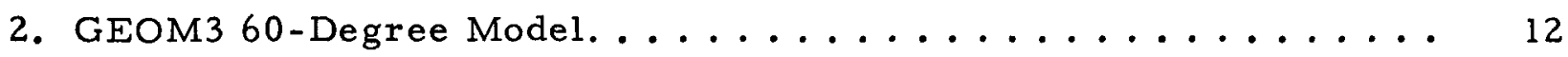

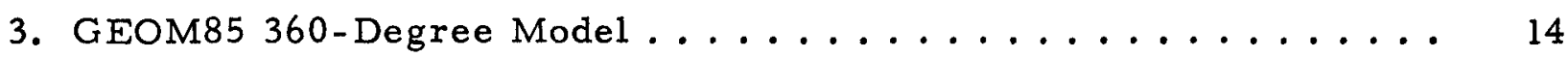

4. Friction Factor Test Data Correlation. ............... 17

5. y Factor Approximation ......................... 18

6. Fuel Element Thermal Model................... 20

7. Nusselt Number vs $\mathrm{P} / \mathrm{d} \ldots \ldots \ldots \ldots \ldots \ldots$

8. Fuel Element Dimensional Model ................. 25

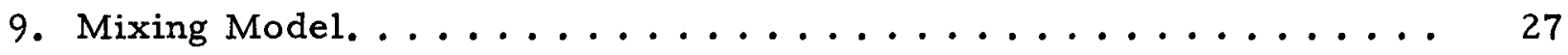

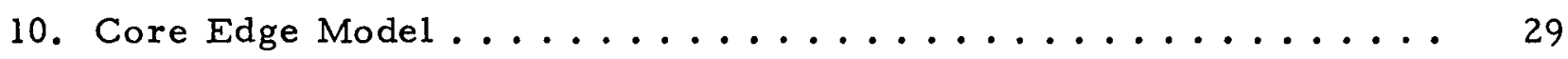

11. Typical Clad Temperature Profile................. 31

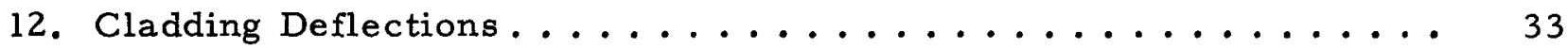

13. Element Force and Deflection Model ................ 35

14. Program Flow Diagram. . . . . . . . . . . . . . . 37

15. 30-Degree Repeating Sector. . . . . . . . . . . . . . 40

16. Cluster and Asymmetry Models .................. 42

17. Program Overlay Structure . . . . . . . . . . . . . . . 45

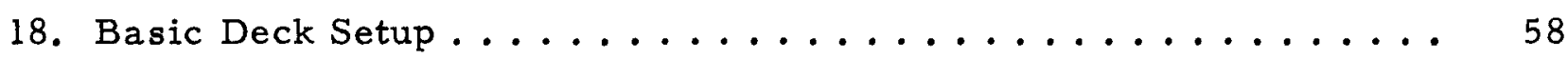


BLANK 


\begin{abstract}
This report documents the GEOM computer code (IBM/360) as it existed at the SNAP program close out. The code performs thermal, hydraulic and stress analysis on a liquid metal $\mathrm{ZrH}$ reactor core. The theory and empirical data used are described in detail. Instructions for using the code are given with a sample problem for illustration.
\end{abstract}


BLANK 


\section{INTRODUCTION}

It is necessary to know the thermal environment in which a fuel element operates in order to determine fuel swelling, hydrogen leakage, and cladding stresses. The thermal environment is controlled by element deflections (which govern flow channel area), power distribution through the core, and the position of the fuel rod in the cladding (fuel asymmetry).

A three-dimensional model of a reactor core has been developed to compute the thermal and hydraulic analyses required. A force balance subroutine system has been developed to permit calculation of element bow shape (as well as element loads) thereby determining channel area variation to enable calculation of the flow distribution.

This document describes the theory and empirical data used in the code. The programming techniques are delineated and instructions are given for program use. A sample problem is included for illustrative purposes. 


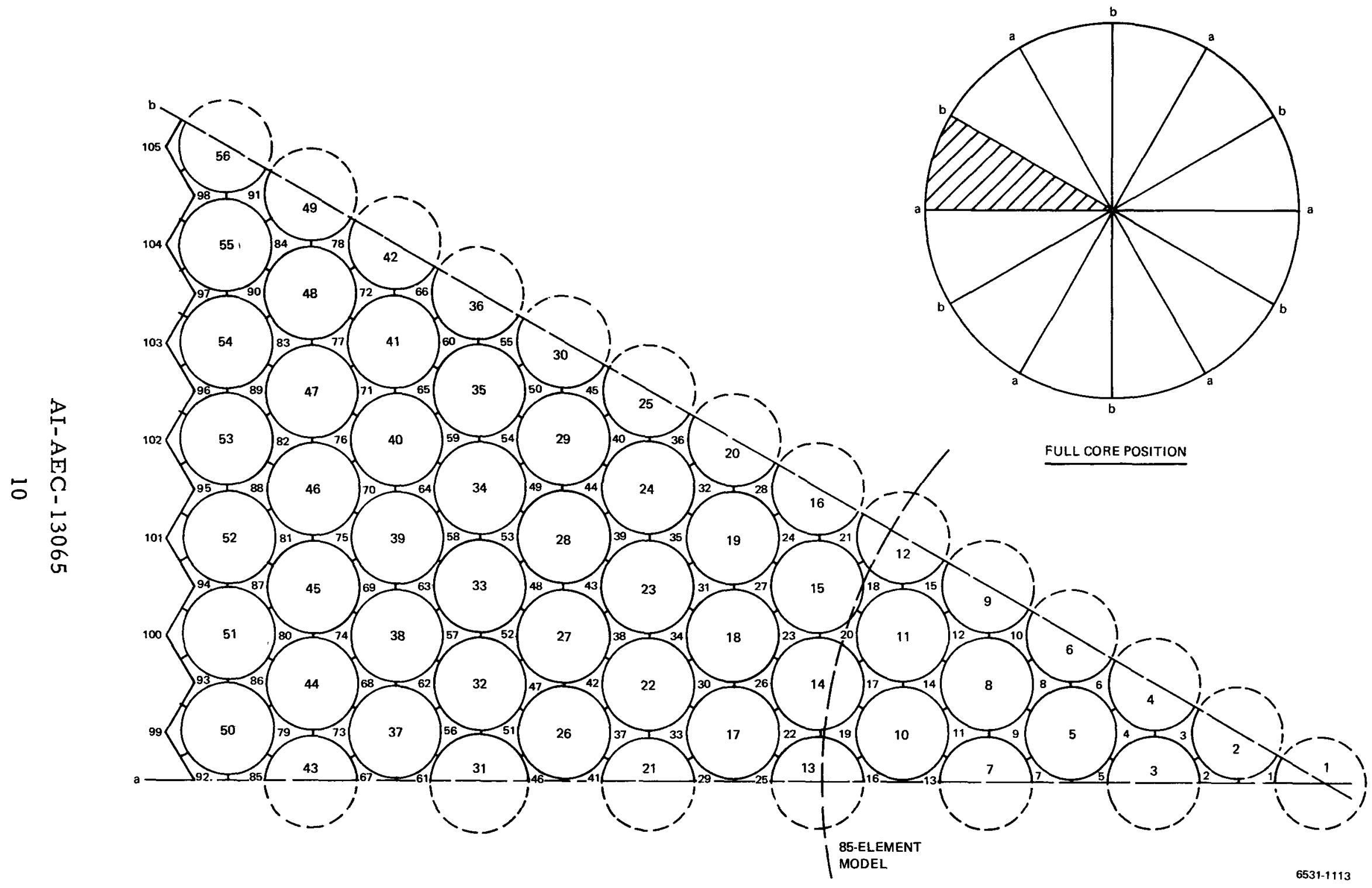

Figure 1. GEOM2 30-Degree Model 


\section{PROGRAM DEVELOPMENT HISTORY}

The initial purpose of developing the GEOM code was to account for the fact that the triangular array fuel element arrangement results in unique thermalhydraulic characteristics for each element in the core. Prior to the advent of the first GEOM code, analysis had been conducted for an average element in each ring. This necessitated that the element be completely symmetric and straight.

The first version of GEOM considered a 30 -degree sector of the core (Figure 1). The total core then consisted of 12 of the se segments arranged as if the segment were rotated around one side 12 times to make a full circle. This code (GEOM2) was documented in March 1970. (1) It was capable of handling any size core to a maximum of 511 elements. Over a 1-year period, GEOM2 was continually revised to increase the program capability in a series of 11 bulletins. Major improvements included the capability of considering bowed clad and asymmetric fuel, improved heat transfer and fluid mixing calculations, and output suitable for input to stress analysis codes.

It became apparent that the boundary limits imposed by the 30-degree segment resulted in severely limiting the ability to properly analyze the effects of design improvements being developed during that period, primarily the rightleft-neutral (RLN) fin arrangement to promote cross flow. Therefore, in April 1971, the program was revised to consider a 60-degree core segment (Figure 2) and renamed GEOM3. (2) This revision reduced the number of elements which could be handled to 331 to keep the program within reasonable core storage requirements. This version of the code was also revised periodically to stay abreast of current design developments and test data, primarily in the area of hydraulics.

GEOM2 and GEOM3 were also affected by the then-current core designs. GEOM2 was in the era of the 295-element, 600-kwt core and GEOM3 was during the 199-element, 300-kwt phase. When the reactor design shifted to 85 elements at $100 \mathrm{kwt}$, it became apparent that a full 360 -degree model of this core could be handled within computer limitations. Further, stress analysis efforts had 


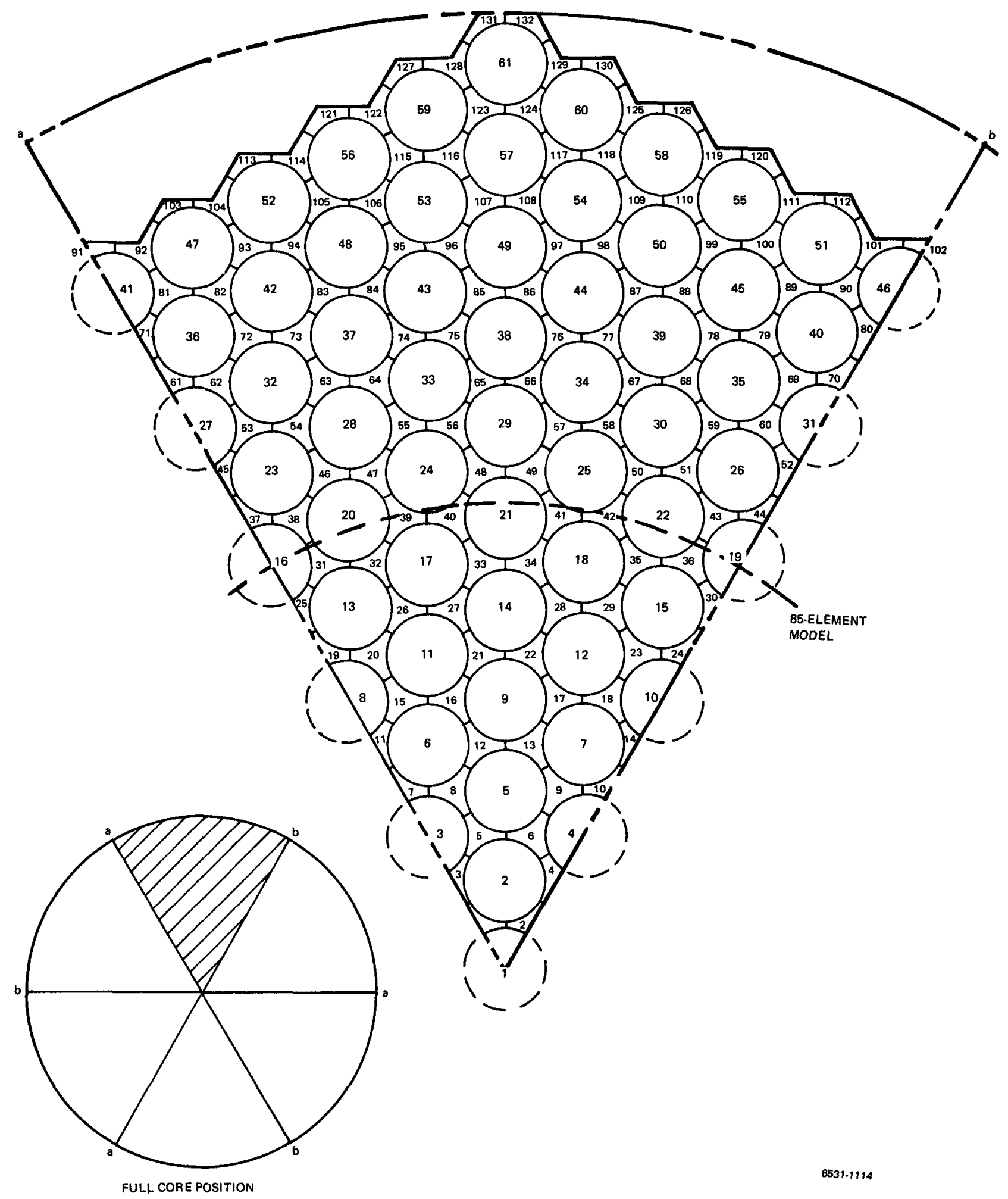

Figure 2. GEOM3 60-Degree Model 
progressed to the code development stage so that it appeared feasible to incorporate a force balance and stress routines to permit a complete rod bundle analysis in a single step.

This effort (GEOM85) was initiated in early 1972 using an 85-element model (Figure 3), also capable of analyzing 55-, 37-, 19-, and 7-element configurations. The initial documentation was released in April $1972^{(3)}$ and the force balance became operable in July 1972. Efforts were made during the GEOM85 development to upgrade GEOM3 accordingly for use in parametric studies because it was recognized that GEOM 85 would be more costly to run. The attempt was only partially successful, however, and GEOM3 is no longer used.

GEOM85 incorporates all the features developed in GEOM2 and GEOM3 except the CRT output built in to GEOM2 as this option was rarely used. The documentation contained in this report refers in all cases to GEOM85. 


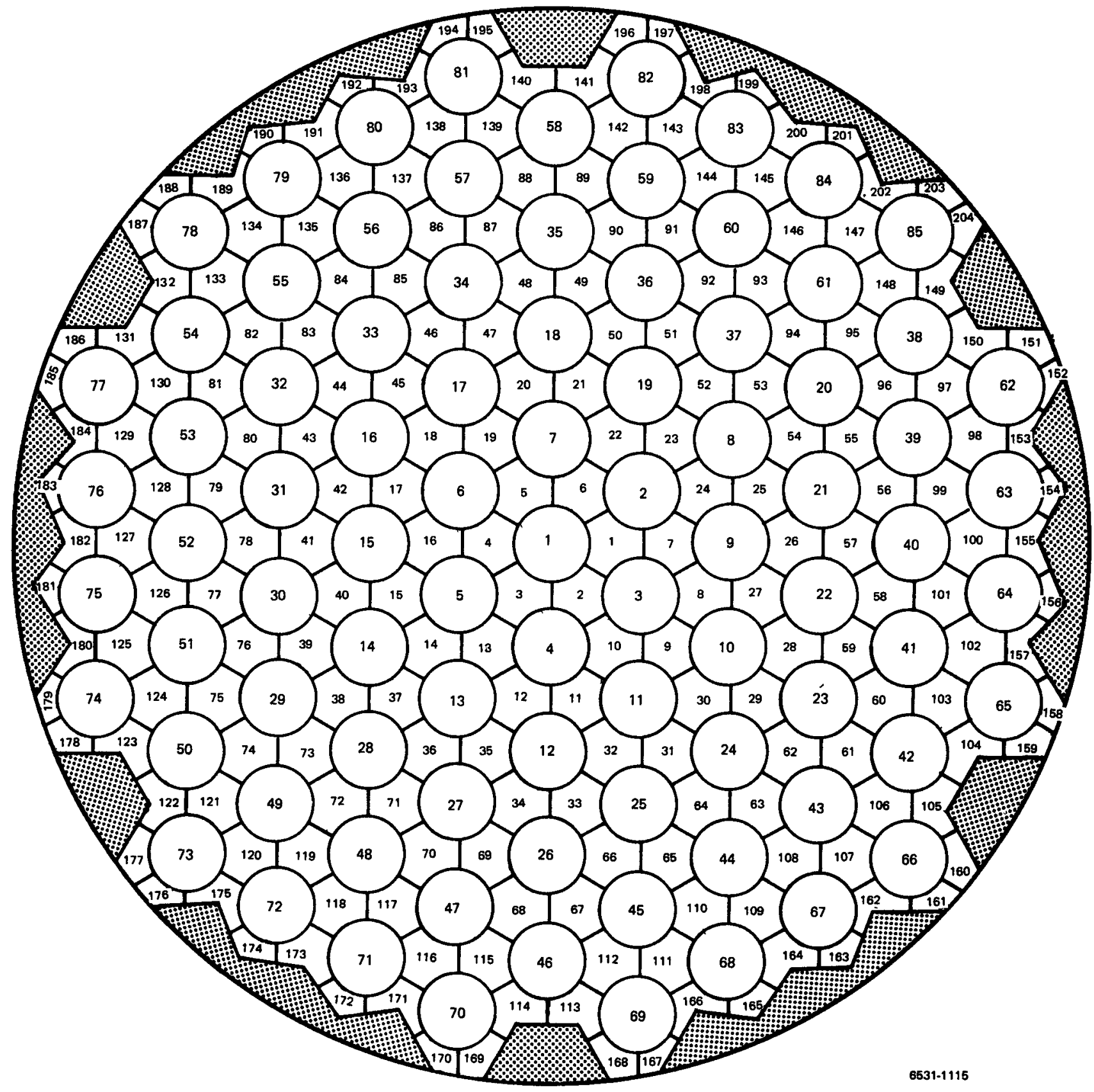

Figure 3. GEOM85 360-Degree Model 


\section{CALCULATIONAL METHODS}

To obtain the required three-dimensional model, the program has been set up to handle a nodal network, both axially and radially. Because the heat transfer element deflections and hydraulics are interdependent, the program uses iterative techniques for solution of the various equation sets treated. There are six major areas of computation in the code. This section describes the equations and methods used for this solution and the methods used to obtain the total solution. Table 1 gives nomenclature used.'

\section{A. HYDRAULICS}

Flow through a close-packed rod bundle is highly dependent on the geometry. The principal factors are the element-to-element spacing and the geometry of fins if used. The code considers the right-left-neutral (RLN) fin configuration adopted by Atomics International (AI) as a SNAP reactor standard feature, since test results have shown this configuration to give maximum cross-channel coolant flow. A test series run at $\mathrm{Re} \approx 100,000^{(4)}$ developed an expression which modified the standard Blasius smooth-tube friction factor:

$$
\begin{gathered}
f_{f}=\frac{0.316}{R e^{0.25} y z} \\
z=\frac{4.76}{\left(L_{f} / d\right) 0.47} \\
(z=1 \text { for smooth tubes })
\end{gathered}
$$

The spacing parameter y was a compendium of tests run by experimenters in Russia, Germany and the U.S. The fin parameter z considered a single wire wrap. This averages out to $1 / 2 \mathrm{fin}$ in the channel. In addition, the wire wrap was tight against the adjacent rod or vessel wall, whereas tolerances on actual core bundles can cause gaps. Therefore, $z$ was modified to:

$$
z=\frac{4.76}{\left(\frac{L_{f}}{d} \frac{N}{0.5} \frac{S}{h_{f}}\right)^{0.5}}
$$

*For reader convenience, this table is placed at the end of the report as a foldout page. 
Early mixing tests run at AI covered the range of $8000 \leq \mathrm{Re} \leq 20,000$ and Equation 1 was found satisfactory using the modified $z$. These tests were run using plastic fins glued to smooth tubes. Later tests were run with hobbed fins and lower Reynolds numbers. Figure 4 shows the results of the two test series. It is apparent that a straight line does not fit the data over the full range of $R_{e} \cdot$ Therefore, the equation was modified to approximate the curvature. The 4.76 constant in $z$ was combined with the smooth-tube constant:

$$
\begin{gathered}
f_{f}=237 y / z\left(\ln R_{e}\right)^{-3.72} \\
z=\left(\frac{L_{f}}{d} \frac{N}{0.5} \frac{S}{h_{f}}\right) \\
(z=4.76 \text { for smooth tubes }) .
\end{gathered}
$$

The test data was taken over a 19-element bundle and as a result considers an average channel. Channels at the core edge, however, have peculiar geometries and would therefore not be expected to exhibit flow characteristics identical to those of a full tri-cusp channel. The closest data available for similar geometries was that for eccentric annuli, (5) which indicated a strong friction factor dependency on the diameter ratio of the annulus. Using a fictitious pitch/ diameter ratio $(P / d)$ developed from the equation relating tri-cusp area to $\mathrm{P} / \mathrm{d}$, it was possible to calculate an equivalent annular diameter ratio. Using the data of Reference 4 for the $y$ factor, modified for edge channels by the data of Reference 5, the $y$ factor approximation shown in Figure 5 was developed. A test series was planned to confirm or modify this approximation at the time of the SNAP program cancellation, thus the data is questionable but currently the best approximation available.

The program assumes no radial pressure gradients in the core, thus equal pressure drop for all channels over a given axial distance:

$$
\Delta P=f_{f} \frac{V^{2}}{288 g} \frac{L}{d_{H}} \rho=\text { constant }
$$




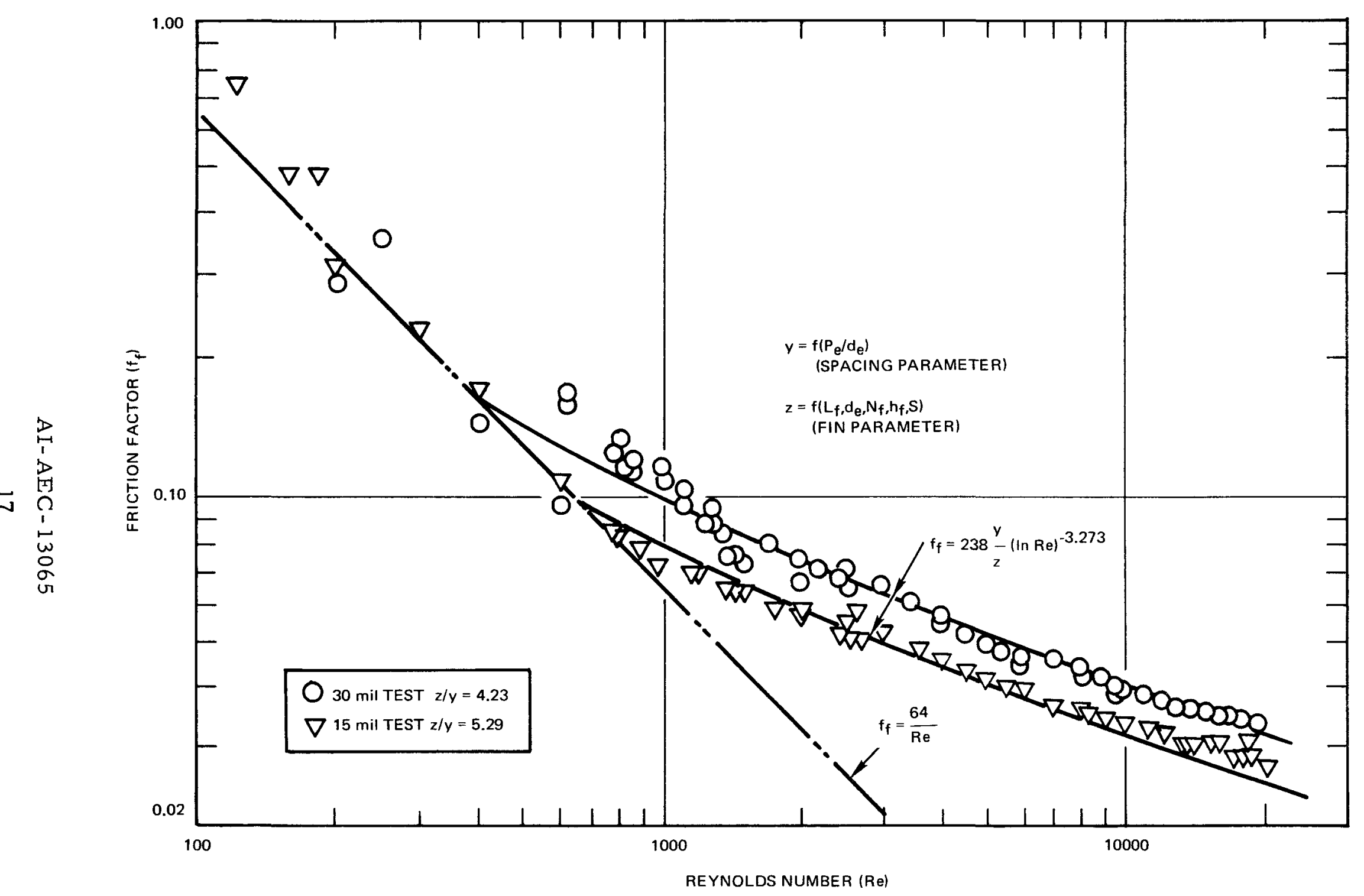

$6531-1116$

Figure 4. Friction Factor Test Data Correlation 


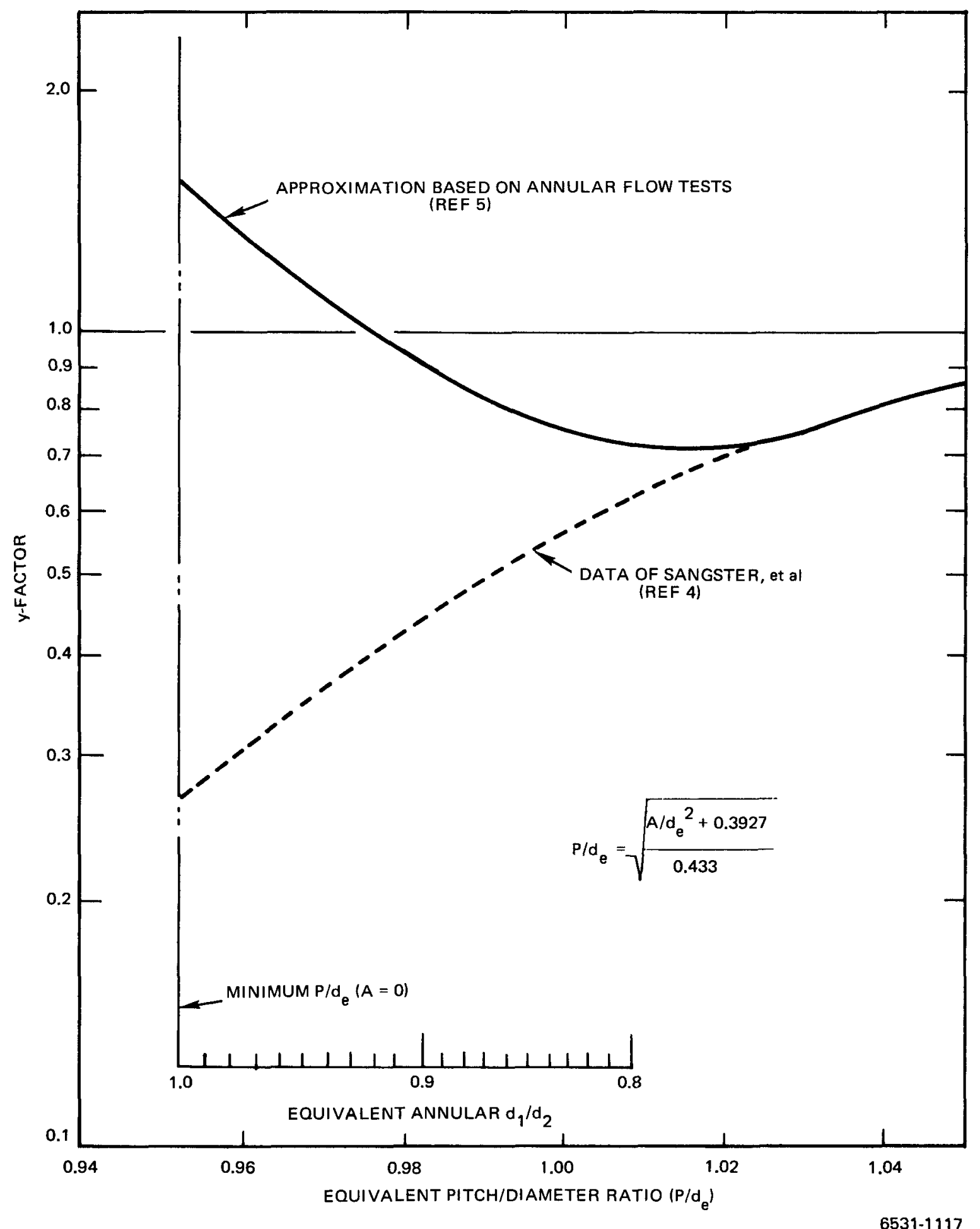

Figure 5. y Factor Approximation 


$$
\therefore \frac{f_{f} v^{2}}{d_{H}}=\text { constant }
$$

Using the relationships:

$$
\begin{gathered}
\dot{\mathrm{w}}=\frac{\mathrm{V}}{25 \rho \mathrm{A}} \\
\mathrm{d}_{\mathrm{H}}=\frac{4 \mathrm{~A}}{\mathrm{P}_{\mathrm{w}}} \\
\mathrm{R}_{\mathrm{e}}=\frac{300 \mathrm{Vd}_{\mathrm{H}} \rho}{\mu}
\end{gathered}
$$

Equation 7 may be restated as:

$$
\dot{\mathrm{w}}_{1} \mathrm{f}_{\mathrm{f}_{1}} \mathrm{P}_{\mathrm{w}_{1}} A_{1}=\dot{\mathrm{w}}_{2} \mathrm{f}_{\mathrm{f}_{2}} \mathrm{P}_{\mathrm{w}_{2}} \mathrm{~A}_{2}
$$

Solution for the flow may be obtained by an iterative procedure, since conditions in an average channel are simply determined by geometry and total flow rate. The transition from turbulent to laminar flow is considered to follow the intersection of the curves of Figure 4.

\section{B. CORE HEAT TRANSFER}

The $\mathrm{ZrH}$ fuel rod must provide clearance for swelling which occurs as a result of uranium burnup and hydrogen loss. As a result, there is a gas gap between the fuel rod and cladding. A ceramic barrier is placed on the inside cladding wall to minimize hydrogen loss. Figure 6 shows the thermal model of the fuel element used in the program. Note that this drawing is only one small portion of the total nodal network interconnecting the entire core.

The heat transfer by conduction is calculated by:

$$
\mathrm{q}=\frac{\Delta \mathrm{T}}{\mathrm{R}}
$$




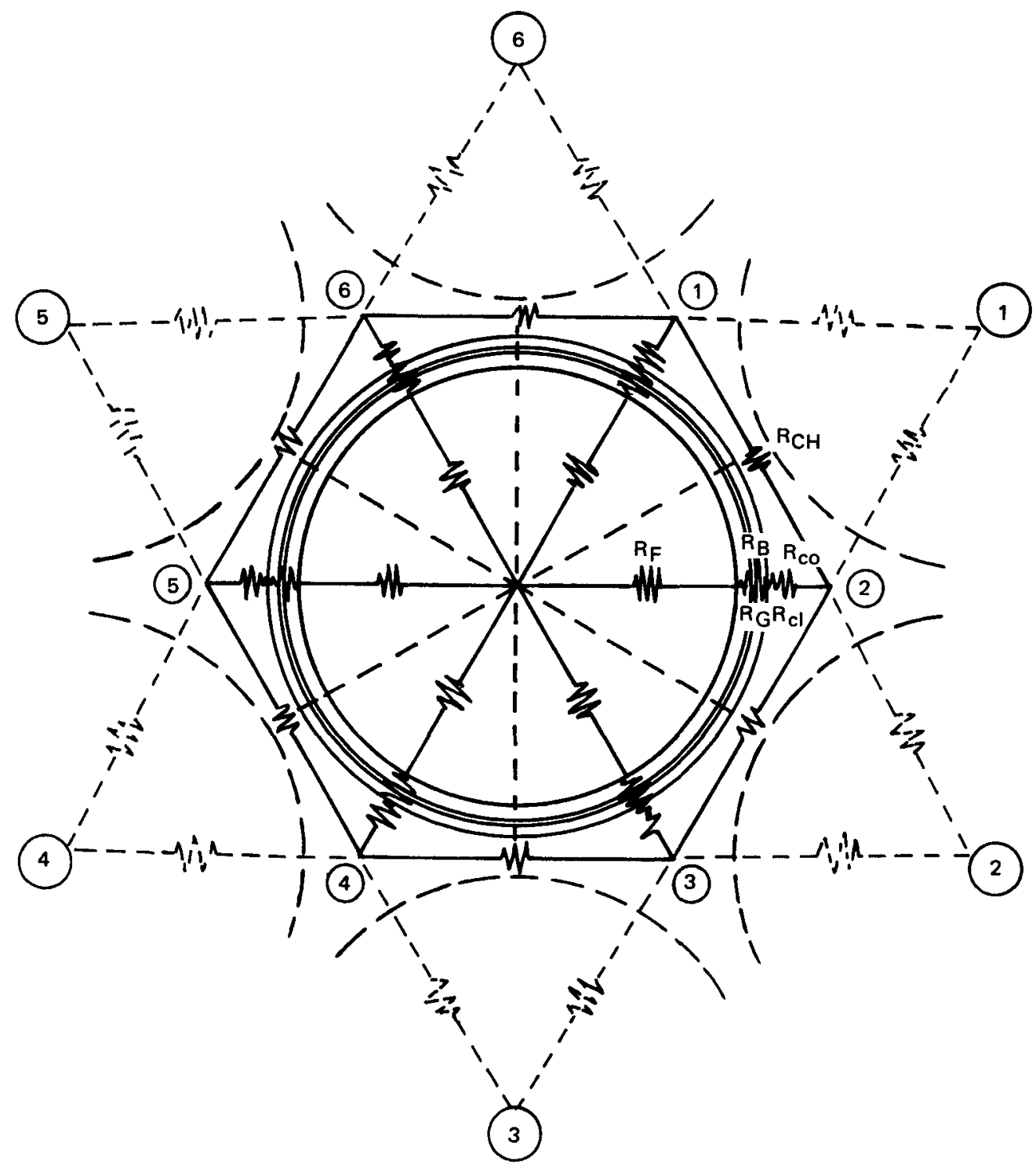

$$
\begin{aligned}
& \text { THERMAL RESISTANCES } \\
& \begin{array}{l}
\mathbf{R}_{\mathbf{F}}=\text { FUEL } \\
\mathbf{R}_{\mathrm{G}}=\text { GAS GAP } \\
\mathbf{R}_{\mathbf{B}}=\text { BARRIER } \\
\mathbf{R}_{\mathrm{Cl}}=\text { CLAD } \\
\mathbf{R}_{\text {CO }}=\text { COOLANT } \\
\mathbf{R}_{\mathrm{CH}}=\text { CHANNEL }
\end{array}
\end{aligned}
$$

Figure 6. Fuel Element Thermal Model 
where:

$$
\begin{aligned}
& R_{c o}=\frac{36}{\pi h_{c o} r_{c o}} \\
& R_{c l}=\frac{3^{t}{ }_{c l}}{\pi k_{c l}{ }^{r} c l} \\
& R_{B}=\frac{3^{t} r_{B}}{\pi k_{B} r_{B}} \\
& R_{G}=\frac{3^{t} k_{G}}{\pi k_{G} r_{G}} \\
& R_{F}=\frac{6}{4 \pi k_{F}}
\end{aligned}
$$

The fuel rod heat flux to each channel (n) is:

$$
Q_{n}=k_{n}\left(3412.874 \overline{\mathrm{P}} \varphi_{A} \varphi_{R}\right)
$$

where $k_{n}$ is a factor controlled by coolant channel temperature and fuel asymmetry. The coolant temperature is then computed by:

$$
T_{c o_{i+1}}=T_{c o_{i}}+\frac{\sum_{n=1}^{3} q_{i}+\sum_{n=1}^{3} q_{i}+1}{\left(\dot{w}_{i}+\dot{w}_{i+1}\right) c_{p}}
$$

The nodal network is solved iteratively by initially assuming $k_{n}=1 / 6$ and solving for 6 values of fuel temperature to obtain an average value of:

$$
\overline{\mathrm{T}}_{F}=\frac{\sum_{n=1}^{3} \mathrm{~T}_{F}}{6}
$$


If the 6 values are not within a tolerance limit:

$$
k_{n}=\frac{\bar{T}_{F}-T_{c o}}{\sum R\left(3412.874 P \varphi_{A} \varphi_{R}\right)}
$$

and the network is resolved to convergence.

The channel-to-channel heat flow path was added to approximate low-flow, low-power conditions such as a startup transient. Normally, heat transfer is not considered important along this path since mixing results in a mass transfer and the circumferential coolant temperature variation ( $6 \theta$ ripple) around the element precludes conduction. However, when used, the area is the minimum distance between elements times the length of axial segment considered and the thickness is an arbitrary selection by the program user.

While liquid metal does not act like most heat transfer media (such as water) because of its high conductivity, a fictitious film coefficient has been developed and confirmed by test. ${ }^{(6)}$ This coefficient is dependent on $P / d$, clad thickness and mixing. The basic film coefficient considers a 10-mil clad thickness. Figure 7 shows the curve of $\mathrm{Nu}$ vs $\mathrm{P} / \mathrm{d}$. The value of $\mathrm{h}$ thus determined is then modified $^{(7)}$ by the following equations:

$$
\begin{gathered}
h_{t}=h\left[1+\left(\frac{0.02229}{P / d-1}\right)^{0.8}\left(0.4394+\frac{0.004423}{t_{c l}}\right)\right] \\
\quad(\text { clad thickness) } \\
h_{m}=h_{t} 0.9935+0.02875 k_{m}-0.2393(P / d-1) \\
\text { (mixing rate) }
\end{gathered}
$$

The effect of mixing has not been completely verified by test; primarily because of the questionable accuracy of the thermocouples when after two test series (touching elements and ring spaced) fins were brazed to the test elements and a third test series was run. However, the prime question unresolved was the $6 \theta$ ripple effect rather than the film coefficient (Section III.F), and Equation 23 is deemed valid. 


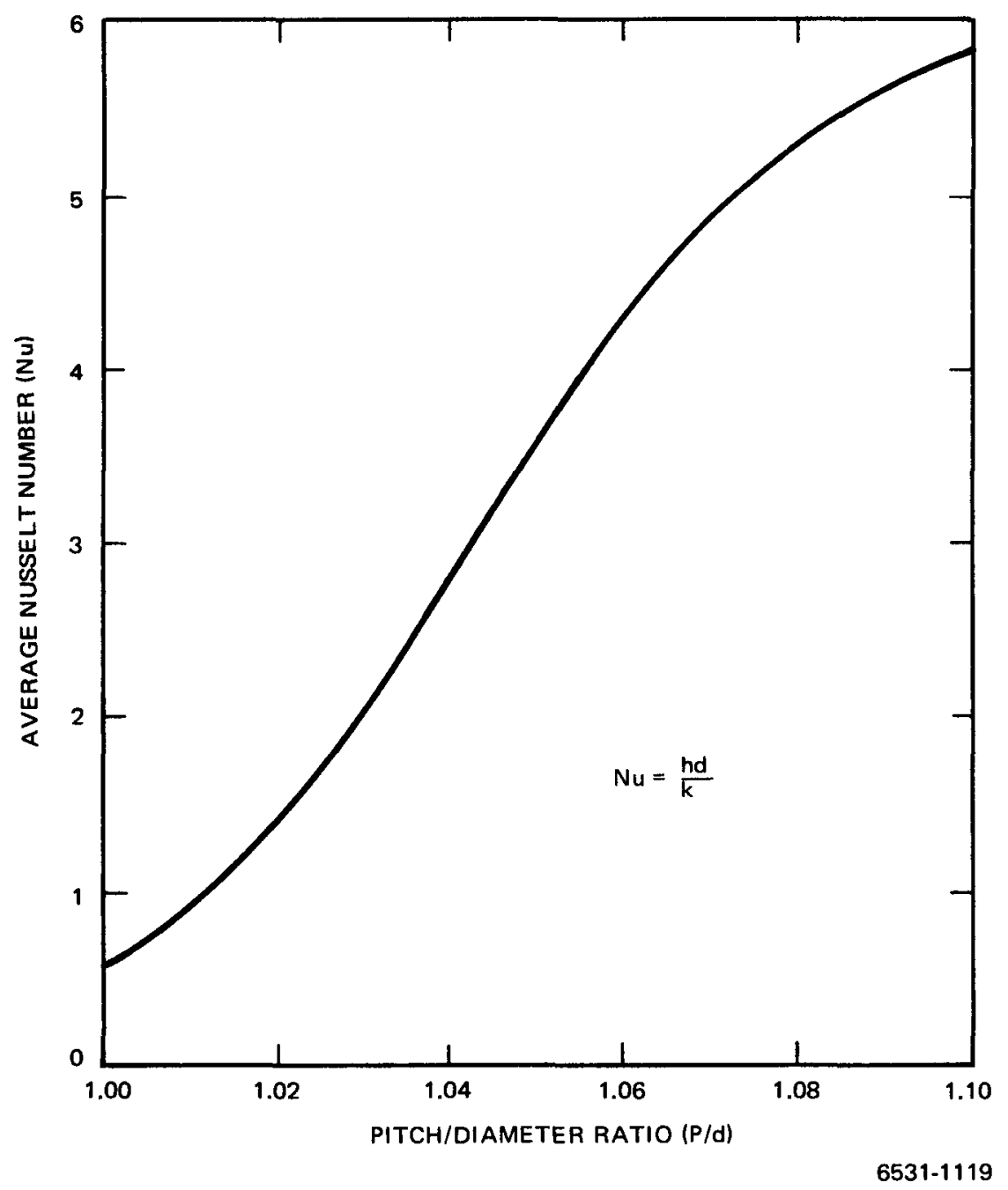

Figure 7. Nusselt Number vs $P / d$ 
The gas gap contains hydrogen released from the $\mathrm{ZrH}$ fuel matrix to attain equilibrium pressure. At low operating power and temperature and during startup, this pressure is very low resulting in free molecular rather than continuum conduction. To decrease this thermal resistance, helium is loaded into the element during manufacture. As a result, the conductivity is that of a mixed gas including the effects of fuel and barrier surface accommodation. Reference 8 gives the method derived for computing gas conductivity based on extensive experimental work conducted at Purdue University. In addition, the heat transfer by radiation from the fuel to the barrier is also considered. The process is necessarily iterative in that the average gap temperature must be solved as it is dependent on the conductivity (which in turn is temperature dependent) as well as the heat flux.

The program considers the average gap width in each of the six segments of the model and also considers the relative thermal expansion of both cladding and fuel.

\section{ELEMENT GEOMETRY}

To attain the three-dimensional model, the core is divided into 11 planes. Two-dimensional calculations are then conducted at each plane, knowing the inlet temperature and successively working from the cold end of the core to the hot end. The location of these planes is at the discretion of the user other than those at the inlet and outlet. Figure 8 shows the element model. Note that the axial nodes are set over the active fuel length for thermal calculations with two more added at the grid plates for hydraulic and stress calculations.

The program will consider segmented fuel in one to five slugs oriented as desired. The fin height may be varied axially. This has been considered in order to control the location of the contact plane, thereby avoiding secondary element contacts. The allowable element tolerance envelope, Total Indicator Runout (TIR) is used to set location and magnitude for manufacturing bows in the stress calculations.

It should be noted that the axial nodes are used for all calculations, thus careful selection is necessary. In the example shown, the ends of the fuel slugs 


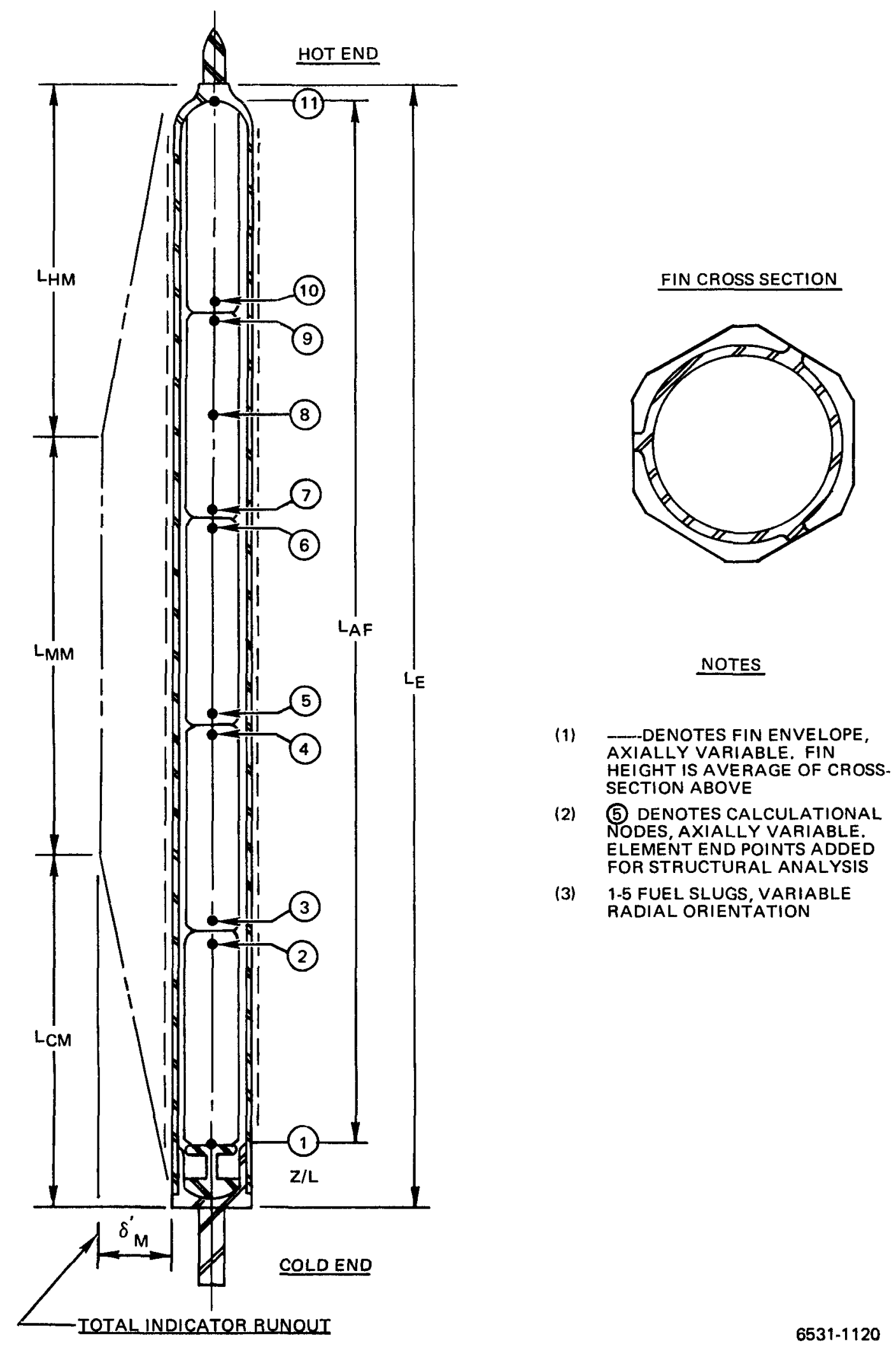

Figure 8. Fuel Element Dimensional Mode1 
governed the selection. In the case of a tapered window-type sliding reflector it would be desirable to analyze the effect of the abrupt reflector discontinuities. If variable fin heights are used, the nodes should cover abrupt variations, etc .

\section{MIXING}

Initially, spacers were considered for positive separation of elements to maintain a relatively constant flow area, thus limiting cross-element temperature gradients. As an extra feature, spiral-type spacers provided crosschannel flow. By using an RLN fin system, a maximum mass transfer is obtained, further reducing cross-element $\Delta T$, thus minimizing element deflections and stresses.

Figure 9 shows the analytical model and equations used to calculate the effects of mixing. Each full channel has one inlet and two outlet or one outlet and two inlet streams as shown. Edge channel flows depend on the type of element involved. Neutral, unfinned elements, do not contribute to the cross flow.

The mixing tests run in a 19-element bundle resulted in the development of the following equation:

$$
k_{M}=\frac{236 P_{e} h_{f}}{P_{f}\left(0.433 P_{e}{ }^{2}-0.3927 d_{e}^{2}-w_{f} h_{f}\right)\left(1+0.91 e^{-45.2 x h_{f}}\right)}
$$

As theoretically expected, mixing is independent of flow but does require a finite axial length to become fully developed. Equations 25 through 28 of Figure 9 are combined to form a total mixing Equation 29. Equations are developed for each core channel and solved simultaneously.

Since flow areas, and therefore flow, may vary axially, the axial flow used for computing cross flow is taken as the average flow around each finned element. While the validity of this as sumption has not been proven in the tests performed, there does not appear to be a more logical method of calculation. Since mixing is so effective in reducing cross-element $\Delta T$, it is felt that this method is adequate for the accuracy which is known for flow distribution per se. 

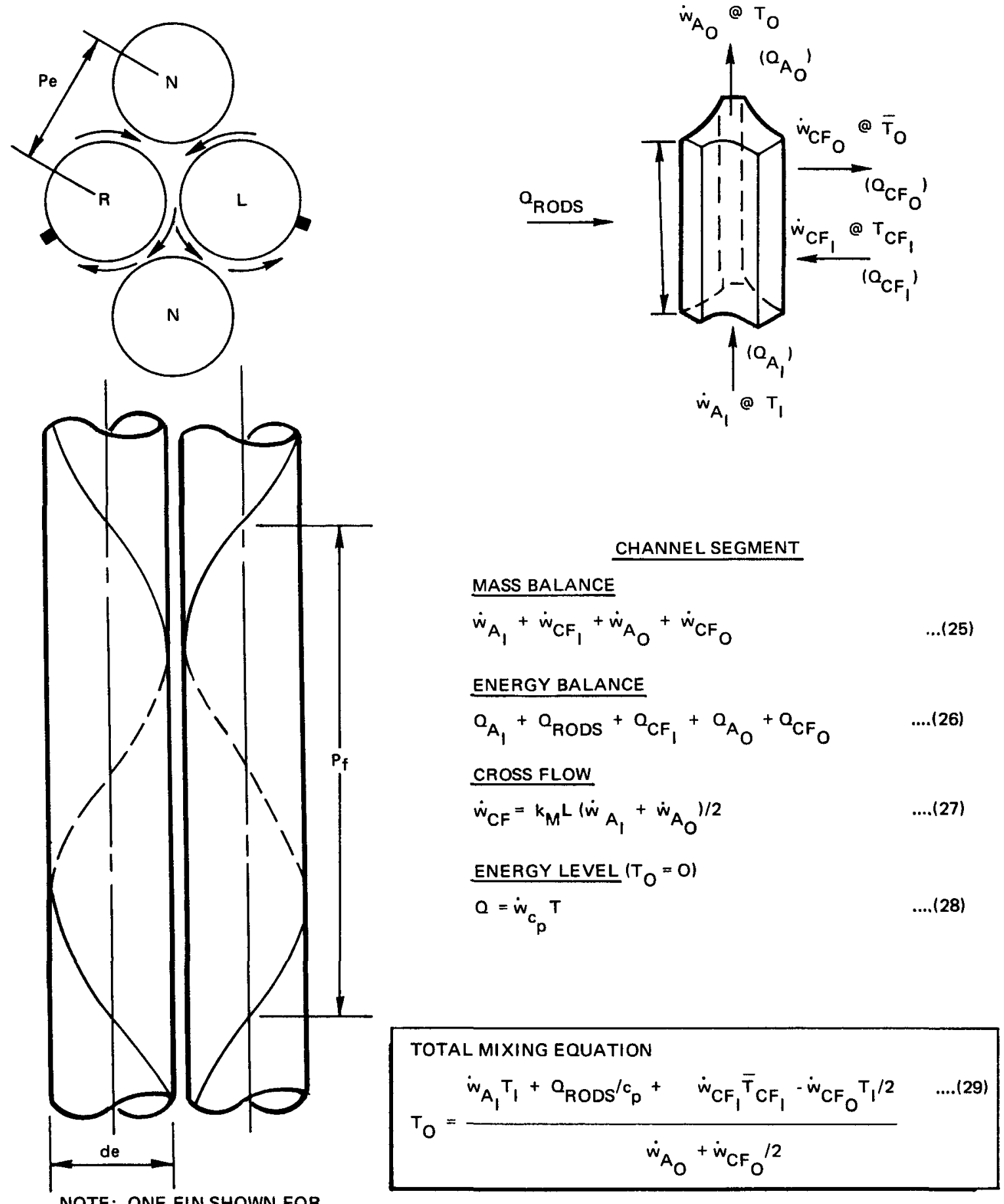

NOTE: ONE FIN SHOWN FOR CLARITY, NORMALLY THREE USED

Figure 9. Mixing Model 


\section{E. CORE PERIPHERY HEAT TRANSFER}

SNAP-type reactors use a cylindrical pressure vessel to contain the coolant. Use of a triangular fuel element array results in areas at the core edge too small to contain an element and too large to serve as a flow channel. To control flow, these areas are filled with reflective materials to reduce the thickness of the external control reflector. Dependent on the ambient environmental conditions, heat transfer is possible in either direction across the internal reflector and pressure vessel.

Figure 10 shows the physical model and nodal network for solution of this heat transfer. A bypass flow is considered since assembly clearances are necessary, making flow between the internal reflectors and pressure vessel possible. Heat transfer from the pressure vessel to ambient may be conductive or radiative depending on whether the external reflectors are attached firmly to the vessel or there is a clearance. The latter is the normal condition.

Using Equation 20 and

$$
\mathrm{q}=\dot{\mathrm{w}} \mathrm{p}_{\mathrm{p}} \Delta \mathrm{T}
$$

an energy balance equation may be written at each node resulting in a set of simultaneous linear equations which may be solved for the nodal temperatures and heat flows. In the case of radiative heat transfer from the vessel, an iterative procedure is necessary since:

$$
R_{V W}=\frac{\left(T_{1}-T_{2}\right)}{q} \sigma F_{e} F_{A} A\left(T_{1}{ }^{4}-T_{2}{ }^{4}\right)
$$

and $\mathrm{q}$ and $\mathrm{T}_{2}$ are unknowns.

\section{F. CLADDING TEMPERATURE VARIATION}

In a close-packed rod bundle, the heat transfer coefficient varies circumferentially, being a maximum at the point of furthest distance to neighboring elements and a minimum at the closest approach. This effect is known as a $6 \theta$ ripple in a triangular array and is caused primarily by velocity profiles 

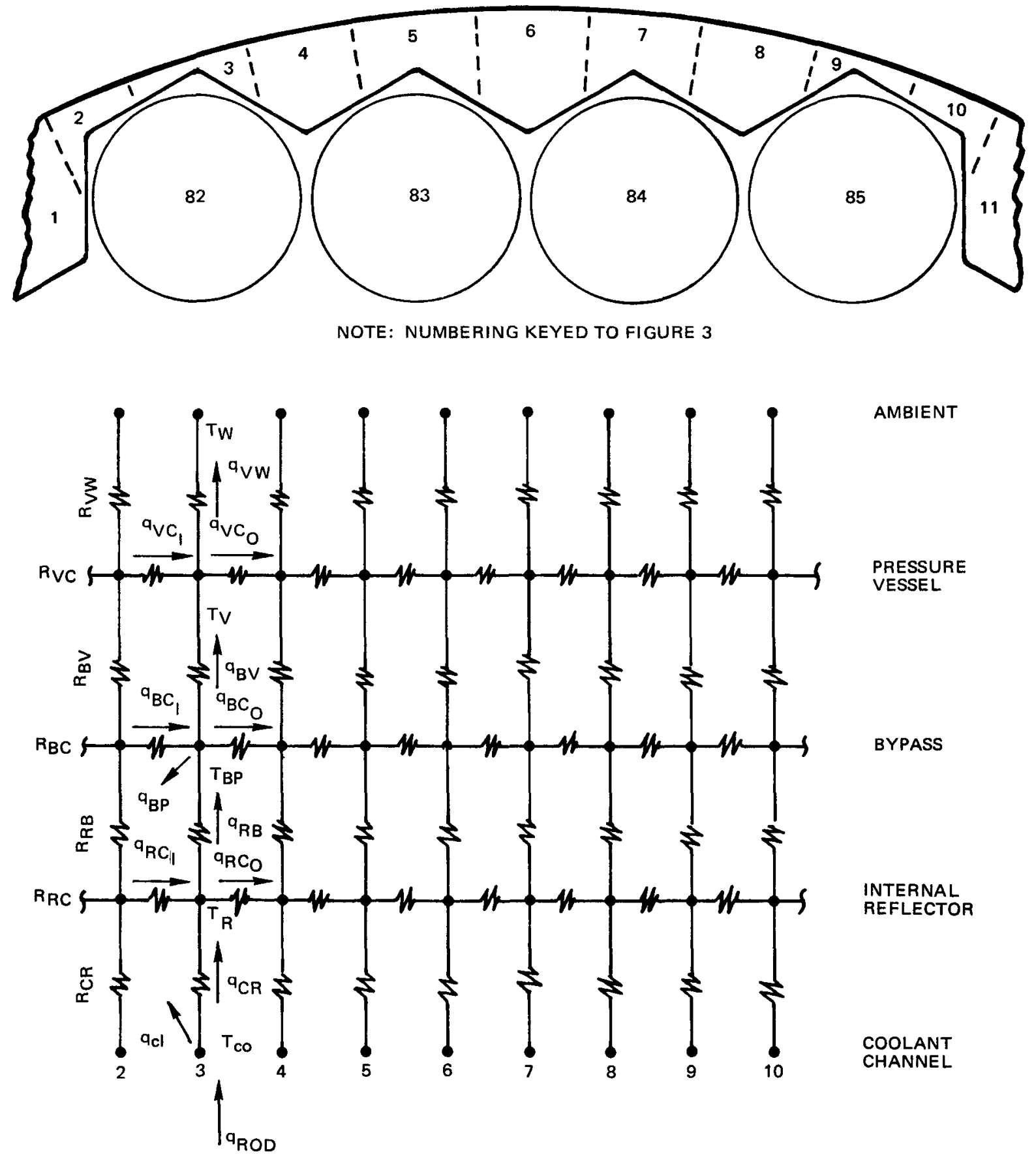

PARTIAL NODAL NETWORK

(FULL NETWORK COVERS $360^{\circ}$ )

Figure 10. Core Edge Model 
in the tri-cusp channel. Much theoretical and experimental work has been done in the U.S. and other countries on this phenomenon. Reference 6 shows the results obtained from heat transfer tests at AI. For smooth tubes, theory and experimental data show extremely good correlation. As previously indicated, the thermocouple data on the finned test is somewhat questionable. Thus, dependent on the method used to analyze the data, the ripple can be considered to exist or to be completely eradicated. Reference 9 shows that the theoretical effect of mixing is to reduce the magnitude of the ripple and also to move the high and low points approximately 10 degrees in the direction of cross flow. Reference 10 shows good agreement with theory and test data analys is which considers a 120-degree segment of a fuel element rather than a 30-degree segment. The test data analysis also showed an offset of the ripple on the order of 15 degrees.

The thermal model of Figure 6 develops average clad and coolant temperatures at six points around the element. The variation is considered to be a sine wave with the following equations developing the high and low points:

$$
T_{c 1}=\bar{T}_{c o}+\left(31.25 t_{c 1}\right)^{-0.4}\left(-3.764+5.125 \times 10^{-4} h_{c o}\right) P D \ldots(31
$$

(note that $h_{\text {co }}$ includes mixing effect at this point)

$$
\mathrm{T}_{\mathrm{cl}}=2 \overline{\mathrm{T}}_{\mathrm{cl}}-\mathrm{T}_{\mathrm{cl}} \mathrm{MIN}_{\mathrm{MAX}}
$$

Since there cannot be thermal discontinuities in the clad, the maximum temperature is taken as the average between those computed for adjacent segments as shown in Figure 11. The data shown is typical for an asymmetric fuel rod where the power density, thus $6 \theta$ ripple magnitude, varies circumferentially.

Since the only purpose of computing the temperature distribution is to obtain stress data, a cosine fit is made to the $6 \theta$ ripple curve to attain a thermal value which causes bending. Locally, the clad is in compression if the $6 \theta$ ripple is above the bending temperature and in tension below. The cosine fit also determines the angle at which the element will bow. Provision is in the code to offset the $6 \theta$ ripple (including proper direction governed by fin pitch) if desired. 


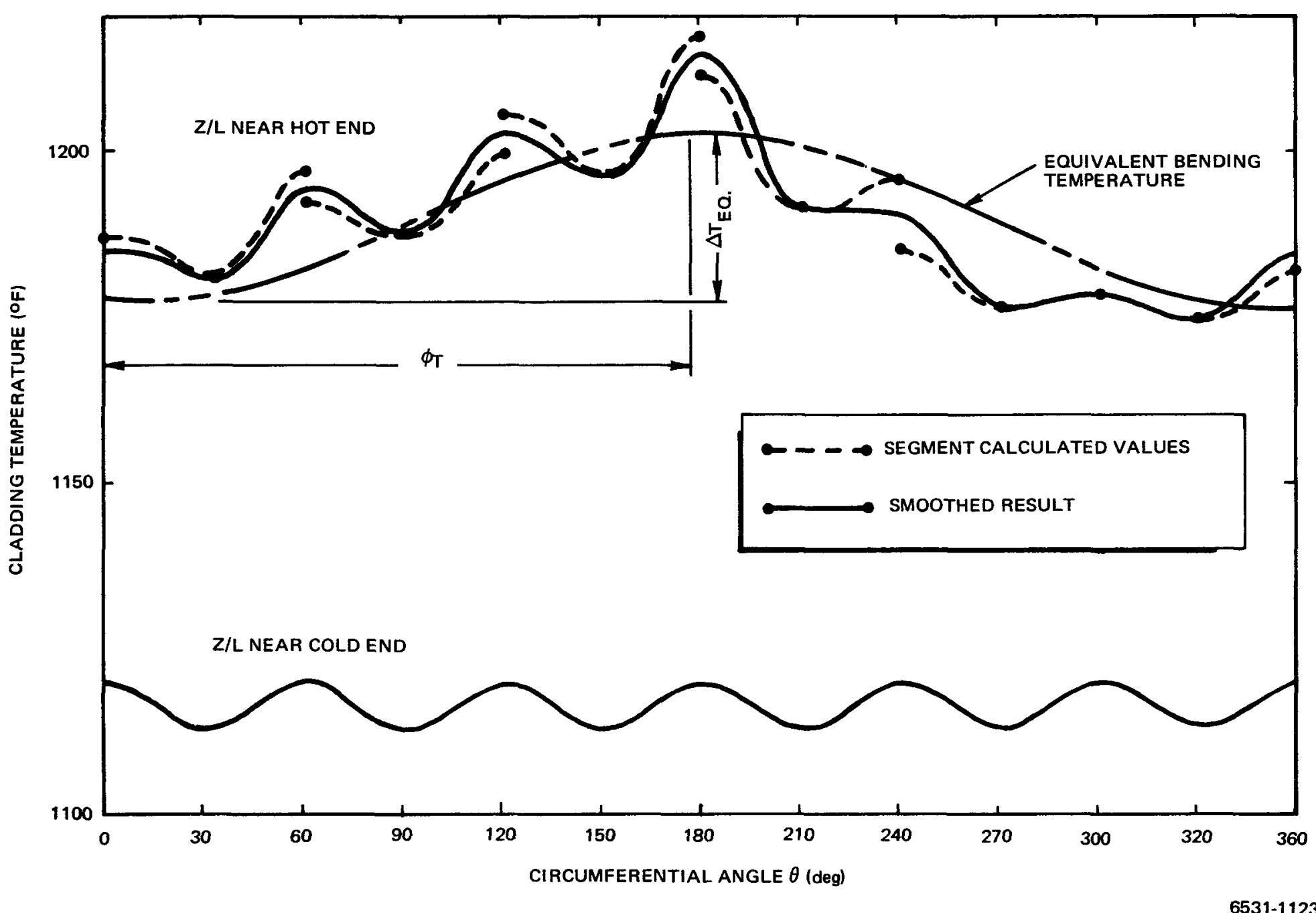

Figure 11. Typical Clad Temperature Profile 


\section{G. FORCE BALANCE}

To calculate the core thermal environment it is necessary to know the individual element configurations since this governs channel geometry and finally flow distribution. Conversely, element geometry cannot be calculated without knowledge of the thermal environment which determines element deflections. As a result, an iterative procedure is used wherein a thermal environment is calculated based on straight cladding, deflections are calculated to suit this environment, a new thermal environment is calculated for the deflected cladding, and the process is repeated to convergence.

Three deflections occur which govern the steady-state fuel element shape: thermal, as manufactured, and contact load. Figure 12 illustrates these deflections and Equations 33 through 42 used for calculation. While a manufacturing bow can have any conceivable shape, the assumption is made that the bow occurs in a single plane and follows a sine wave curvature. Locations of peaks are governed by the TIR shown in Figure 8. The thermal bow is not restricted to a single plane and is calculated by a numerical integration procedure as shown in Figure 12. Basically, this is the solution of:

$$
T=\int_{0}^{L} \frac{M_{t_{i} m_{i} d l}}{E I}
$$

where

$$
\mathrm{M}_{\mathrm{t}_{\mathrm{i}}}=\frac{\pi}{2} \mathrm{E} \alpha \mathrm{Tt \textrm {t } ^ { 2 }}
$$

and

$$
m_{i}=\frac{x_{i}}{L}\left(L-x_{i}\right)
$$

with a correction added to account for the fact that the incremental length is large since only 13 points are calculated along the element. Reference 11 details the correction method used. Because this analysis is only valid for bending in a single plane, the $x-y$ components of temperature effects are calculated and the resultant of the two is the total thermal deflection.

$$
\text { AI-AEC- } 13065
$$


$M_{x_{i}}=\frac{\Delta T_{i} a}{2 r} \sin \phi_{i}$

$M_{y_{i}}=\frac{\Delta T_{i} a}{2 r} \cos \phi_{i}$

...(33)

$T D_{i+1}=\frac{\left(M_{i}+M_{i+1}\right)}{\left(T D_{1}=0\right)}\left(\frac{x_{i+1}-x_{i}}{2}\right)$

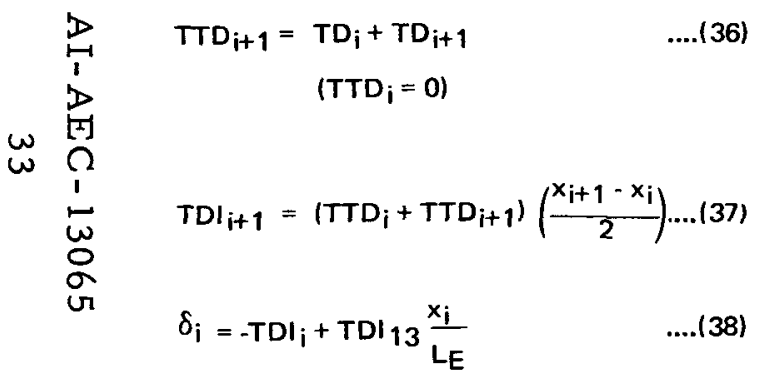

NOTE: $\delta_{T}$ IS THE RESULTANT VECTOR OF $\delta_{x_{i}}$ AND $\delta_{y_{i}}$

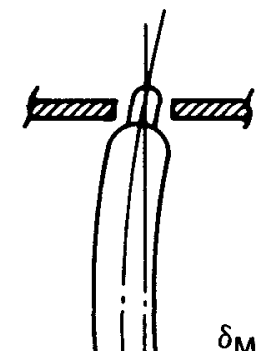

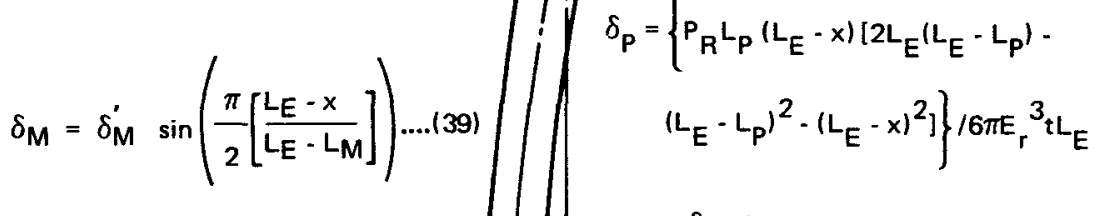

$$
\text { L }
$$

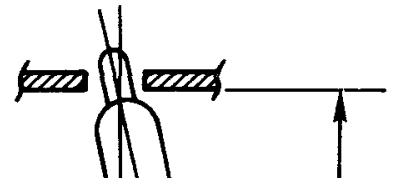

$\delta_{M}=\delta_{M}^{\prime} \sin \left(\frac{\pi}{2} \frac{x}{L_{M}}\right)$

$+\delta_{H^{x / L}}$
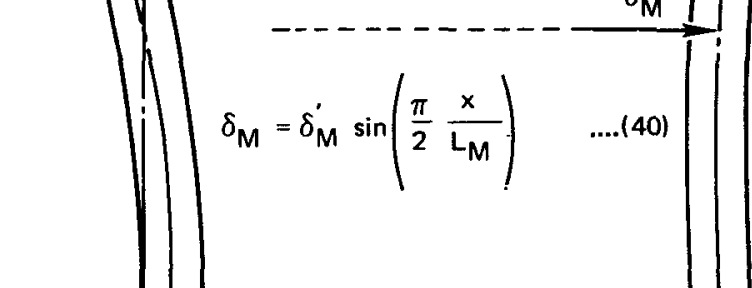

$T$
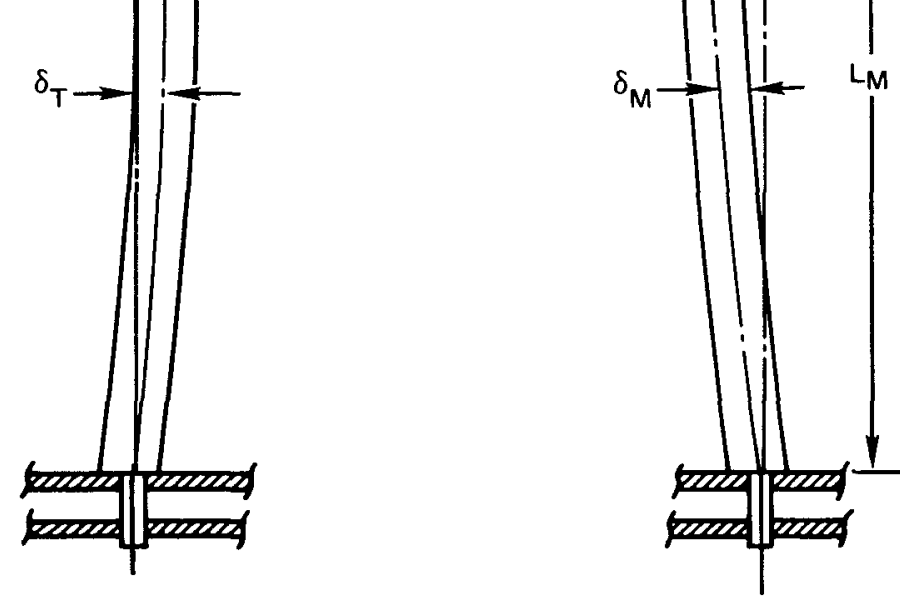

$+\delta_{H \times / L_{E}}$

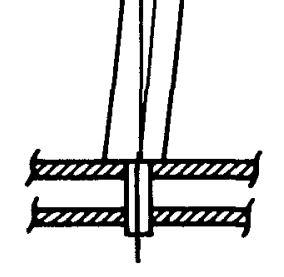

NOTE: DEFLECTIONS GREATLY EXAGGERATED FOR CLARITY 
Deflection resulting from load is calculated as a simple beam. The program assumes that contact is limited to a single plane at elevation $\mathrm{L}_{\mathrm{p}}$. Generally speaking, with a three-fin configuration and as suming undercut fins, except in the contact area, contact could occur at either of two planes. However, for the relatively small fin pitch ( $\sim 5$ in.) used for SNAP reactors, the deviation from a point halfway between is $\pm 0.5 \mathrm{in}$. The effect on deflection and bending stress in an element 15 to 20 in. long is negligible.

Note that the element is pinned at the cold end but can be free to translate within limits at the hot end. This feature was incorporated in the design to minimize loading. As a result, the calculational procedure is complicated by the fact that "load" deflections are possible without loads.

Figure 13 shows the force and combined deflection model used by the code. All calculations are made at the contact plane. The resultant of the thermal and manufacturing bows is calculated for each element. From this, the sector components of the bow are calculated. Because the maximum possible movement of an element is extremely small compared to the element diameter, calculations are based on the assumption that all contact is made on the common centerline of the two elements in contact. The element spring constant is calculated by:

$$
k_{s}=\frac{3 E I L}{L_{p}^{2}\left(L-L_{p}\right)^{2}}
$$

Knowing the clearance between fin and element, $\mathrm{S}_{\mathrm{f}}$ :

$$
P_{i}=\left(\delta_{n}-\delta_{i}-s_{f}\right) \frac{k_{s}{ }_{i}^{k} s_{n}}{k_{s_{i}}+k_{s_{n}}} .
$$

If the force is negative it is set equal to 0 . The positive forces are incrementally reduced and summed to attain convergence of the iteration. The resultant of the six summed forces is calculated permitting calculation of the mechanical deflection by Equations 41 or 42 . The resultant of free and mechanical bow is then computed to permit the next load calculation. The iteration is continued until the incremental force is negligible (less than $1 \%$ ). 


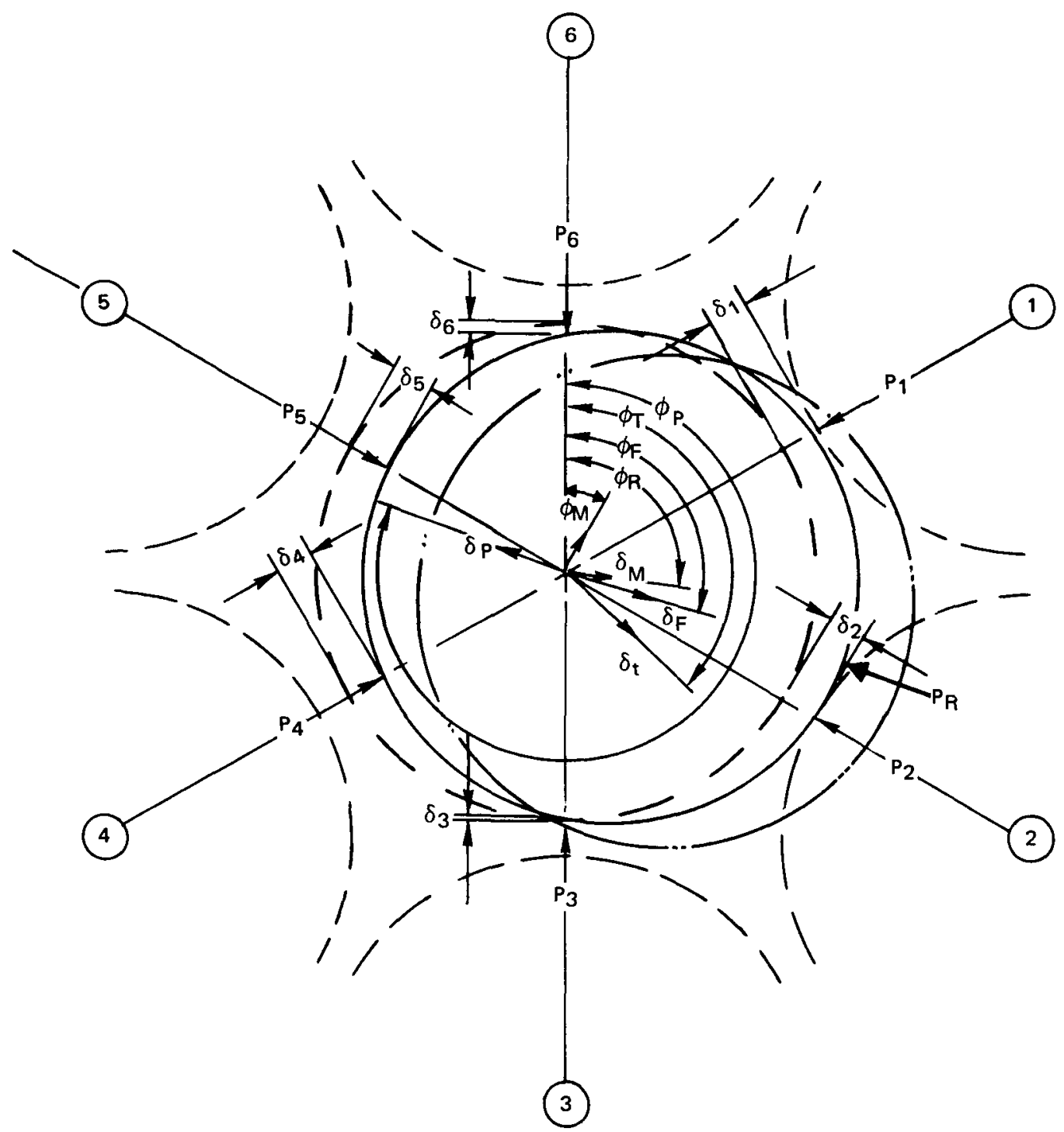

LEGEND

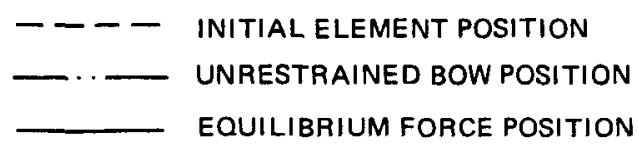

NOTE: EXAMPLE ASSUMES ADJACENT ELEMENTS IMMOBILE, DEFLECTIONS EXAGGERATED FOR CLARITY

Figure 13. Element Force and Deflection Model 
When the force balance convergence is complete, element stresses are computed at each contact point $\mathrm{n}$ as follows:

Bending:

$$
\sigma_{B_{n}}=\frac{P_{R} L_{P}\left(L-L_{p}\right) \cos \left(60 n-\varphi_{p}\right)}{\pi L r^{2} t}
$$

$6 \theta:$

$$
\sigma_{6 \theta_{n}}=-E \alpha\left(T_{c 1}-\bar{T}_{c 1}-T_{B}\right)
$$

Total:

$$
\sigma_{\text {tot }}=\sigma_{B_{n}}+\sigma_{6 \theta_{n}}
$$

Hoop:

$$
\sigma_{\mathrm{H}}=\mathrm{Pk}_{\mathrm{H}}
$$

Axial:

$$
\sigma_{\mathrm{A}}=\mathrm{Pk}_{\mathrm{A}}
$$

Equivalent:

$$
\begin{aligned}
& \sigma_{E Q_{n}}=\operatorname{MAX}\left\{\left[\sigma_{\mathrm{H}}-\mu\left(\sigma_{\mathrm{A}}+\sigma_{\text {tot }}\right)\right],\left(\sigma_{\mathrm{tot}}+\sigma_{\mathrm{A}}-\mu \sigma_{\mathrm{H}}\right)\right\} \\
& \mathrm{MS}=\frac{\sigma_{\mathrm{EQ}}}{\sigma_{\mathrm{ALL}}}-1
\end{aligned}
$$

Normally, the allowable stress is governed by the barrier and is the stress at which the onset of gross hydrogen leakage occurs.

H. CALCULATIONAL INTERFACING

Figure 14 is a simplified flow diagram of the GEOM code. Basically there are three nested loops as shown. Each inner loop must converge before the outer loop is entered. Thus the radial loop must converge 11 times for each axial and mechanical loop convergence. The major subroutines used in the 


\section{$\bullet$}

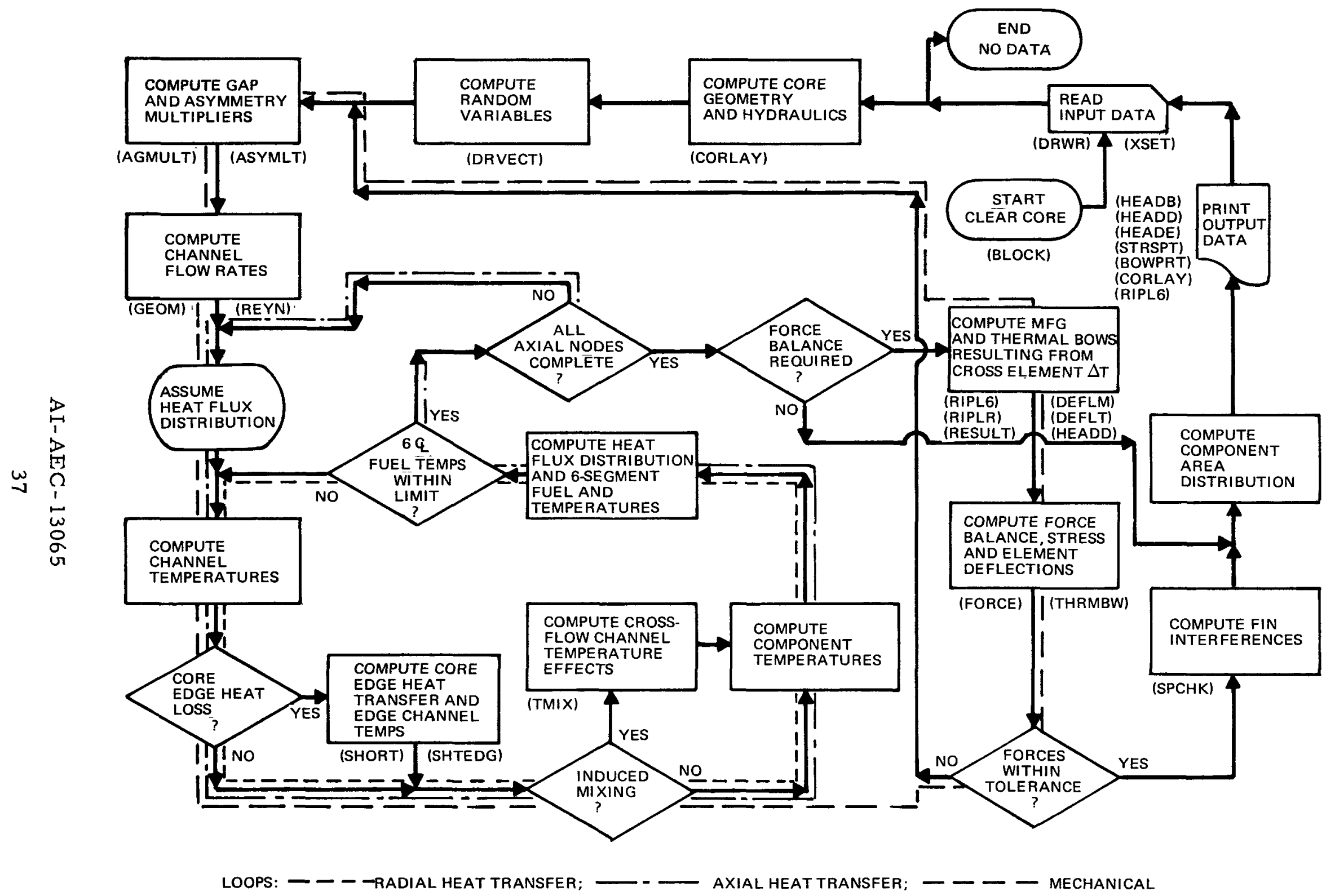

Figure 14. Program Flow Diagram 
program are noted by (DRWR). If no notation is given, the calculation is performed by the main program. Table 2 lists the subroutines used by the program by name and function. Details of special routines are given in the next section.

TABLE 2

LIST OF SUBROUTINES

\begin{tabular}{|c|c|}
\hline Name & Function \\
\hline AGMLT & Computes gap and channel area multipliers \\
\hline ASYMLT & Computes a random array of asymmetry multipliers \\
\hline BLOCK & Zeroes out and builds data into labeled common \\
\hline BOWPRT & Prints magnitude and direction of bow and its components \\
\hline CHNLOC & $\begin{array}{l}\text { Computes identification of elements and channels for an } \\
\text { input channel number }\end{array}$ \\
\hline CORLAY & Computes core dimensions and average hydraulic data \\
\hline DEFLM & Computes manufacturing bow at nodal points \\
\hline DEFLT & Computes thermal bow at nodal points \\
\hline DRVECT & Computes random fuel element dimensional variables \\
\hline DRWR & Data input read and write \\
\hline FORCE & Computes core force balance \\
\hline GAPCND & Computes mixed gas thermal conductivity \\
\hline GAUSYD & Solves simultaneous linear equations \\
\hline HEADB & Prints core thermal and hydraulic data \\
\hline HEADD & Computes and prints equivalent cross element $\Delta \mathrm{T}^{\prime} \mathrm{s}$ \\
\hline HEADE & Prints details of core edge heat transfer \\
\hline HFILM & Computes coolant film coefficient \\
\hline HYPT & Computes maximum value of an input tabular curve \\
\hline NLERR & Dumps labeled common on program error \\
\hline
\end{tabular}


TABLE 2 (Continued)

LIST OF SUBROUTINES

\begin{tabular}{|c|c|}
\hline Name & Function \\
\hline NLEST & Performs method of chords iteration calculations \\
\hline NLTRP & Tabular data interpolation \\
\hline PAR & Solves a second-degree polynomial for a three-point input \\
\hline PINLOC & $\begin{array}{l}\text { Computes identification of elements and channels for a } \\
\text { given element }\end{array}$ \\
\hline POD & Computes an equivalent $P / D$ ratio for edge channels \\
\hline POLY4 & Four-point curve fit (used by NLTRP) \\
\hline RESULT & $\begin{array}{l}\text { Calculates magnitude and direction of resultant of two } \\
\text { vectors }\end{array}$ \\
\hline REYN & $\begin{array}{l}\text { Calculates Reynolds number for laminar/turbulent } \\
\text { interface }\end{array}$ \\
\hline RIPL6, RIPLR & Computes and prints $6 \theta$ ripple data \\
\hline SHTEDG & Computes core edge geometry \\
\hline SHORT & Computes core edge heat transfer \\
\hline SPCHK & Computes element-element clearance at each node \\
\hline STRSPT & Prints force and stress data for core \\
\hline THRMBW & Computes element deflection and stresses \\
\hline TMIX & Computes cross flow and resultant coolant temperatures \\
\hline$X M F$ & Computes mixing rate \\
\hline XSET & Sets arrays equal to input single value \\
\hline YFF & Computes $\mathrm{Y}$ factor for hydraulic calculations \\
\hline
\end{tabular}




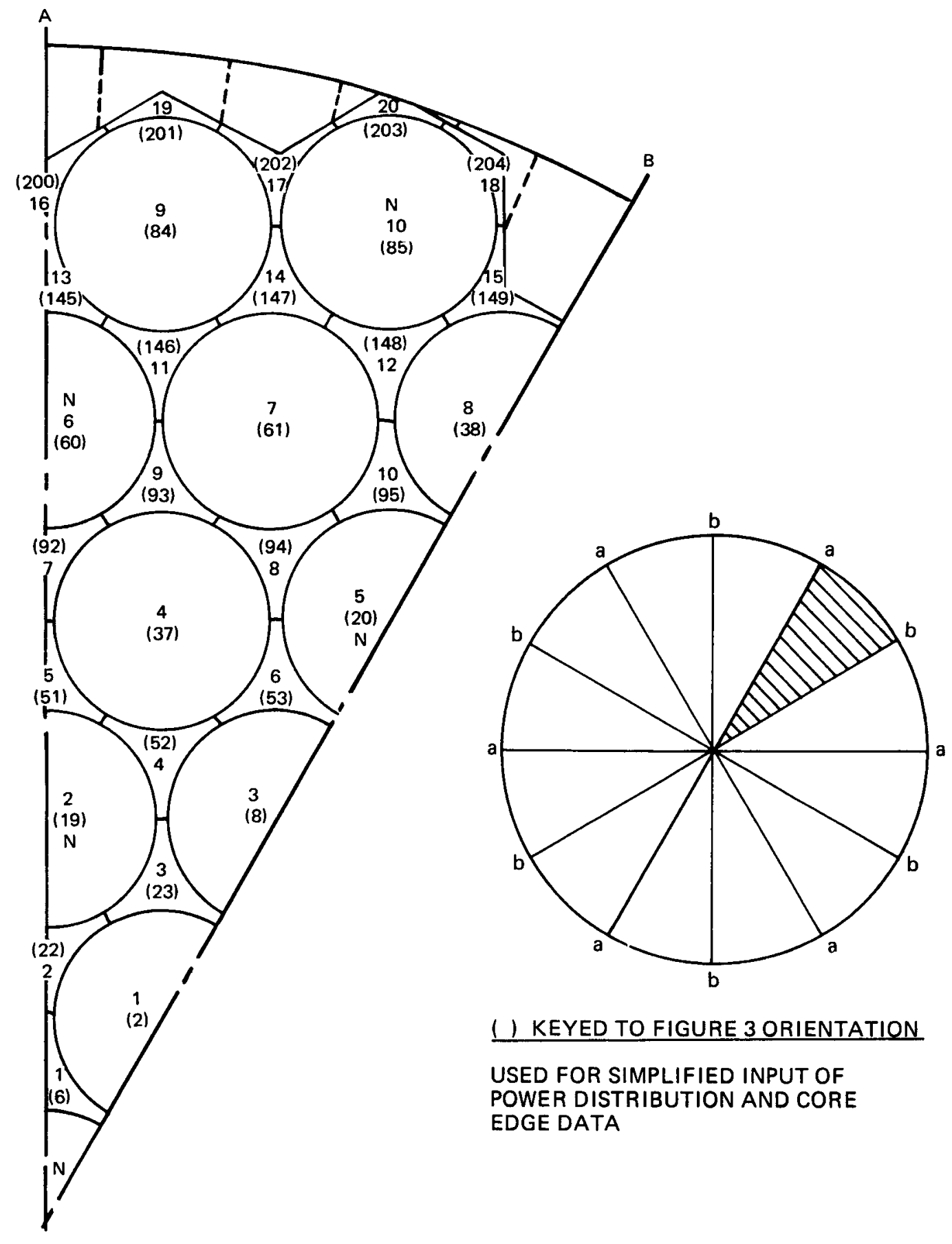

6531-1127

Figure 15. 30-Degree Repeating Sector 


\section{PROGRAMMING TECHNIQUES}

Because of the scope of the program, the amount of data handled is massive. To minimize the effort necessary to run the program, specialized techniques have been used and are described in this section. Internal programming techniques are also described.

\section{A. 30-DEGREE SECTOR SYMMETRY}

Many variables are symmetric and as a result are repeated 12 times in the cross-sectional model. Therefore a repeating 30-degree sector (shown in Figure 15) is used in these instances. Data input is then permissible for this sector only when symmetric or for the full 360-degree sector if asymmetric. This technique is also used internally to reduce required data storage by using the 30-degree sector for bookkeeping purposes.

\section{B. BUILT-IN DATA}

Many of the input variables used are really quasi-constants in that data changes only as a result of new experimental results, material changes, etc. Therefore, as much data as possible is built into the program to minimize required input and to reduce the possibility of error. In most cases, this builtin data may be overridden simply by entering the desired value in the input string.

\section{AREA AND GAP MULTIPLIERS}

Channel area and gas gap multipliers are applied to nominal symmetric values to attain the geometric effect of bowed clad and offset fuel. This data may either be input or calculated internally. Figure 16 shows the models used for calculation. In the case of the channel, the area changes resulting from each of the three elements surrounding the channel are summed to determine the total change. The gap multipliers are determined by comparing the area in each sector to that of an equivalent $1 / 6$ annulus to determine the average gap width for the sector. When using the force balance, area multiplier calculation is automatic. Gap multiplier calculation is always optional. 

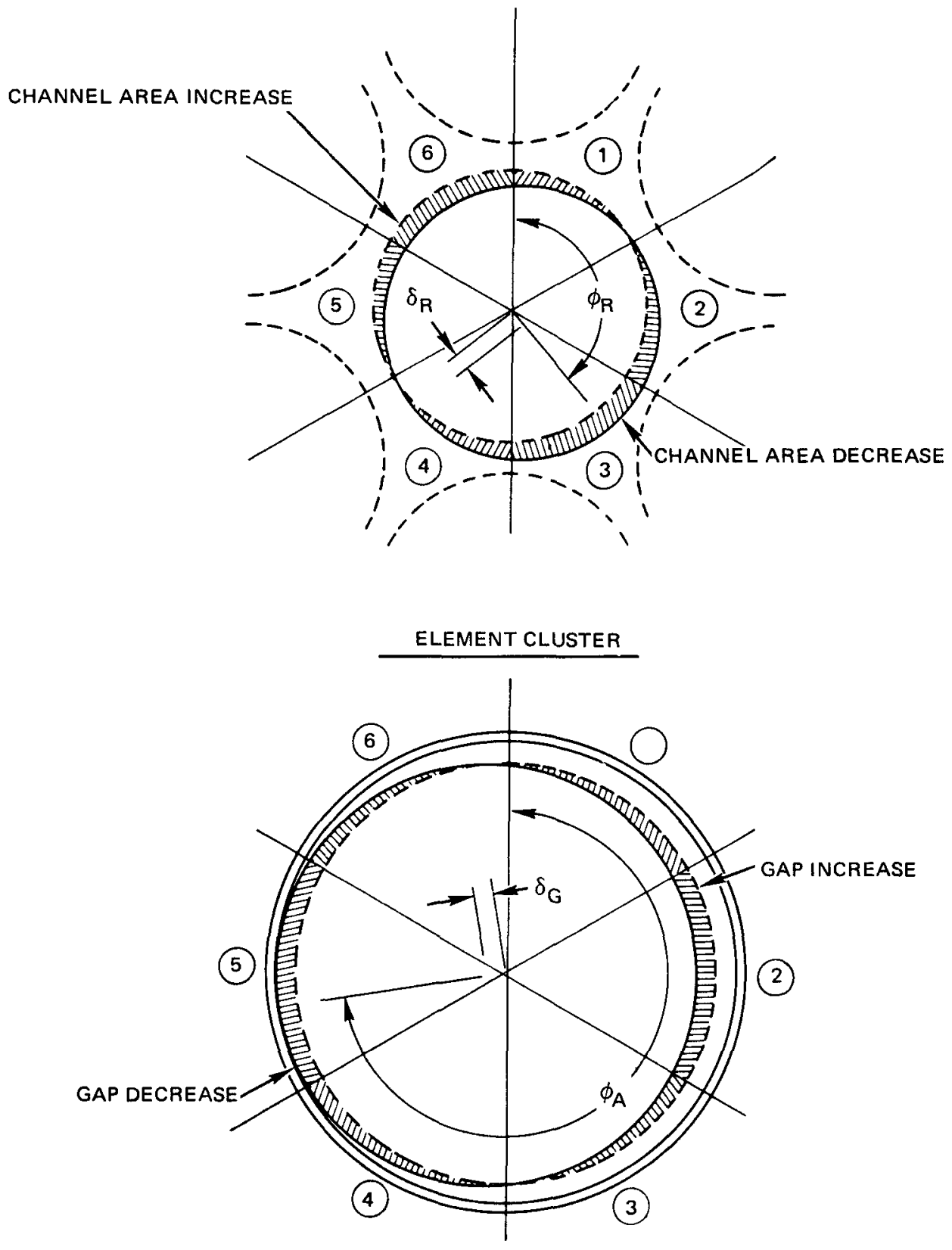

FUEL ASYMMETRY

$6531-1128$

Figure 16. Cluster and Asymmetry Models 


\section{ITERATIVE TECHNIQUES}

Four major iterative techniques are used:

1) Simple substitution of computed value for assumed value (or average of computed and assumed)

2) Newton-Rapheson

3) Method of chords

4) Incremental change of variable.

Method (1) is self-explanatory and method (4) was described for the force balance. Method (2) requires a single equation in terms of $\mathrm{x}$ so that the solution is $f(x)=0$. As suming a value of $x_{0}$ then:

$$
\begin{aligned}
F & =f\left(x_{0}\right) \\
D & =f\left(x_{0}\right) \\
x_{n} & =x_{0}-F / D
\end{aligned}
$$

If $\left|x_{0} / x_{n}-1\right| \leq$ tolerance, convergence has been met, otherwise $x_{0}=x_{n}$ and the procedure is repeated.

Method (3) can be used to solve a large set of equations with a common variable $\mathrm{x}$ which can result in two solutions $\mathrm{y}$ and $\mathrm{z}$. Two initial assumptions are made for $\mathrm{x}$ yielding two points $\mathrm{x}_{1}, \mathrm{y}_{1}-\mathrm{z}_{1}$ and $\mathrm{x}_{2}, \mathrm{y}_{2}-\mathrm{z}_{2}$, resulting in a straight line equation. $x_{3}$ is then calculated as the intersection of this line and $y-z=0$. A third point is then calculated $x_{3}, y_{3}-z_{3}$ and the procedure is repeated using the current point $x_{i}, y_{i}-z_{i}$ and the last calculated point $x_{i-1}$, $y_{i-1}-z_{i-1}$ to obtain the chord. Iteration is continued until $\left|y_{i} / z_{i}-1\right| \leq$ tolerance.

\section{E. TABLE LOOK UP}

The method used for tabular data is based on a routine which fits three mutually tangent polynomials to four points - a second degree between points 1 and 2 , a third degree between points 2 and 3, and a second degree between points 3 and 4 . The use of this four-point approach rather than the usual threepoint parabolic fit permits greater accuracy for skewed curves and also reduces 
the number of points required for highly fluctuating curves. The tabular array is searched to locate two points on either side of the input value for solution. Extrapolation is conducted if the point input is at either end of the tabular array. Three-point input curves are treated as parabolas and two-point input as a straight line.

\section{F. SIMULTANEOUS EQUATION SOLUTION}

Solution of mixing and edge heat transfer involves a large set of simultaneous equations. If a square matrix were used wherein all values were zero except a few along the diagonal, the cost in required core storage would be prohibitive. Therefore, an iterative Gauss-Seidel method of solution has been used. This is accomplished by setting up a control array of index values to insure proper use of the results. The method is described in Reference 12.

\section{G. PROGRAM STRUCTURE}

The code is written in Fortran $H$ for IBM System 360.

To minimize core storage requirements it was necessary to set the program up in an overlay structure as shown in Figure 17. Both decimal and hexadecimal levels of segment origin and end are given. The main program and labeled common, which must reside in the root segment, require $342 \mathrm{~K}_{10}$ storage bytes. The segment lengths are very close to being equal, thus any further reduction could only be accomplished by using more segments and/or relocating routines now in the root segment. However, since computer time is expended in shifting segments for overlay it is desirable to minimize these shifts, thus a balance is necessary to have the lowest total operational cost. The structure used is based on these criteria. 


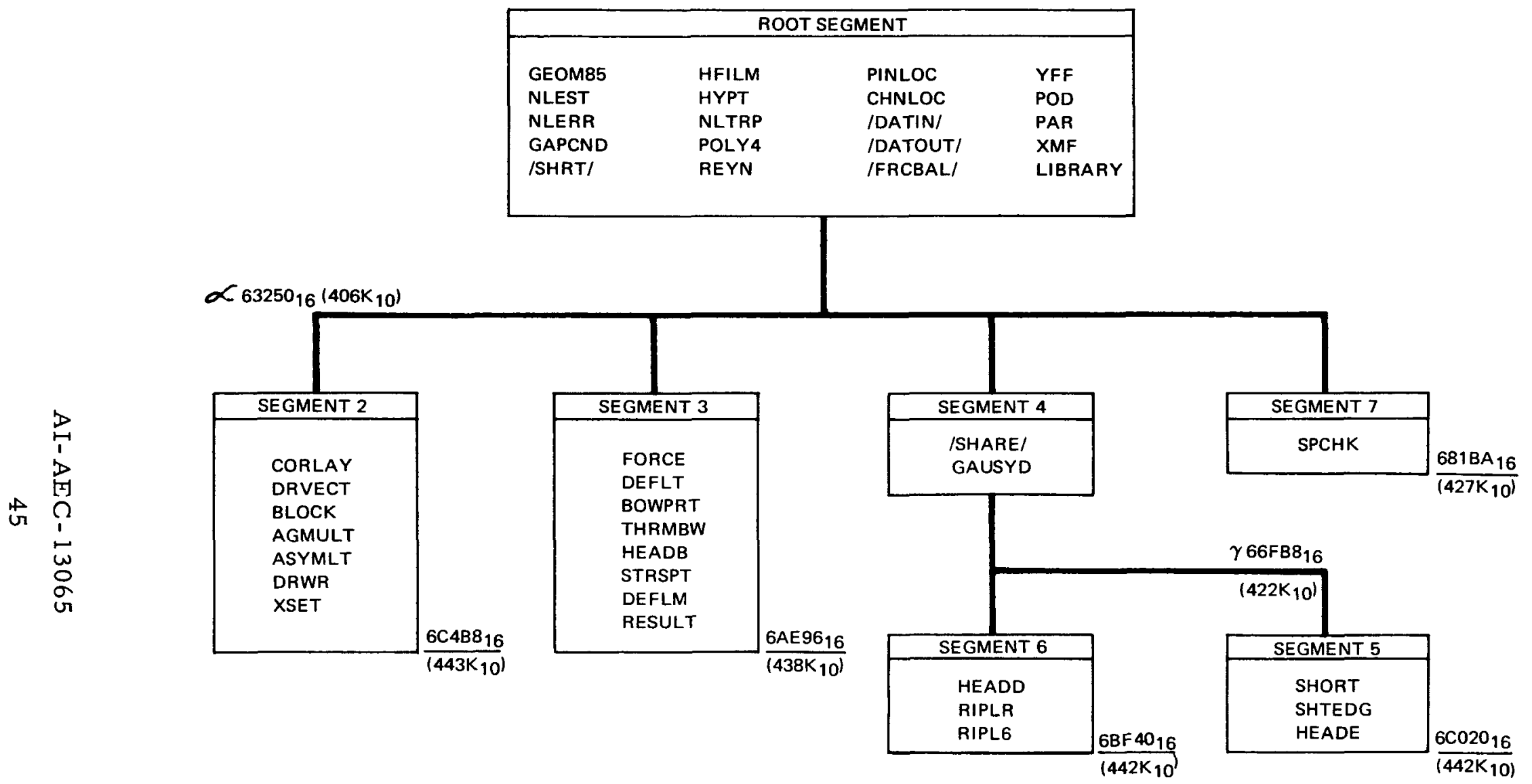

Figure 17. Program Overlay Structure 
BLANK

$\bullet$ 


\section{PROGRAM USE}

While every effort has been made to simplify input to the GEOM code, it is recommended that only personnel very knowledgeable in the workings of a liquid metal $\mathrm{ZrH}$ core set up runconditions and analyze the results. While the actual mechanics of using the code are fairly simple, runs are costly because of the extreme complexity of the code.

Tables 3 through 6 describe the four major labeled common blocks used in the program. /DATIN/ is the primary input block, however, certain arrays in /DATOUT/ may be either input or computed. The following sections describe the use of the se common blocks.

\section{A. INPUT DATA REQUIREMENTS}

The majority of the data in Table 3 is self-explanatory. Those items marked (FLAG) are explained in Section B-Program Options. Those that might not be fully understood are described as follows by location and symbol:

(14) SLOP - This value is a design item wherein elements are allowed some freedom for thermal bow which decreases contact force.

(83-86) EDGM - The edge areas (sans fins) are computed from drawings and ratioed to a full tri-cusp to get these values. The area multipliers are in the order of:

1) Two finned elements (16)

2) One finned, one neutral element $(15,17)$

3) One finned element (19)

4) One neutral element (18,20) (See Figure 15)

(111-176) PWIR

(12407-12472) FFP - These data refer to a ring concept for the internal reflector wherein stagnant $\mathrm{NaK}$ was contained in a set of steel rings. Some flow was possible, therefore the wetted perimeter was necessary to calculate flow distribution.

AI- AEC- 13065 
TABLE 3

/DATIN/ LABELED COMMON DESCRIPTION

$(12,500)$

(Sheet 1 of 4 )

\begin{tabular}{|c|c|c|c|}
\hline Symbol & Data & Dimension & Location \\
\hline PCOR & Core Power, kwt & & I \\
\hline TIN & Coolant Inlet Temperature, ${ }^{\circ} \mathrm{F}$ & & 2 \\
\hline WDOT & Coolant Flow Rate, Ib/hr & & 3 \\
\hline$C P:$ & Coolant Specific Heat, Btu/1b (0.21) & & 4 \\
\hline $\mathrm{XMU} *$ & Coolant Viscosity, $1 \mathrm{~b} / \mathrm{ft}-\mathrm{hr}(0.39)$ & & 5 \\
\hline RHO & Coolant Density, $1 \mathrm{~b} / \mathrm{ft}^{3}(45)$ & & 6 \\
\hline $\mathrm{XKO} \mathrm{O}^{*}$ & Coolant Thermal Conductivity, Btu $/ \mathrm{hr}-\mathrm{ft}-{ }^{\circ} \mathrm{F}$ (14.9) & & 7 \\
\hline DPEXP: & Friction Factor Re Exponent (-3.273) & & 8 \\
\hline $\mathrm{XKFF}$ & Friction Factor Constant (238) & & 9 \\
\hline ENFP' & Number of Fins/Element (3) & & 10 \\
\hline ENP & Number of Active Elements (85) & & 11 \\
\hline AGRD l & Inlet Grid Plate Area, in. ${ }^{2}$ & & 12 \\
\hline AGRD2 & Outlet Grid Plate Area, in. ${ }^{2}$ & & 13 \\
\hline SLOP & Allowable Spacing Decrease, in. & & 14 \\
\hline DPIN & Nominal Cladding Outsıde Diameter, in. & & 15 \\
\hline TRPTCH & Triangular Pitch, in. & & 16 \\
\hline FNWD & Fin Width, in. & & 17 \\
\hline FNHT & Fin Height, in. & & 18 \\
\hline$X L$ & Active Fuel Length, ft & & 19 \\
\hline XLCC & Channel Length, in. & & 20 \\
\hline TCL & Cladding Thickness, in. (nominal) & & 21 \\
\hline TGL & Barrier Thickness, in. & & 22 \\
\hline DFUEL & Fuel Diameter, in. (constant for all elements) & & 23 \\
\hline XMIX & FLAG - Invokes Mixing Calculations $>0$ & & 24 \\
\hline SHTFLG & FLAG - Invokes Short Calculations $\neq 0$ & & 25 \\
\hline $\mathrm{XKCL}$ * & Cladding Thermal Conductivity, Btu $/ \mathrm{hr}-\mathrm{ft}-{ }^{\circ} \mathrm{F}$ (12.5) & & 26 \\
\hline XKGL $*$ & Barrier Thermal Conductivity, Btu $/ \mathrm{hr}-\mathrm{ft}-{ }^{\circ} \mathrm{F}$ (1) & & 27 \\
\hline $\mathrm{XKF} *$ & Fuel Thermal Conductivity, Btu $/ \mathrm{hr}-\mathrm{ft}-{ }^{\circ} \mathrm{F}$ (11.5) & & 28 \\
\hline FLAG & FLAG - Bypasses Spacing Calculation $>0$ & & 29 \\
\hline $\mathrm{XBP}$ & Bypass Flow Fraction & & 30 \\
\hline TPV & Pressure Vessel Thickness, in. & & 31 \\
\hline TBP & Bypass Thickness, in. & & 32 \\
\hline TLIN & Liner Thickness, in. & & 33 \\
\hline RLIN* & Liner/Reflector Resistance, Btu/hr $-\mathrm{ft}^{2}-^{\circ} \mathrm{F}(1000)$ & & 34 \\
\hline HNAKI* & Bypass/Liner Resistance, Btu/hr-ft ${ }^{2}-{ }^{\circ} \mathrm{F}(1000)$ & & 35 \\
\hline HNAKO* & Bypass/Vessel Resistance, Btu/hr-ft ${ }^{2}{ }^{\circ} \mathrm{F}(1000)$ & & 36 \\
\hline PTCHAX & Axial Fin Pitch, in. & & 37 \\
\hline ACTIDL* & Ratio of Actual/Computed Mixing (not used) & & 38 \\
\hline PWFLG & FLAG - Bypasses Laminar Bypass Calculation $>0$ & & 39 \\
\hline $\left.\begin{array}{l}\mathrm{AF} * \\
\mathrm{BF} *\end{array}\right\}$ & Fuel Expansion $\alpha_{F}=a+b \overline{\mathrm{T}}_{F} \begin{array}{r}\left(7.232 \times 10^{-6}\right) \\
\left(-0.34 \times 10^{-9}\right)\end{array}$ & & $\begin{array}{l}40 \\
41\end{array}$ \\
\hline$A C * 7$ & Cladding Expansion $\alpha_{c}=a+b \bar{T}_{c}\left(7.3525 \times 10^{-6}\right)$ & & 42 \\
\hline $\mathrm{BC} * \mathrm{~J}$ & $\left(1.0375 \times 10^{-9}\right)$ & & 43 \\
\hline
\end{tabular}


TABLE 3

/DATIN/ LABELED COMMON DESCRIPTION (Sheet 2 of 4 )

\begin{tabular}{|c|c|c|c|}
\hline Symbol & Data & Dimension & Location \\
\hline SPCFLG & FLAG - Calculates Spacing Only $>0$ & & 44 \\
\hline DEBUG & FLAG - Prints Intermediate Calculations $>0$ & & 45 \\
\hline ZOLFLG* & FLAG - Uses Input $Z / L>0(1)$ & & 46 \\
\hline DATFLG & FLAG - Reads Comment Cards $>0$ & & 47 \\
\hline RIPL. & FLAG - Controls $6 \theta$ Ripple Output $>0$ (1) & & 48 \\
\hline PWRFLG* & FLAG - Sets Number of Power Iterations $>0$ & & 49 \\
\hline XMLTFL & FLAG - Sets AM \& TGM $=1>0$ & & 50 \\
\hline CMPMLT & FLAG - Computes AM \& TGM $>0$ & & 51 \\
\hline BZSET & FLAG - Sets BOWZOL $=$ I st value $>0$ & & 52 \\
\hline ASSET & FLAG - Sets ASYZOL - 1st value $>0$ & & 53 \\
\hline DRREST & FLAG - Resets ASYDIR \& BOWDIR $=0$ & & 54 \\
\hline $\mathrm{XKV}^{*}$ & $\begin{array}{l}\text { Pressure Vessel Thermal Conductivity, } \\
\text { Btu/hr-ft- }{ }^{\circ} \mathrm{F}(12.9)\end{array}$ & & 55 \\
\hline $\mathrm{XKB} *$ & Bypass Thermal Conductivity, Btu $/ \mathrm{hr}-\mathrm{ft}-{ }^{\circ} \mathrm{F}$ (14.9) & & 56 \\
\hline$X K L *$ & Liner Thermal Conductivity, Btu $/ \mathrm{hr}-\mathrm{ft}-^{\circ} \mathrm{F}$ (12.9) & & 57 \\
\hline EPSF* & $\begin{array}{l}\text { Equivalent Fuel/Glass Emissivity, } \\
\epsilon=1 /\left(1 / \epsilon_{\mathrm{G}}+1 / \epsilon_{\mathrm{F}}-1\right)(0.474)\end{array}$ & & 58 \\
\hline PHE* & Helium Loadıng Pressure, psia (3) & & 59 \\
\hline XLCND & Conductive Channel-Channel Path Length, in. & & 60 \\
\hline$X W C N D$ & Conductive Channel-Channel Path Width, in. & & 61 \\
\hline ECLD & Cladding Elastıc Modulus, psi (FLAG) & & 62 \\
\hline$A L F C L D$ & Cladding Instantaneous Expansion, in. $/ 1 \mathrm{n} .-^{\circ} \mathrm{F}$ & & 63 \\
\hline $\mathrm{ACD}$ & $\eta / \mathrm{m}=\mathrm{a}(\mathrm{CD})+\mathrm{b}$ (not used) & & 64 \\
\hline $\mathrm{BCD} *$ & & & 65 \\
\hline$\left.A X^{\prime}\right)$ & & & 66 \\
\hline $\mathrm{BX}$ & $h_{x}=h_{10}\left[l+\left(\frac{a}{P / D-1}\right)^{D}\left(c+\frac{d}{t c}\right)\right]$ (Eq. 22) & & 67 \\
\hline $\mathrm{CX}$ & & & 68 \\
\hline $\mathrm{DX}$ & & & 69 \\
\hline $\mathrm{ACF}$ & & & 70 \\
\hline $\mathrm{BCF}^{\sim}$ & $h_{m}=h_{x}\left[a+b x_{m}+c x_{m}(P / D-1)\right] \quad(E q .23)$ & & 71 \\
\hline $\mathrm{CCF}$ & a & & 72 \\
\hline$A R^{\prime}$ & $\Delta t_{6 \theta}=\left(\frac{t c}{0.032}\right)^{a}(b+c h) P$ & & 73 \\
\hline$B R \times$ & & & 74 \\
\hline$C R *$ & & & 75 \\
\hline BOWM & Maximum Manufacturing Bow, in. & & 76 \\
\hline ENVI: & Inlet Grid Velocity Head Coefficient (1) & & 77 \\
\hline ENVR* & Outlet Grid Velocity Head Coefficient (0.5) & & 78 \\
\hline ELI & Inlet Grid - Fuel Length, in. & & 79 \\
\hline $\mathrm{AFC} *$ & Fuel Accommodation Coefficient $(0.9)$ & & 80 \\
\hline AGC" & Barrier Accommodation Coefficient (0.3) & & 81 \\
\hline RMIN & Liner Inside Radius, in. (output) & & 82 \\
\hline $\operatorname{EDGM}(1) *)$ & $(0.715)$ & & 83 \\
\hline $\operatorname{EDGM}(2) *$ & Edge Channel Area Multupliers (Nominal) (0.65) & & 84 \\
\hline $\operatorname{EDGM}(3) *$ & $(0.425)$ & & 85 \\
\hline $\operatorname{EDGM}(4) *$ & $(0.235)$ & & 86 \\
\hline
\end{tabular}


TABLE 3

/DATIN/ LABELED COMMON DESCRIPTION (Sheet 3 of 4 )

\begin{tabular}{|c|c|c|c|}
\hline Symbol & Data & Dimension & Location \\
\hline AFCBR & Average Channel Area, in. ${ }^{2}$ & & 87 \\
\hline PWCBR & Average Channel Wetted Perimeter, in. & & 88 \\
\hline $\mathrm{DH}$ & Core Hydraulic, Diameter (in.) & & 89 \\
\hline $\mathrm{VCO} 2$ & Average Core Velocity, fps (output) & & 90 \\
\hline REN & Average Core Reynolds Number & & 91 \\
\hline YBAR & Average Core Y Factor & & 92 \\
\hline $\mathrm{zz}$ & Average Core Z Factor & & 93 \\
\hline $\mathrm{FF}$ & Average Core Friction Factor & & 94 \\
\hline BWLMT* & Bow Iteration Limit (F LAG) (3) & & 95 \\
\hline \multirow[t]{5}{*}{ HEL } & Radial Hot End Looseness, in. & & 96 \\
\hline & & & 97 \\
\hline & & & 98 \\
\hline & & & 99 \\
\hline & & & 100 \\
\hline VEC & FLAG - Controls Random Multiplier Calculations & & 101 \\
\hline CTACT & Distance Cold End to Contact Plane, in. & & 102 \\
\hline DTOUT & FLAG - Reads In/DATOUT/Data > 0 & & 103 \\
\hline BWOPT & FLAG - Manufacturing Bow Option & & 104 \\
\hline ELTIR1 & $\begin{array}{l}\text { Distance Cold End to Lower Manufacturing Bow } \\
\text { Limit, in. }\end{array}$ & & 105 \\
\hline ELTIR2 & $\begin{array}{l}\text { Distance Lower End to Upper Manufacturing Bow } \\
\text { Limit, in. }\end{array}$ & & 106 \\
\hline BWMIN & Minimum Manufacturing Bow Multiplier & & 107 \\
\hline RIPANG & $6 \theta$ Ripple Distortion, deg & & 108 \\
\hline SPRF LG & FLAG - Prints Stress Details for all Elements $>0$ & & 109 \\
\hline ALLOW* & Allowable Cladding Stress, psi (34000) & & 110 \\
\hline PWIR & Rigid Ring Channel Perimeter, in. & 66 & $111 / 176$ \\
\hline PWIR 30 & PWIR for $30^{\circ}$ Sector & 6 & $177 / 182$ \\
\hline XKRR $30 *$ & XKRR for $30^{\circ}$ Sector (23) & 6 & \\
\hline XKRC 30* & XKRC for $30^{\circ}$ Sector (23) & 6 & $189 / 194$ \\
\hline FFP30* & FFP for $30^{\circ}$ Sector $(1)$ & 6 & $195 / 200$ \\
\hline TPV30* & TPVO for $30^{\circ}$ Sector $(750)$ & 10,6 & $201 / 260$ \\
\hline PHI30 & PHI for $30^{\circ}$ Sector & 11,11 & $261 / 381$ \\
\hline POR & Gap Pressure $\left(\mathrm{H}_{2}\right)$ vs $r / R_{\psi}$, psia & 15 & $382 / 396$ \\
\hline$A M *$ & Area Multipliers (input or computed) (1) & 11,204 & $597 / 2640$ \\
\hline TGM* & Gap Thickness Multipliers (input or computed) (1) & $11,85,6$ & $2641 / 8250$ \\
\hline ZOL* & $\mathrm{Z} / \mathrm{L}$ Ratio (input or computed) (by $1 / 10$ ) & 11 & $8251 / 8261$ \\
\hline HFINM* & Fin Height Multipliers (vs Z/L) (1) & 11 & $8262 / 8272$ \\
\hline EFFMX* & Mixing Rate Multipliers (vs Z/L) (1) & 11 & $8273 / 8283$ \\
\hline HFTBL* & Nusselt Number vs P/D (See Figure 7) & 35 & $8384 / 8318$ \\
\hline $\mathrm{R} \varnothing \mathrm{DB} \emptyset \mathrm{W}$ & Maximum Element Bow, in. (input or computed) & 85 & $8319 / 8403$ \\
\hline ASYMRD* & $\begin{array}{l}\text { Maximum Euel Asymmetry, Fraction of Gap } \\
\text { (input or computed) (0.9) }\end{array}$ & 85 & $8404 / 8488$ \\
\hline
\end{tabular}


TABLE 3

/DATIN/ LABELED COMMON DESCRIPTION (Sheet 4 of 4 )

\begin{tabular}{|c|c|c|c|}
\hline Symbol & Data & Dimension & Location \\
\hline $\mathrm{B} \emptyset W D I R$ & Bow Direction Angle, deg (input or computed) & 85 & $8489 / 8573$ \\
\hline ASYDIR & Asymmetry Direction Angle, deg (input or computed) & 85 & $8574 / 8658$ \\
\hline ASYZ $\varnothing \mathrm{L}$ & ASYMR $\emptyset D$ Axıal Multıpliers (for Angle and/or Gap) & 11,85 & $8659 / 9593$ \\
\hline $\mathrm{B} \varnothing W Z \varnothing \mathrm{L}$ & $\mathrm{R} \varnothing \mathrm{DB} \varnothing W$ Axial Multipliers (input or computed) & 11,85 & $9594 / 10528$ \\
\hline TPVD & Core Ambient Temperatures, ${ }^{\circ} \mathrm{F}$ & 10,66 & $10529 / 11188$ \\
\hline EPS & $\begin{array}{l}\text { Effective Pressure Vesse1/Ambient } \\
\text { Emissivity }(0.176)\end{array}$ & 66 & $11189 / 11254$ \\
\hline HELMLT & Hot End Looseness Multipliers & 85 & $11255 / 11339$ \\
\hline PHI & Power Factor $\left(\omega_{\mathrm{A}} \varphi_{\mathrm{R}}\right)$ vs $\mathrm{Z} / \mathrm{L}$ and Element & 11,85 & $11340 / 12274$ \\
\hline $\mathrm{XKRR}$ & $\begin{array}{l}\text { Internal Reflector Conductivity (Radial), } \\
\text { Btu } / \mathrm{hr}-\mathrm{ft}-{ }^{\circ} \mathrm{F}\end{array}$ & 66 & $12275 / 12340$ \\
\hline $\mathrm{XKRC}$ & $\begin{array}{l}\text { Internal Reflector Conductivity (Circumferential) } \\
\text { Btu } / \mathrm{hr}-\mathrm{ft}--^{\circ} \mathrm{F}\end{array}$ & 66 & $12341 / 12406$ \\
\hline FFP & Internal Reflector Steel Fraction & 66 & $12407 / 12472$ \\
\hline A.A & $\mathrm{K}_{\mathrm{a}}=\mathrm{at} \mathrm{cl}_{\mathrm{cl}} \mathrm{d}_{\mathrm{cl}}+\mathrm{b}($ Bijlaard Ax1al Multiplıer $)(0.38911)$ & & 12473 \\
\hline $\mathrm{BA}$ & $(+0.1576)$ & & 12474 \\
\hline POIR & Poisson's Ratio (Cladding) (0.3) & & 12475 \\
\hline SPIR" & Internal Reflector Spring Constant, $1 \mathrm{~b} / \mathrm{in} .\left(10^{6}\right)$ & & 12476 \\
\hline SCKFLG & FLAG - Suppresses Spacıng Check $>0$ & & 12477 \\
\hline SEED & Multıplier to Force New Seed for IRNDM & & 13478 \\
\hline $\mathrm{AH}$. & $k_{h}=a t_{c l} d_{c l}+b($ B1jlaard Hoop Multiplier) $(-114286)$ & & 12479 \\
\hline $\mathrm{BH} *$ & $(4259)$ & & 12480 \\
\hline TLID & Cladding ID Tolerance, in. $(0.001)$ & & 12481 \\
\hline TLTH & $\begin{array}{l}\text { Cladding Thickness Tolerance, in. (Finned } \\
\text { Elements) }(0.0015)\end{array}$ & & 12482 \\
\hline TLFH & Fin Height Tolerance, in. (0.001) & & 12483 \\
\hline TLTN & $\begin{array}{l}\text { Cladding Thickness Tolerance (Neutral Elements) } \\
(0.001)\end{array}$ & & 12484 \\
\hline RNASY & FLAG - >0 Computes Random ASYZ $\emptyset \mathrm{L}$ & & 12485 \\
\hline XMASY & FLAG $-1=$ ASYZ $\varnothing$ L on Angle, $2=$ on gap, $3=$ on both (1) & & 12486 \\
\hline ENSLG & Number of Fuel Slugs in Element (5 maximum) (5) & & 12487 \\
\hline$A B C D E$ & $\begin{array}{l}\text { FLAG - Each Digit is Number of } Z / L \text { Points on } \\
\text { Slug (22322) }\end{array}$ & & 12488 \\
\hline FNLR & FLAG - Calls NLERR at End of Run & & 12489 \\
\hline RVRSE & FLAG - Reverses BOWDIR and ASYDIR if $>0$ & & 12490 \\
\hline PRTLAM & FLAG - >0 Prınts Laminar/Turbulent Flow Vectors & & 12491 \\
\hline TФLWAY & $\begin{array}{l}\text { FLAG - Controls } \pm \text { Values of Cladding Tolerance } \\
\text { Not Used }\end{array}$ & $12493 / 12500$ & $\begin{array}{c}12492 \\
12493 / 12500\end{array}$ \\
\hline
\end{tabular}

*Denotes Data Bullt-In ( ) or see text. FLAG - Denotes option control, see text, Sec. V. B. 
TABLE 4

/DATOUT/ LABELED COMMON DESCRIPTION

$(42,500)$

\begin{tabular}{|c|c|c|c|}
\hline Symbol & Data & Dimension & Location \\
\hline NCHAN* & Array Locating Channel to $30^{\circ}$ Sector (Sec. IV.A) & 204 & $1 / 204$ \\
\hline$N R \varnothing D *$ & Array Locating Element to $30^{\circ}$ Sector (Sec. IV.A) & 85 & $205 / 289$ \\
\hline NP & Element Control Array $0=$ in, $1=$ out & 85 & $290 / 374$ \\
\hline $\mathrm{T}$ & Channel Coolant Temperature, ${ }^{\circ} \mathrm{F}$ & 11,204 & $375 / 2618$ \\
\hline A & Channel Area, in. ${ }^{2}$ & 11,204 & $2619 / 4862$ \\
\hline $\mathrm{W}$ & Channel Flow Rate, lb/hr & 11,204 & $4863 / 7106$ \\
\hline TFC & Fuel Centerline Temperature, ${ }^{\circ} \mathrm{F}$ & 11,85 & $7107 / 8041$ \\
\hline TFS & Fuel Surface Temperature, ${ }^{\circ} \mathrm{F}$ & $11,85,6$ & $8042 / 13651$ \\
\hline TGI & Barrier Surface Temperature, ${ }^{\circ} \mathrm{F}$ & $11,85,6$ & $13652 / 19261$ \\
\hline TCI & Cladding/Barrier Interface Temperature, ${ }^{\circ} \mathrm{F}$ & & $19862 / 24871$ \\
\hline $\mathrm{TC} \varnothing$ & Coolant/Cladding Interface Temperature, ${ }^{\circ} \mathrm{F}$ & $11,85,6$ & $24872 / 30481$ \\
\hline PSEG & Segment Power, kwt/ft & $11,85,6$ & $30482 / 36091$ \\
\hline $\mathrm{B} \emptyset \mathrm{WMFG}$ & $\begin{array}{l}\text { Manufacturing Bow Direction Angle, deg } \\
\quad \text { (input or computed) }\end{array}$ & 85 & $36092 / 36176$ \\
\hline ELBØWM & $\begin{array}{l}\text { Length Cold End to Maximum Manufacturing } \\
\text { Bow, in. (input or computed) }\end{array}$ & 85 & $36177 / 36261$ \\
\hline BWMFML米 & Manufacturing Bow Multipliers (input or computed) (1) & 85 & $36262 / 36346$ \\
\hline SPRING & Element Spring Constant, lb/in. & 121 & $36347 / 36467$ \\
\hline$\varnothing D C L D$ & Cladding OD with Tolerance Effects, in. & 85 & $36468 / 36552$ \\
\hline TCLD & Cladding Thickness with Tolerance Effects, in. & 85 & $36553 / 36637$ \\
\hline RFIN & Fin Radius at Contact Point, in. & 85 & $36638 / 36722$ \\
\hline FMIX & Channel Mixing Rate, \%/in. & 10,204 & $36772 / 38811$ \\
\hline FILM & Channel Film Coefficient, Btu $/ \mathrm{hr}-\mathrm{ft}^{2}-{ }^{\circ} \mathrm{F}$ & 11,204 & $38812 / 41055$ \\
\hline ANGP $*$ & $30^{\circ}$ Sector Element Angle, deg & 10 & $41056 / 41065$ \\
\hline RADP & $30^{\circ}$ Sector Element Radius, in. & 10 & $41066 / 41075$ \\
\hline$A N G C *$ & $30^{\circ}$ Sector Channel Angle, deg & 20 & $41075 / 41095$ \\
\hline RADC & $30^{\circ}$ Sector Channel Radius, in. & 20 & $41096 / 41115$ \\
\hline ARC & $30^{\circ}$ Sector Channel Area, in. ${ }^{2}$ & 20 & $41116 / 41135$ \\
\hline ARF & $30^{\circ}$ Sector Fin Area, in. ${ }^{2}$ & 20 & $41136 / 41155$ \\
\hline PWC & $30^{\circ}$ Sector Channel Perimeter, in. & 20 & $41156 / 41175$ \\
\hline PLOAD & Element Contact Force, lb & 85 & $41176 / 41260$ \\
\hline SMARG & Minimum Element Margin of Safety & 85 & $41261 / 41345$ \\
\hline SEQUIV & Element Equivalent Stress, psi & 85 & $41346 / 41430$ \\
\hline SLOAD & Saved Loads for Convergence Check, lb & 85 & $41431 / 41515$ \\
\hline DEF L4 & Free Deflection at Contact Plane, in. & 85 & $41516 / 41600$ \\
\hline PHI4 & Free Deflection Angle at Contact Plane, deg & 85 & $41601 / 41685$ \\
\hline \multirow[t]{2}{*}{ PHIM } & Mechanical Deflection Angle, deg & 85 & $41686 / 41770$ \\
\hline & Not Used & 70 & $41771 / 41840$ \\
\hline
\end{tabular}

*Denotes Data Built-In () or see text 
TABLE 5

/FRCBAL/ LABELED COMMON DESCRIPTION (8330)

\begin{tabular}{|c|c|c|c|}
\hline Symbol & Data & Dimension & Location \\
\hline $\mathrm{X}$ & Axial Station, in. & 13 & $1-13$ \\
\hline BWMF & Manufacturing Bow, in. & 13,85 & $14-1118$ \\
\hline DFT & Thermal Bow, in. & 13,85 & $1119 / 2223$ \\
\hline PFT & Mechanical Bow, in. & 13,85 & $2224 / 3328$ \\
\hline SIXS & Six $\theta$ Stress, psi & 6,85 & $3329 / 3838$ \\
\hline BEND & Bending Stress, psi & 6,85 & $3839 / 4348$ \\
\hline TOTSTR & Total Stress, psi & 6,85 & $4349 / 4858$ \\
\hline BWDFCN & Contact Plane Manufacturing Bow, in. & 85 & $4859 / 4943$ \\
\hline THDFCN & Contact Plane Thermal Bow, in. & 85 & $4944 / 5028$ \\
\hline THANCN & Contact Plane Thermal Bow Angle, deg & 85 & $5029 / 5113$ \\
\hline PHIR & Contact Plane Resultant Bow, Angle, deg & 85 & $5114 / 5198$ \\
\hline DEFR & Contact Plane Resultant Bow, in. & 85 & $5198 / 5283$ \\
\hline HOOP & Hoop Stress, psi & 6,85 & $5284 / 5793$ \\
\hline AXIAL & Axial Stress, psi & 6,85 & $5794 / 6303$ \\
\hline EQSTR & Equivalent Stress, psi & 6,85 & $6304 / 6813$ \\
\hline $\mathrm{P}$ & Contact Load, lb & 85,6 & $6814 / 7323$ \\
\hline PHIBOW & Bow Angle vs $Z / L$, deg & 11,85 & $7324 / 8258$ \\
\hline $\mathrm{PE}$ & Internal Reflector Load, $1 b$ & 36 & $8258 / 8294$ \\
\hline PHIE & Internal Reflector Bow Angle, deg & 36 & $8295 / 8330$ \\
\hline
\end{tabular}

TABLE 6

/SHRT / LABELED COMMON DESCRIPTION

(3433)

\begin{tabular}{l|l|c|c}
\hline \hline Symbol & \multicolumn{1}{|c|}{ Data } & Dimension & Location \\
\hline QN $\varnothing \mathrm{D}$ & Heat Flux Through Pressure Vessel (Btu/hr) & 10,66 & $1 / 660$ \\
TPVAV & Average Pressure Vessel Temperature, ${ }^{\circ} \mathrm{F}$ & 10,66 & $661 / 1320$ \\
TIRI & Core Side Inner Reflector Temperature, ${ }^{\circ} \mathrm{F}$ & 10,66 & $1321 / 1980$ \\
TIR & Shell Side Inner Reflector Temperature, ${ }^{\circ} \mathrm{F}$ & 10,66 & $1981 / 2640$ \\
TBP & Bypass Coolant Temperature, ${ }^{\circ} \mathrm{F}$ & 11.66 & $2641 / 3366$ \\
WDB & Bypass Flow, lb/hr & 66 & $3367 / 3432$ \\
$\mathrm{~N}$ & Number of Segments in Inner Reflector & 1 & 3433 \\
\hline
\end{tabular}


(382-396) POR - This data is needed for gap conductivity computation. Normally it is obtained from a TEMPRO run. (13) However, a simple symmetric GEOM run can be made to determine temperatures, using a high He loading and back calculating this table from a $\mathrm{ZrH}$ phase diagram. The number of $x-y$ pairs is placed in the first table location, the next two are blank then $x_{1}-y_{1}, x_{2}-y_{2}$, etc.

(12478) SEED - The random number generator seed value is set = $\mathrm{WD} \varnothing \mathrm{T} * \mathrm{TIN} * \mathrm{PN} \varnothing \mathrm{M} * \mathrm{SEED}$. If the first three variables were the same in different runs, the quasi-random numbers would not change, thus this value is needed for control.

\section{B. PROGRAM OPTIONS}

The scope of core thermal analysis must encompass many design features and must be capable of a wide variety of parameter manipulation to provide a powerful tool. This section describes the options built into GEOM by number and symbol:

(26) XMIX - If $>0$, cross flow (mixing) is considered

(27) SHRT - Controls method of core edge heat transfer:

$0=$ none

1 = Pressure vessel temperature fixed

2 = Bypass flow, pressure vessel is adiabatic wall

3 = Radiation to surroundings

(A negative value causes data to be required in /DATOUT/, i. e., EM)

(29) FLAG - This flag skips spacing calculations for consecutive runs where geometry does not vary.

(39) PWFLG - This flag invokes calculation of bypass flow in the core edge if input $>0$. This is used in conjunction with the ring-type reflector described above. Bypass is apportioned strictly by flow area if PWFLG $\leq 0$.

(44) SPCFLG - If greater than 0, the code simply calculates the data of Table 13 (see Section VI for Tables 7 through 30 ). 
(45) DEBUG - If > 0, interim calculations are printed to assist the program user in finding errors in either the code or the data.

(46) ZOLFLG - If $>0, Z / L$ is input, otherwise, 11 equal increments are as sumed.

(47) DATFLG - The program reads as many comment cards as the value input (see Table 8) to identify the particular run.

(48) RIPL - Prior to inclusion of the force balance, GEOM provided punched data cards to an external stress code. This option is still available but no longer used. See Reference 3 for use.

(49) PWRFLG - Normally, the radial heat transfer loop (Figure 14) converges within three iterations. For difficult cases this can be varied by simple input of the iteration limit.

(50) XMLTFL - This flag is used to reset TGM and AM at the end of a run to ensure no carryover to the next run.

(51) CMPMLT - This flag invokes computation of AM and TGM. The use of the force balance automatically sets it for AM.

NOTE: 1 = AM $2=$ TGM $3=$ AM \& TGM for (5) and (51).

(52) BZSET $\}$ - These flags set B $\Phi W Z \Phi L$ and $A S Y Z \Phi L(K, N), K=2,11$ )

(53) ASSET to $X(1, N)$ (if input) for ease in input of like values.

(54) DRREST - This flag resets B $\Phi$ WDIR and ASYDIR to 0 after multiplier calculation to avoid carryover to next run. Value is same as noted for (50) and (51).

(62) ECLD - Input of this value invokes the force balance. Must be 0 if mechanical loop is excluded.

(95) BWLMT - Same restraint on mechanical loop as PWRFLG is to radial heat transfer loop.

(101) VEC - This flag is a five-digit number to control random vector calculations as follows: 


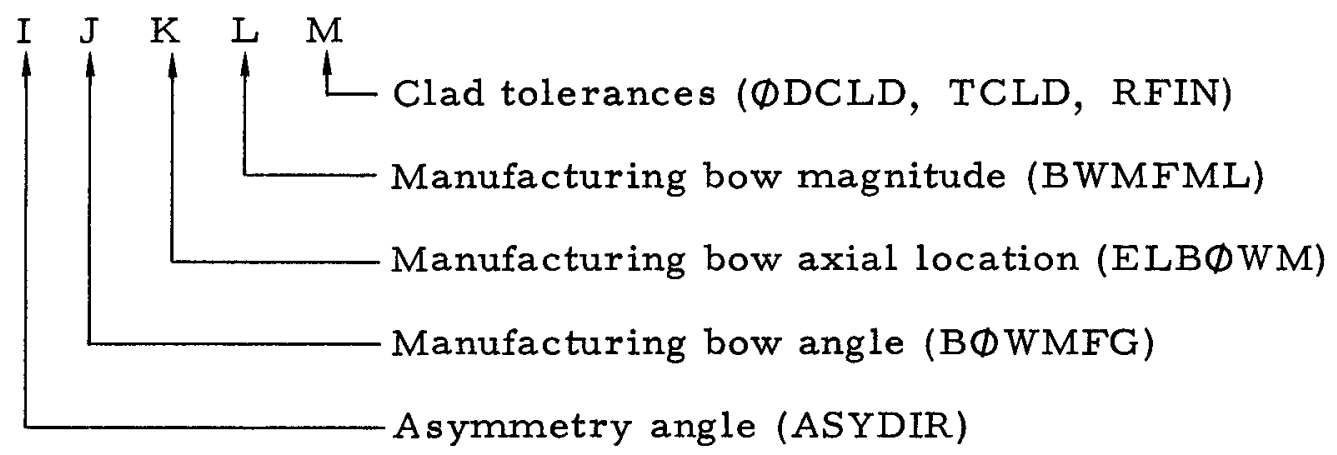

A value of 1 causes calculation, 0 bypasses.

(102) DTOUT - This flag permits reading data into /DATOUT/, primarily $B \Phi W M F G, E L B \Phi W M$ and BWMFML.

(103) BWФPT - This flag permits manipulation of the manufacturing bow angle as follows:

$1=$ Bow angle remains as input or computed.

2 = Bow angle always coincident with thermal bow.

3 = Bow angle always opposing load bow (if load is 0 for a given element, option reverts to 2 ).

$4=$ Bow angle set at thermal bow angle computed for straight elements.

NOTE: Angles referred to are those at contact plane.

(109) SPRFLG - Stress details are always printed for critical element. This flag permits output for all elements.

(12477) SCKFLG - Fin interference check control.

(12485) RNASY ] Fuel slug assymmetry control. Described by

(12486) XMASY ${ }^{-}$sample problem, Section VI.

(12488) $A B C D E-V a l u e$ corresponding to Figure 8 would be 22232. Use only as many digits as there are fuel slugs. Not required for a one-piece fuel rod.

(12489) FNLR - Similar to (45) for aid in program debugging. NLERR prints data in all four labeled common blocks. 
(12490) RVRSE - This flag is used to gauge the relative effects of manufacturing bow and asymmetry on a particular core when applied at the same angle.

(12491) PRTLAM - GEOM has been used to approximate transient conditions. This flag prints 1 for turbulent and 2 for laminar flow for each of the 204 channels. Output occurs at the bottom of Table 13.

(12492) TOLWAY - This flag controls method of applying tolerances to clad. It is a three-digit number IJK where:

$$
\begin{aligned}
\mathrm{I} & =\text { thickness } \\
\mathrm{J} & =\text { inside diameter } \\
\mathrm{K} & =\text { fin height }
\end{aligned}
$$

The value controls calculation as follows:

$$
\begin{aligned}
& 0=\text { random } \pm \\
& 1=\text { plus only } \\
& 2=\text { minus only }
\end{aligned}
$$

These options give the program extreme flexibility and their use singly or in combination make GEOM an extremely powerful analysis tool.

\section{JOB SUBMITTAL}

At the time of preparing this document, the code resided on a disc pack at the Rockwell International Computing Center. The deck setup was as shown in Figure 18. Should the binary decks be used, the two // control cards shown would need to be replaced with JCL as required by the system used.

The data format is:

$$
\text { I12, } 5 \mathrm{~F} 12.8,2 \mathrm{~A} 4
$$

A minus sign in Column 2 denotes the end of the data block input. Note that if no data is read into/DATOUT/ the end of data read should be omitted. The title card is always required and reads in an 18A4 format. The title should be centered in the 72-character space for neat printout (see Section VI-Sample Problem). Comment cards also use an 18A4 format and are required as 


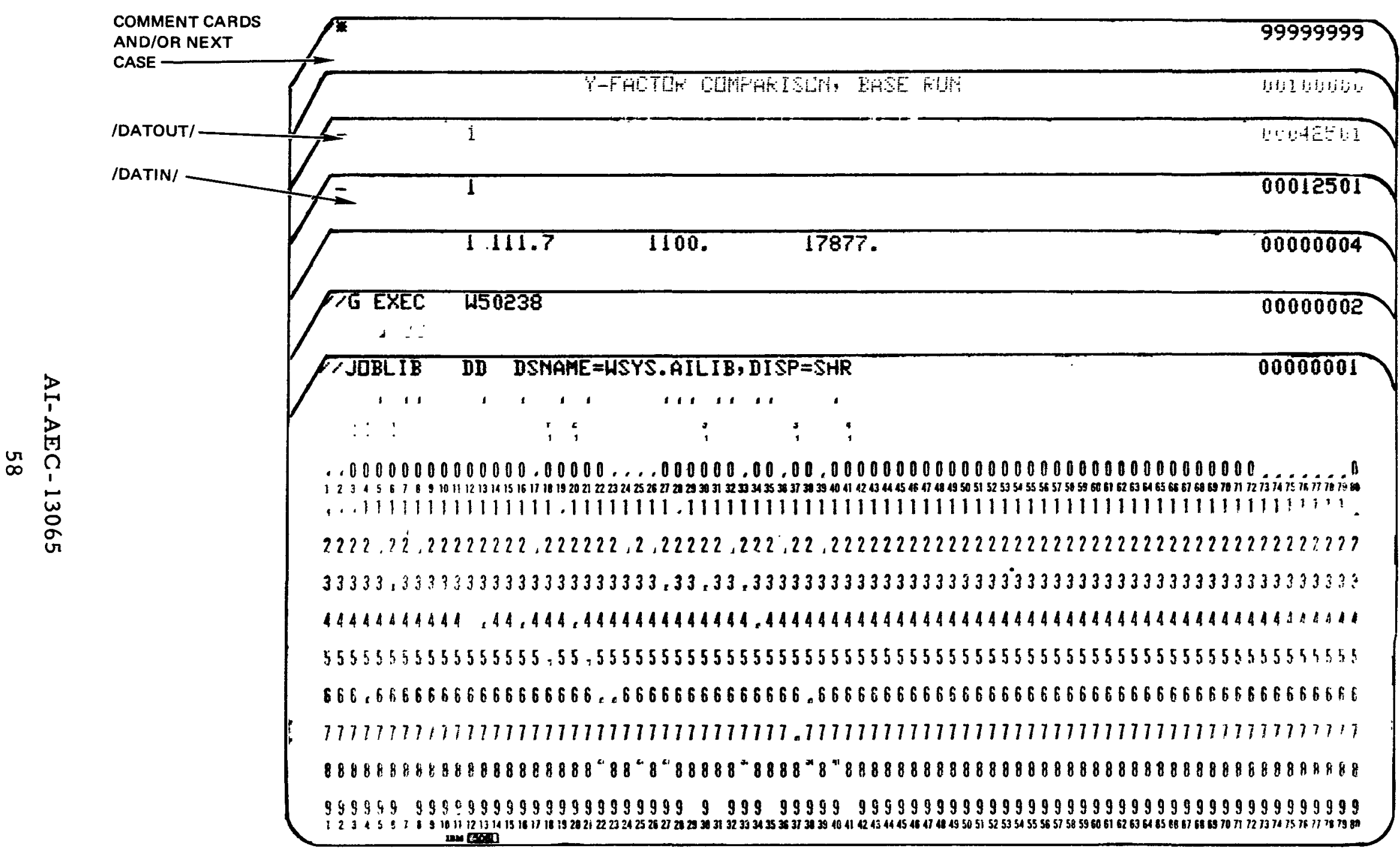

$6531-1130$

Figure 18. Basic Deck Setup 
controlled by DATFLG. Subsequent cases may be run in a single job step by entering only that data which changes. All previous input data remains the same unless changed by the program run calculations.

The program requires $444 \mathrm{~K}$ bytes of storage. A single run, excluding the mechanical loop, requires approximately $2.5 \mathrm{~min}$ of time on the OS $360 / 85 \mathrm{com}$ puter. A three-iteration limit mechanical loop requires approximately 9 min. If the program is loaded from cards, add approximately $1 \mathrm{~min}$ for the link edit step. 
•

\section{BLANK}




\section{SAMPLE PROBLEM}

Tables 7 through 30 show typical output for a typical run. The total output is 210 pages plus the number of pages required to record the input data. For obvious reasons only typical sheets are presented.

This particular run randomized all element variables except that the manufacturing bow was always held to the 6-mil maximum. Mixing was included and the core radiated heat to the external reflector. Each element contained five fuel slugs and their orientation was random but always deflected to $90 \%$ of the nominal gap. The TIR was between 7 and 13 in. from the cold end.

Table 7 shows the typical input data printout - five pieces of data and the first data location per line. Note that the data from 11340 on is the $(11,85)$ PHI array. These cards were punched to the proper format by an external nuclear calculation program, indicating another method of minimizing input effort.

Table 8 shows typical comments for a given run. This sheet is important in completely identifying the variables considered in the run. The numbers in parentheses indicate the number of sheets output for the category shown by the table.

Tables 9 and 10 show the random parameters calculated by DRVECT. Table 11 shows the asymmetry multiplier array. In this particular run, these multipliers are only applied to the angle. For angular multiplication a factor of 10 is applied. Thus, for element one having a base angle of 213 degrees, the five slugs would be oriented at 46, 310,249, 35, and 322 degrees, respectively, from the cold end. Had these multipliers been used on gap as well, for a maximum allowable asymmetry of 6 mils, the slug values would have been $5.2,0.9,0.7,2.1$, and 2.9 mils, respectively.

Table 12 shows the element bow deflection data. These data are shown at stations, given in inches from the cold end, which correspond to the fuel rod nodes. The two bows which form the total free deflection are given, as is the resultant bow and its corresponding angle. Note the angle reversal in elements 3, 4, and 7 showing the effect of hot-end looseness. The angle of manufacturing bow was shown in Table 9 and that for thermal bow is shown in Table 27. Loads and their angles are shown in Table 28. 
Table 13 shows core average and nominal channel hydraulics and geometry and develops ring average data for a life history type program called TEMPRO. (13)

Tables 14 through 18 show the channel temperatures, areas, flows, mixing rates and film coefficients respectively. The channel areas reflect the tolerance effect on clad diameter as well as the element deflections. These effects also cause mixing rates to fluctuate. Note the buildup of mixing rate axially modeling the actual swirl development in an actual core. The film coefficient reflects the mixing rate variation. At the first node there is no mixing because the fins have not started at this point. The fins are ended prior to the last node, however, the program considers them still there since the momentum of the swirl has not yet dissipated.

Table 19 shows the individual element thermal details. Temperatures read inward from the coolant channel with PSEG denoting the segment power output in kwt/ft. Note the asymmetry effects on PSEG corresponding to the angles given above from Table 11. The peak fuel temperature is also shown as TFC. Table 20 shows the summary thermal printout of peak fuel and channel outlet temperatures.

Tables 21 through 24 show the core edge heat transfer. The second sheet, corresponding to Table 21 , summarizes the losses. Typically, radiating to the reflector, these losses are 1 to $2 \%$ of core power for a low power density core. As core power density increases, the percentage usually decreases. As this run precluded a bypass flow, no data printed out. If a bypass is included, the data is output.

Table 25 presents a core bundle cross-sectional area breakdown for rough estimates of weight, volume, etc. Table 26 presents the clad temperature variation discussed in Section III.F. The data starts at $\theta=0$.

Table 27 shows the equivalent cross-element $\Delta T$ which provides the basis for calculating thermal bow. While this data is a rough indicator of forces, larger deflections can occur for elements with lower peak $\Delta T^{\prime}$ s than for higher peak $\Delta \mathrm{T}^{\prime} \mathrm{s}$ since the total deflection is calculated by integrating the $\Delta \mathrm{T}$.

Table 28 shows the results of the force balance and stress details for the element exhibiting the lowest margin of safety. Note that elements 16 and 31 
are opposing thus exhibit the same force. However, the differences in $6 \theta$ temperatures and clad dimensions affecting stresses result in a slightly lower equivalent stress for 31. Table 29 shows the optional stress printout for each element. Table 30 shows the interference check output. This check is made primarily to determine the need for undercutting the fins to avoid secondary contact. 
TABLE 7

TYPICAL INPUT DATA SHEET

(VAR)

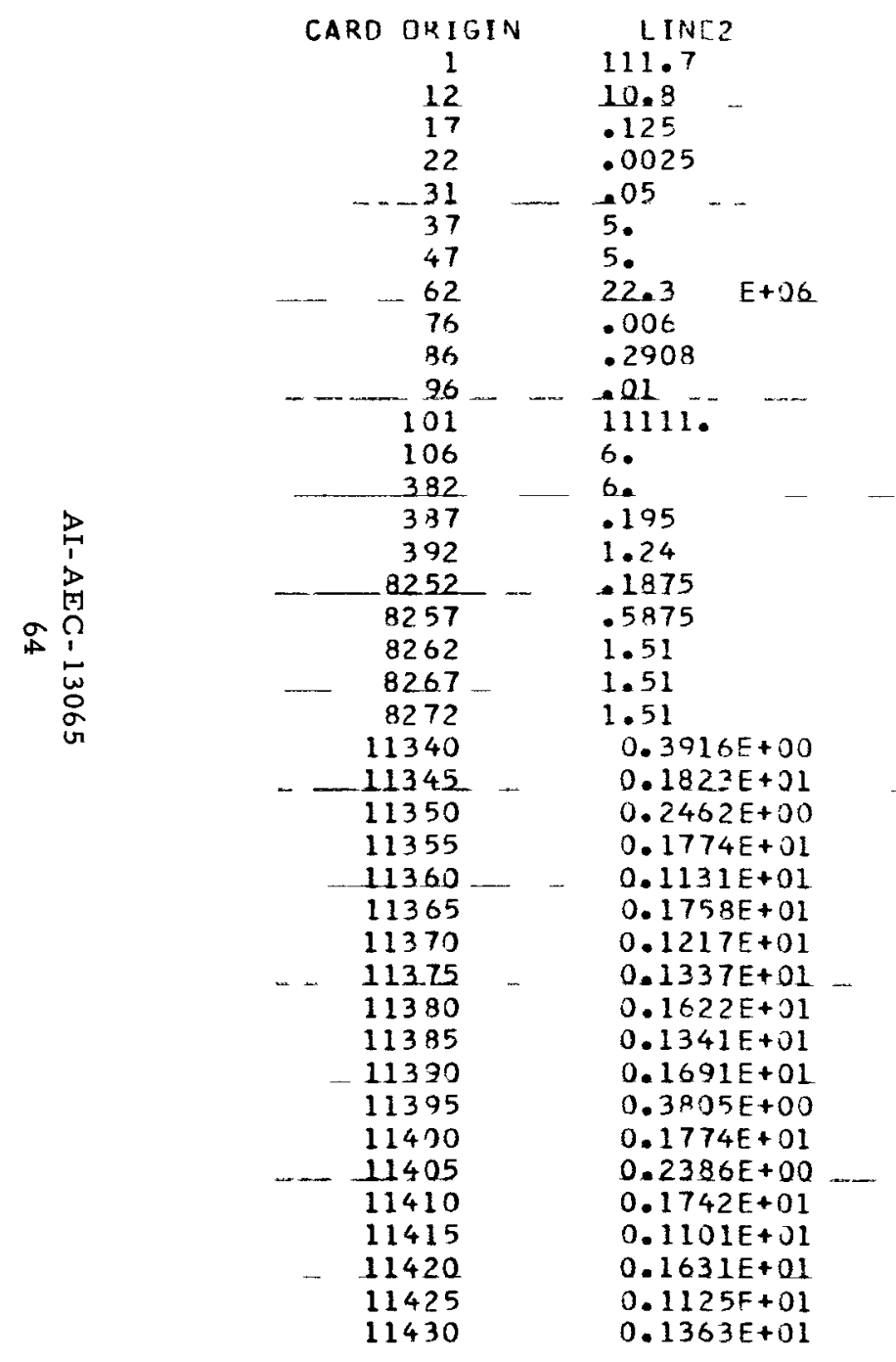

LIVE 3
1100.
10.8
02
.938
.01
9.4


10.583
1.
1.53
.706
.2125
.6250
1.51
1.51
$0.1380 \mathrm{E}+01$
$0.1739 \mathrm{E}+01$
$0.3805 \mathrm{E}+00$
$0.1774 \mathrm{E}+01$
$0.2386 \mathrm{E}+00$
$0.1774 \mathrm{E}+01$
$0.1121 \mathrm{~F}+01$
$0.1719 \mathrm{E}+01$
$0.1188 \mathrm{E}+01$
$0.1421 \mathrm{E}+01$
$0.1632 \mathrm{E}+01$
$0.1341 \mathrm{E}+01$
$0.1691 \mathrm{~F}+01$
$0.3257 \mathrm{E}+00$
$0.1761 \mathrm{E}+01$
$0.2296 \mathrm{E}+00$
$0.1644 \mathrm{E}+01$
$0.1046 \mathrm{E}+01$
$0.1674 \mathrm{E}+01$

LINE
17877.

.01

1. 39333

1.

015 - ....

I.

1.
.355
1.04
$.3875--$
.7875
1.51
1.51

$0.1462 F+01$

$0.1679 E+01$

$0.1341 E+01$

$0.1691 \mathrm{E}+01$

$0.3805 E+00$

$0.1774 E+01$

$0.2386 F+00$

$0.1742 E+01$

$0.1101 E+01$

$0.1758 F+J 1$

$0.1217 E+01$

). $1421 E+01$

$0.1632 E+01$

$0.1253 E+01$

$0.1684 \mathrm{E}+01$

$0.3603 E+50$

$0.1636 E+01$

$0.2184 E+00$

$0.1688 E+01$

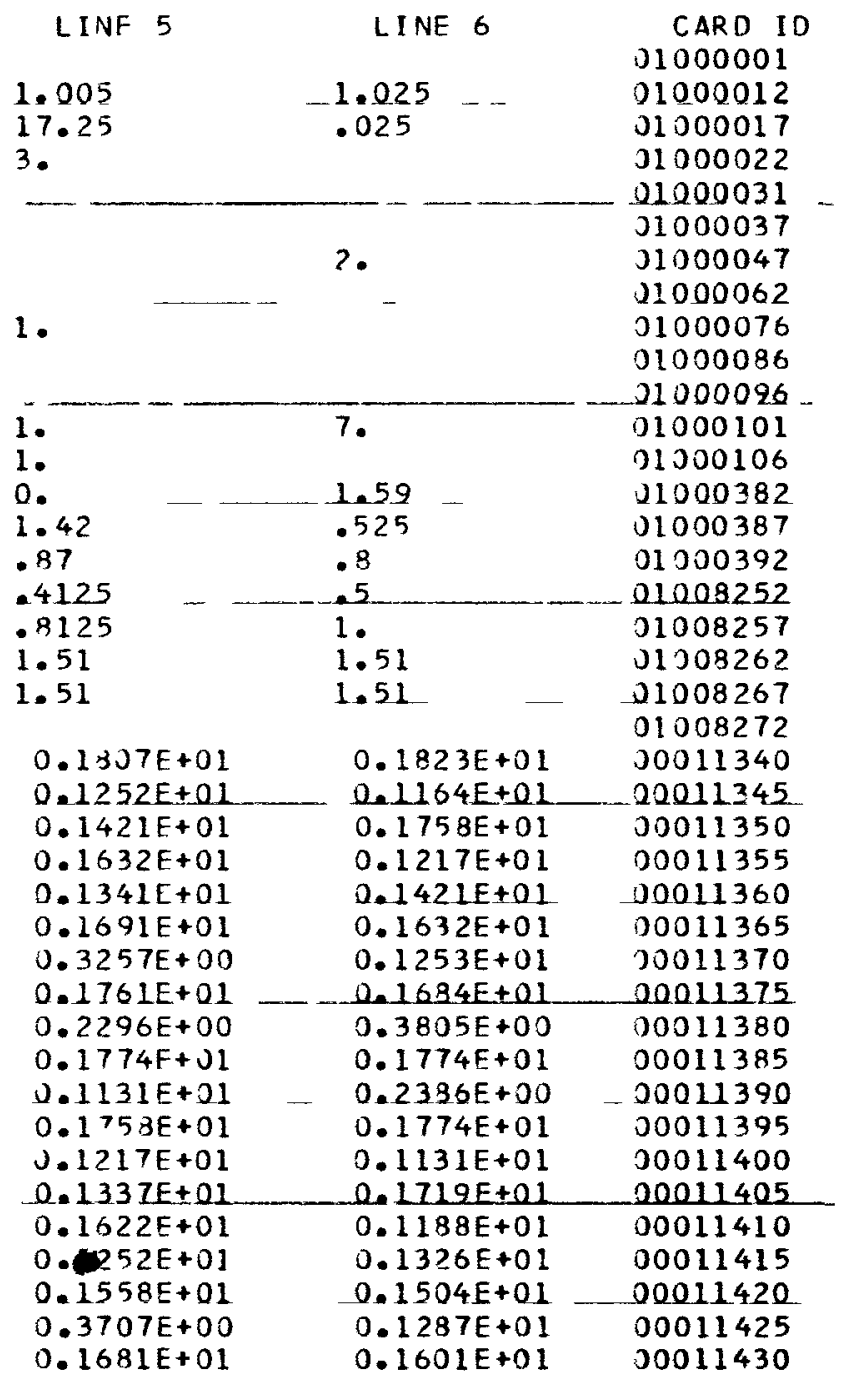


TABLE 8

TYPICAL COMMENTS SHEET

(1)

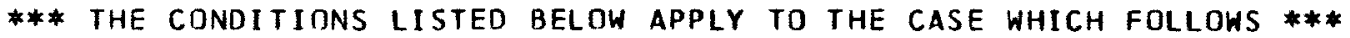
5 KWE RANDOM CORE RUN 1A, $12 / 1 / 72$

(1) DESIGN TO POWER \& FLOW, BOL POWER DISTRIBUTION

(2) ALL TOLERANCES RANDOM, 5 FUEL SLUGS

(3) MANUFACTURING BOW FULL 6 MILS

(4) ASYMMETRY DIRECTION RANDOM, MAGNITUDE MAXIMUM

(5) GEOM MUNFL C.URRENT WITH BIJLLETIN NUMBER 8 
TABLE 9

TYPICAL RANDOM VECTOR SHEET

(1)

5 KWE RANDOM CDRE RUN 1A, 12/1/72

\begin{abstract}
RANDOM ASYMMETRY ANGLES
\end{abstract}

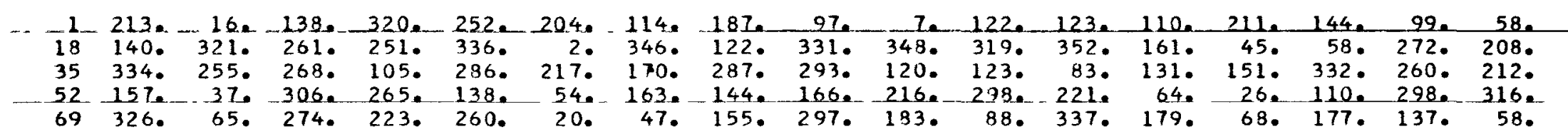

BANDQM MANUFACTURING BOW ANGLES

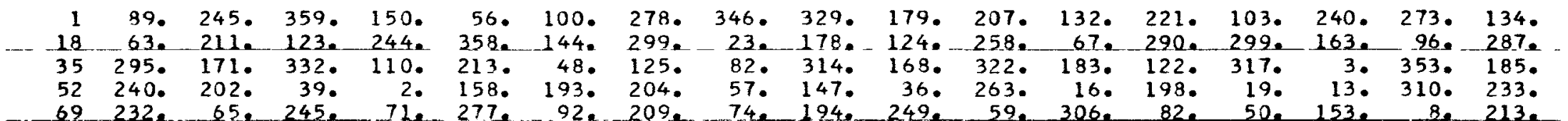

RANDOM MAXIMUM MANUFACTURING BOW LENGTHS

\begin{tabular}{|c|c|c|c|c|c|c|c|c|c|c|c|c|c|c|c|c|c|}
\hline $\begin{array}{r}1 \\
18 \\
35 \\
52 \\
69\end{array}$ & $\begin{array}{r}8.1 \\
11.8 \\
11.7 \\
7.8 \\
8.5\end{array}$ & $\begin{array}{r}7.1 \\
8.4 \\
11.7 \\
7.1 \\
3.1\end{array}$ & $\begin{array}{r}11.4 \\
11.9 \\
12.2 \\
8.8 \\
10.6\end{array}$ & $\begin{array}{r}10.4 \\
7.2 \\
7.4 \\
12.4 \\
8.6\end{array}$ & $\begin{array}{r}12.5 \\
3.3 \\
10.1 \\
9.9 \\
8.3\end{array}$ & $\begin{array}{r}12.4 \\
9.5 \\
8.5 \\
11.6 \\
12.7\end{array}$ & $\begin{array}{r}9.4 \\
12.6 \\
8.4 \\
8.9 \\
9.9\end{array}$ & $\begin{array}{r}8.9 \\
7.3 \\
12.0 \\
10.9 \\
9.4\end{array}$ & $\begin{array}{r}9.9 \\
9.4 \\
10.0 \\
12.9 \\
7.1\end{array}$ & $\begin{array}{l}8.8 \\
8.5 \\
9.9 \\
8.9 \\
9.9\end{array}$ & $\begin{array}{r}7.2 \\
8.0 \\
11.2 \\
8.5 \\
7.9\end{array}$ & $\begin{array}{r}11.5 \\
10.6 \\
11.1 \\
7.8 \\
9.6\end{array}$ & $\begin{array}{r}9.1 \\
9.0 \\
10.9 \\
11.0 \\
12.7\end{array}$ & $\begin{array}{r}7.9 \\
11.4 \\
10.1 \\
12.9 \\
8.4\end{array}$ & $\begin{array}{r}8.6 \\
11.0 \\
8.8 \\
8.9 \\
10.1\end{array}$ & $\begin{array}{r}8.3 \\
12.4 \\
11.4 \\
11.0 \\
9.1\end{array}$ & $\begin{array}{r}10.7 \\
8.2 \\
8.9 \\
12.1 \\
11.0\end{array}$ \\
\hline
\end{tabular}

RANDOM MANUFACTURING BOW MULTIPLIERS

$\ldots .1 .1 .0001 .0001 .0001 .0001 .0001 .0001 .000 .1 .000 \ldots 1.0001 .0001 .0001 .0001 .0001 .0001 .0001 .0001 .000$ 181.0001 .0001 .0001 .0001 .0001 .0001 .0001 .0001 .0001 .0001 .0001 .0001 .0001 .0001 .0001 .0001 .000

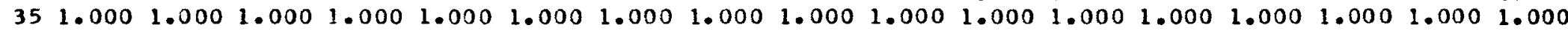
$521.0001 .0001 .0001 .000 \quad 1.0001 .0001 .0001 .0001 .0001 .0001 .0001 .0001 .0001 .0001 .0001 .0001 .000$ 691.0001 .0001 .0001 .0001 .0001 .0001 .0001 .0001 .0001 .0001 .0001 .0001 .0001 .0001 .0001 .0001 .000 
TABLE 10

TYPICAL RANDOM CLAD SHEET

(1)

5 KWE RANDOM CORF RUN 14, $12 / 1 / 72$

RANDOM CLAD DIAMETERS

1
13
25
27
49
61
73
85

1.0052
1.0063
1.0051
1.0035
1.0051
1.0062
1.0022
1.0061

$\begin{array}{lll}1.0054 & 1.0076 & 1.0071 \\ 1.0058 & 1.0049 & 1.0043 \\ 1.0051 & 1.0058 & 1.0032 \\ 1.0051 & 1.0046 & 1.0033 \\ 1.0030 & 1.0036 & 1.0056 \\ 1.0061 & 1.0016 & 1.0067 \\ 1.0050 & 1.0051 & 1.0037\end{array}$

$\begin{array}{lrr}1.0051 & 1.0054 & 1.0021 \\ 1.0054 & 1.0039 & 1.0053 \\ 1.0049 & 1.0056 & 1.0083 \\ 1.0064 & 1.0055 & 1.0046 \\ 1.0051 & 1.0068 & 1.0067 \\ 1.0036 & 1.0054 & 1.0077 \\ 1.0044 & 1.0071 & 1.0260\end{array}$

1.2075 1.0072
1.0045

1.00621 .0058 1.0086 1. 2036 1.0034 1.0030 $1.0048 \quad 1.0053$ 1.0063 1.0061

RANDOM FIN RADII

\subsection{8} $0.5120 \quad 0.5128$ 0.5137 0.5127 0.5127 0.5120 $0.5128 \quad 0.5117$ $0.5127 \quad 0.5119$ 0.51320 .5128 0.5133 0.51150 .5113 0.5118 0.5133

\subsection{9} 0.5123

0.5124

$\begin{array}{llllll}0.5131 & 0.5131 & 0.5117 & 0.5115 & 0.5132 \\ 0.5113 & 0.5119 & 0.5127 & 0.5119 & 0.5132\end{array}$ 1.0070 1.0072 $1.0042 \quad 1.0022$ $-1.0022$ 1. 0070 1.0053 1. 0041 $1.0047 \quad 1.0057 \quad 1.0054 \quad 1.0025 \quad 1.0051$

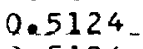

$0.5124-0.5128$.

0.5134

0.5134

0.5120

0.5131

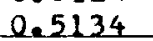

$0.5113-0.5119-0.5127-0.5119-0.5132-0.5130$

$\begin{array}{lllllll}0.5121 & 0.5130 & 0.5132 & 0.5117 & 0.5118 & 0.5139\end{array}$

0.5115

0.5126

0.5129

0.5116

0.5116

0.51310 .5116

0.5133

0.5128

0.5126

0.5125

$0.5126-0.5123$

$0.5130 \quad 0.5115$

0.5123

0.5127

0.5121

RANDOM CLAD THICKNESSES

\begin{tabular}{|c|c|c|c|c|c|c|c|c|c|c|c|}
\hline $\begin{array}{l}.0253 \\
.0253 \\
.0247 \\
.0243 \\
.0252 \\
.0255 \\
.0241\end{array}$ & $\begin{array}{l}0.0251 \\
0.0255 \\
0.0246 \\
0.0248 \\
0.0241 \\
0.0260 \\
0.0245\end{array}$ & $\begin{array}{l}0.0262 \\
0.0250 \\
0.0257 \\
0.0250 \\
0.0239 \\
0.0235 \\
0.0247\end{array}$ & $\begin{array}{l}0.0258 \\
0.0246 \\
0.0237 \\
0.0245 \\
0.0256 \\
0.0262 \\
0.0239\end{array}$ & $\begin{array}{l}0.0248 \\
0.0246 \\
0.0241 \\
0.0260 \\
0.0250 \\
0.0243 \\
0.0249\end{array}$ & $\begin{array}{l}0.0248 \\
0.0240 \\
0.0256 \\
0.0253 \\
0.0259 \\
0.0253 \\
0.0256\end{array}$ & $\begin{array}{r}0.0239 \\
0.0254 \\
0.0263 \\
0.0252 \\
0.0260 \\
0.0261 \\
0.0250\end{array}$ & $\begin{array}{r}0.0259 \\
0.0257 \\
0.0224 \\
0.0243 \\
0.0255 \\
0.0261 \\
0.0246\end{array}$ & $\begin{array}{l}0.0256 \\
0.0265 \\
0.0244 \\
0.0244 \\
0.0263 \\
0.0244 \\
0.0253\end{array}$ & $\begin{array}{l}0.0254 \\
0.0239 \\
0.0243 \\
0.0249 \\
0.0244 \\
0.0252 \\
0.0245\end{array}$ & $\begin{array}{l}0.0251 \\
0.0241 \\
0.0243 \\
0.0238 \\
0.0261 \\
0.0240 \\
0.0245\end{array}$ & $\begin{array}{l}0.0249 \\
0.0260 \\
0.0248 \\
0.0246 \\
0.0245 \\
0.0246 \\
0.0249\end{array}$ \\
\hline
\end{tabular}


TABLE 11

TYPICAL RANDOM ASYMMETRY SHEET

(3)

5 KHE RANDOM CORE RUN 1 A, 12/1/72

ASYMMETRY MULTIPLIER ARRAY - ASYZOL $(11,85)$

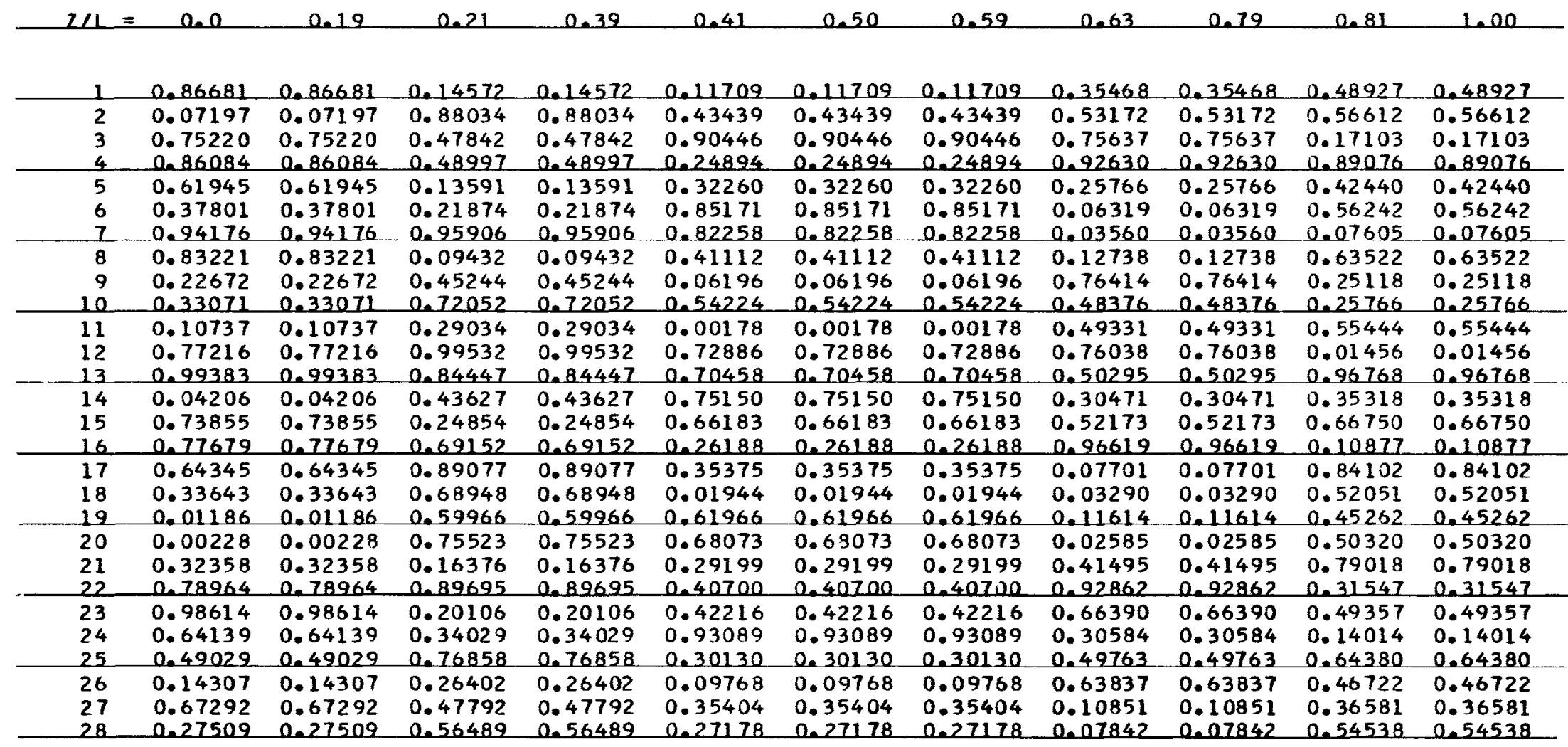


TABLE 12

TYPICAL BOW SUMMARY SHEET

(13)

5 KWE RANDOM CORE RUN 1A, $12 / 1 / 72$

ELEMENT BOW SUMMARY, MILS

\begin{tabular}{|c|c|c|c|c|c|c|c|c|c|c|c|c|}
\hline \multicolumn{2}{|c|}{ ELEM } & $\frac{1.00}{1.162}$ & $\begin{array}{r}4.00 \\
\begin{array}{r}4219 \\
1.486\end{array}\end{array}$ & \multirow{2}{*}{$\begin{array}{r}4.40 \\
4.538 \\
1.625\end{array}$} & \multirow{2}{*}{$\begin{array}{r}7.20 \\
5.916 \\
2.363\end{array}$} & \multirow{2}{*}{$\begin{array}{r}7.60 \\
5.976 \\
2.430\end{array}$} & $\begin{array}{r}9.00 \\
5.922 \\
2.586\end{array}$ & \multirow{2}{*}{$\begin{array}{l}10.40 \\
5.526 \\
2.628\end{array}$} & \multirow{2}{*}{$\begin{array}{c}11.00 \\
5.258 \\
2.609\end{array}$} & \multirow{2}{*}{$\begin{array}{l}13.60 \\
3.504 \\
2.084\end{array}$} & $\frac{14.00}{3.164}$ & \multirow{2}{*}{$\begin{array}{r}17.00 \\
0.256 \\
0.192 \\
0.384 \\
64 .\end{array}$} \\
\hline 1 & $\begin{array}{l}\text { MFG } \\
\text { THR } \\
\text { RES } \\
\text { ANG }\end{array}$ & $\begin{array}{r}1.162 \\
0.387 \\
1.374 \\
75 .\end{array}$ & $\begin{array}{c}4.219 \\
1.486 \\
4.910 \\
73 .\end{array}$ & & & & $\begin{array}{r}5.922 \\
2.586 \\
6.967 \\
68 .\end{array}$ & & & & $\begin{array}{c}3.164 \\
1.931 \\
4.305 \\
66 .\end{array}$ & \\
\hline 2 & $\begin{array}{l}\text { MFG } \\
\text { THR } \\
\text { RES } \\
\text { ANG }\end{array}$ & $\begin{array}{r}1.314 \\
0.169 \\
1.058 \\
264\end{array}$ & $\begin{array}{r}4.636 \\
0.729 \\
3.632 \\
265\end{array}$ & $\begin{array}{r}4.954 \\
0.808 \\
3.852 \\
266\end{array}$ & $\begin{array}{r}5.999 \\
1.008 \\
4.247 \\
279 .\end{array}$ & $\begin{array}{r}5.983 \\
0.981 \\
4.157 \\
282\end{array}$ & $\begin{array}{r}5.746 \\
0.840 \\
3.943 \\
298\end{array}$ & $\begin{array}{l}5.239 \\
0.701 \\
3.972 \\
318 .\end{array}$ & $\begin{array}{r}4.945 \\
0.657 \\
4.113 \\
327 .\end{array}$ & $\begin{array}{r}3.216 \\
0.482 \\
5.703 \\
359 .\end{array}$ & $\begin{array}{r}2.896 \\
0.452 \\
6.082 \\
3 .\end{array}$ & $\begin{array}{c}0.233 \\
0.050 \\
9.658 \\
22\end{array}$ \\
\hline 3 & $\begin{array}{l}\text { MFG } \\
\text { THR } \\
\text { RES } \\
\text { ANG }\end{array}$ & $\begin{array}{c}0.826 \\
0.858 \\
0.969 \\
342 .\end{array}$ & $\begin{array}{r}3.147 \\
3.233 \\
3.467 \\
339 .\end{array}$ & $\begin{array}{c}3.424 \\
3.522 \\
3.726 \\
338 .\end{array}$ & $\begin{array}{c}5.029 \\
4.985 \\
4.670 \\
333 .\end{array}$ & $\begin{array}{r}5.202 \\
5.109 \\
4.664 \\
332 .\end{array}$ & $\begin{array}{c}5.679 \\
5.362 \\
4.383 \\
330 .\end{array}$ & $\begin{array}{r}5.945 \\
5.332 \\
3.746 \\
330 .\end{array}$ & $\begin{array}{c}5.992 \\
5.224 \\
3.352 \\
330 .\end{array}$ & $\begin{array}{r}4.972 \\
3.931 \\
0.137 \\
167 .\end{array}$ & $\begin{array}{c}4.584 \\
3.609 \\
0.980 \\
156 .\end{array}$ & $\begin{array}{c}0.401 \\
0.337 \\
9.209 \\
155 .\end{array}$ \\
\hline 4 & $\begin{array}{l}\text { MFG } \\
\text { THR } \\
\text { RES } \\
\text { ANG }\end{array}$ & $\begin{array}{r}0.903 \\
0.633 \\
0.856 \\
139 .\end{array}$ & $\begin{array}{r}3.411 \\
2.758 \\
3.489 \\
138 .\end{array}$ & $\begin{array}{c}3.703 \\
3.073 \\
3.824 \\
138 .\end{array}$ & $\begin{array}{c}5.315 \\
5.014 \\
5.564 \\
137 .\end{array}$ & $\begin{array}{c}5.473 \\
5.235 \\
5.690 \\
137 .\end{array}$ & $\begin{array}{c}5.868 \\
5.761 \\
5.758 \\
138 .\end{array}$ & $\begin{array}{c}6.000 \\
5.873 \\
5.270 \\
141 .\end{array}$ & $\begin{array}{c}5.942 \\
5.788 \\
4.875 \\
144 .\end{array}$ & $\begin{array}{r}4.452 \\
4.399 \\
1.646 \\
199 .\end{array}$ & $\begin{array}{r}4.065 \\
4.036 \\
1.590 \\
232 .\end{array}$ & $\begin{array}{r}0.343 \\
0.375 \\
9.186 \\
299 .\end{array}$ \\
\hline 5 & $\begin{array}{l}\text { MFG } \\
\text { THR } \\
\text { RES }\end{array}$ & $\begin{array}{r}0.753 \\
0.784 \\
1.524 \\
\end{array}$ & $\begin{array}{r}2.895 \\
3.169 \\
6.045 \\
\end{array}$ & $\begin{array}{r}3.155 \\
3.494 \\
6.629 \\
\end{array}$ & $\begin{array}{r}4.723 \\
5.403 \\
10.116 \\
\end{array}$ & $\begin{array}{r}4.903 \\
5.608 \\
10.501 \\
\end{array}$ & $\begin{array}{r}5.433 \\
6.086 \\
1.513 \\
\end{array}$ & $\begin{array}{r}5.795 \\
6.159 \\
11.954 \\
\end{array}$ & $\begin{array}{r}5.896 \\
6.058 \\
11.954 \\
\end{array}$ & $\begin{array}{r}5.597 \\
4.634 \\
10.221 \\
\end{array}$ & $\begin{array}{l}5.264 \\
4.268 \\
9.519\end{array}$ & $\begin{array}{l}0.494 \\
0.408 \\
0.898 \\
\end{array}$ \\
\hline & ANG & 64 & 61 & 61 & 59. & 59. & 58 & 57. & 56 & 54 & 53 & 51 \\
\hline 6 & $\begin{array}{l}\text { MFG } \\
\text { THR } \\
\text { RES } \\
\text { ANG }\end{array}$ & $\begin{array}{r}0.760 \\
0.701 \\
1.155 \\
134 .\end{array}$ & $\begin{array}{r}2.920 \\
2.639 \\
4.396 \\
137 .\end{array}$ & $\begin{array}{r}3.182 \\
2.874 \\
4.784 \\
138 .\end{array}$ & $\begin{array}{r}4.754 \\
3.993 \\
6.855 \\
143 .\end{array}$ & $\begin{array}{r}4.934 \\
4.071 \\
7.052 \\
145 .\end{array}$ & $\begin{array}{r}5.460 \\
4.210 \\
7.537 \\
149 .\end{array}$ & $\begin{array}{r}5.814 \\
4.157 \\
7.795 \\
154 .\end{array}$ & $\begin{array}{r}5.910 \\
4.071 \\
7.850 \\
158 .\end{array}$ & $\begin{array}{c}5.532 \\
3.022 \\
7.369 \\
177 .\end{array}$ & $\begin{array}{c}5.189 \\
2.759 \\
7.208 \\
182 .\end{array}$ & $\begin{array}{r}0.482 \\
0.249 \\
9.500 \\
237 .\end{array}$ \\
\hline 7 & $\begin{array}{l}\text { MFG } \\
\text { THR } \\
\text { RES } \\
\text { ANG }\end{array}$ & $\begin{array}{c}0.997 \\
0.353 \\
0.822 \\
288 .\end{array}$ & $\begin{array}{r}3.716 \\
1.486 \\
3.005 \\
286\end{array}$ & $\begin{array}{c}4.023 \\
1.648 \\
3.230 \\
286\end{array}$ & $\begin{array}{c}5.597 \\
2.798 \\
4.172 \\
284 .\end{array}$ & $\begin{array}{r}5.729 \\
2.960 \\
4.191 \\
284 .\end{array}$ & $\begin{array}{c}5.986 \\
3.366 \\
3.899 \\
284 .\end{array}$ & $\begin{array}{r}5.882 \\
3.459 \\
2.992 \\
290 .\end{array}$ & $\begin{array}{c}5.697 \\
3.394 \\
2.453 \\
297 .\end{array}$ & $\begin{array}{r}4.006 \\
2.584 \\
2.529 \\
42 .\end{array}$ & $\begin{array}{r}3.635 \\
2.385 \\
3.180 \\
50 .\end{array}$ & $\begin{array}{c}0.300 \\
0.234 \\
9.426 \\
64 .\end{array}$ \\
\hline
\end{tabular}


TABLE 13

TYPICAL CORE AVERAGE SHEET

(1)

5 KWE RANDOM CORE RUN 1A, 12/1/72

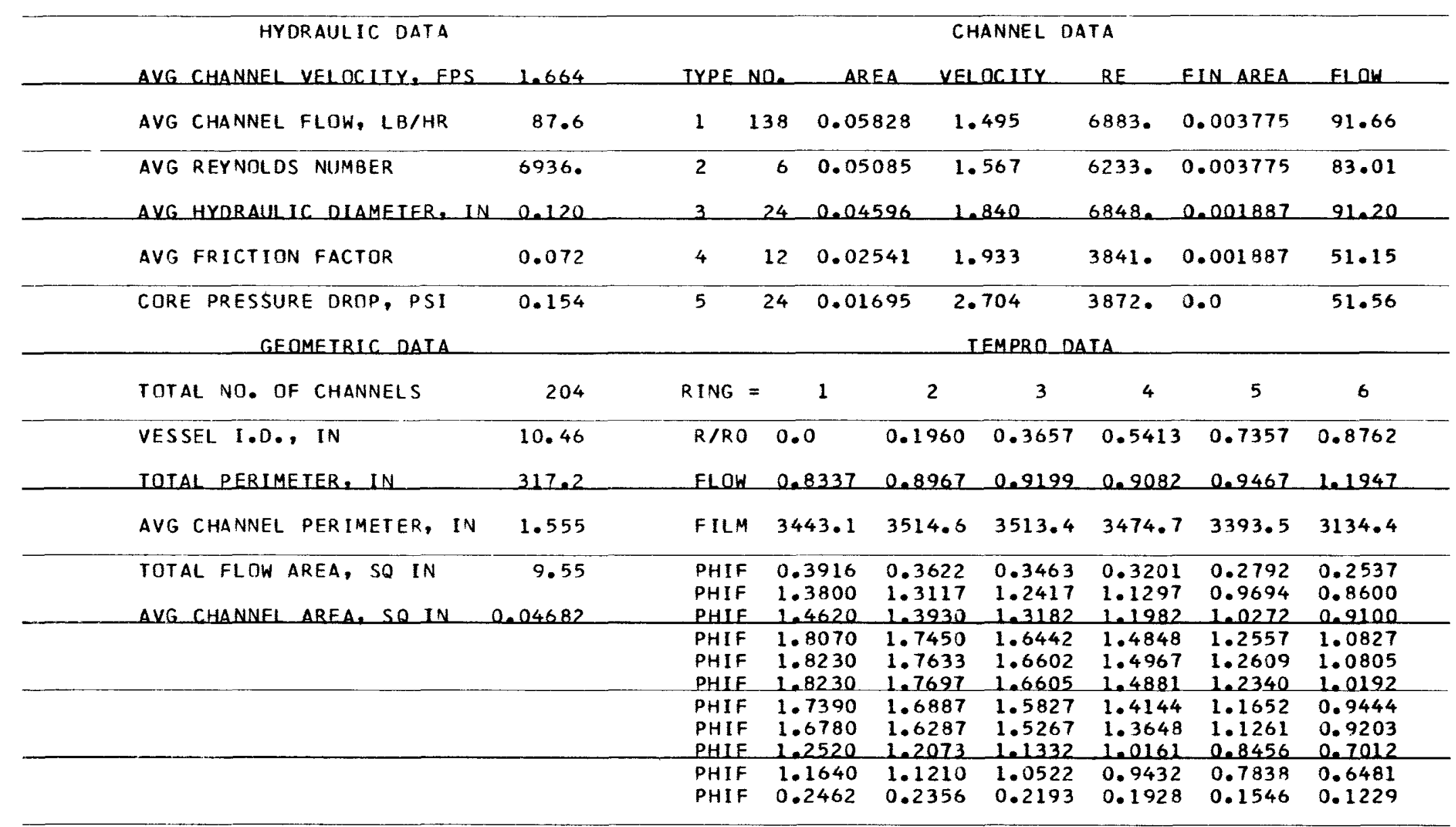


TABLE 14

TYPICAL COOLANT TEMPERATURE SHEET

(6)

5 KHE RANDOM CORE RUN 1A, 12/1/72

COOLANT BULK TEMPERATURE, DEG $F$

\begin{tabular}{|c|c|c|c|c|c|c|c|c|c|c|c|}
\hline$Z / L=$ & 0.0 & 0.19 & 0.21 & 0.39 & 0.41 & 0.50 & 0.59 & 0.63 & 0.79 & 0.81 & 1.00 \\
\hline $\begin{array}{l}1 \\
2 \\
3 \\
4\end{array}$ & $\begin{array}{l}1100.0 \\
1100.0 \\
1100.0 \\
1100.0\end{array}$ & $\begin{array}{l}1120.5 \\
1117.5 \\
1118.8 \\
1115.9\end{array}$ & $\begin{array}{l}1125.2 \\
1121.5 \\
1122.4 \\
1120.3\end{array}$ & $\begin{array}{l}1160 \cdot 7 \\
1154 \cdot 2 \\
1146 \cdot 3 \\
1158.4\end{array}$ & $\begin{array}{l}1165.2 \\
1159.2 \\
1151.2 \\
1163.7\end{array}$ & $\begin{array}{l}1177.1 \\
1176.3 \\
1171.0 \\
1181.2\end{array}$ & $\begin{array}{l}1189.7 \\
1192.8 \\
1188.9 \\
1198.8\end{array}$ & $\begin{array}{l}1197.4 \\
1199.6 \\
1194.0 \\
1205.8\end{array}$ & $\begin{array}{l}1229.2 \\
1224.3 \\
1207.7 \\
1228.1\end{array}$ & $\begin{array}{l}1231.6 \\
1227 \cdot 1 \\
1210.5 \\
1230.6\end{array}$ & $\begin{array}{l}1238.2 \\
1237.1 \\
1226.5 \\
1239.6\end{array}$ \\
\hline $\begin{array}{l}5 \\
6 \\
7\end{array}$ & $\begin{array}{l}1100.0 \\
1100.0 \\
1100.0\end{array}$ & $\begin{array}{l}1117.8 \\
1118.0 \\
1117.4\end{array}$ & $\begin{array}{l}1122.3 \\
1121.8 \\
1121.4\end{array}$ & $\begin{array}{l}1160.5 \\
1152.4 \\
1152.7\end{array}$ & $\begin{array}{l}1166.1 \\
1157.8 \\
1156.8\end{array}$ & $\begin{array}{l}1183.8 \\
1176.2 \\
1169.4\end{array}$ & $\begin{array}{l}1200.7 \\
1193.0 \\
1183.2\end{array}$ & $\begin{array}{l}1207.3 \\
1200.3 \\
1190.0\end{array}$ & $\begin{array}{l}1228.3 \\
1228.5 \\
1218.2\end{array}$ & $\begin{array}{l}1230.7 \\
1231.7 \\
1221.7\end{array}$ & $\begin{array}{l}1240.1 \\
1242.7 \\
1235.4\end{array}$ \\
\hline $\begin{array}{r}8 \\
9 \\
10\end{array}$ & $\begin{array}{l}1100.0 \\
1100.0 \\
1100.0\end{array}$ & $\begin{array}{l}1117.7 \\
1112.8 \\
1113.6\end{array}$ & $\begin{array}{l}1120.3 \\
1115.7 \\
1117.7\end{array}$ & $\begin{array}{l}1139.9 \\
1142.2 \\
1155.8\end{array}$ & $\begin{array}{l}1143.6 \\
1147.1 \\
1161.8\end{array}$ & $\begin{array}{l}1158.5 \\
1166.6 \\
1183.1\end{array}$ & $\begin{array}{l}1174.4 \\
1185.4 \\
1202.4\end{array}$ & $\begin{array}{l}1180.9 \\
1191.5 \\
1208.9\end{array}$ & $\begin{array}{l}1204.4 \\
1210.3 \\
1229.1\end{array}$ & $\begin{array}{l}1207.9 \\
1213.4 \\
1231.8\end{array}$ & $\begin{array}{l}1226.2 \\
1228.8 \\
1241.4\end{array}$ \\
\hline $\begin{array}{l}11 \\
12 \\
13\end{array}$ & $\begin{array}{l}1100.0 \\
1100.0 \\
1100.0\end{array}$ & $\begin{array}{l}1112.9 \\
1116.7 \\
1121.9\end{array}$ & $\begin{array}{l}1116.6 \\
1119.5 \\
1124.0\end{array}$ & $\begin{array}{l}1150.8 \\
1142.4 \\
1141.3\end{array}$ & $\begin{array}{l}1155.8 \\
1146.8 \\
1145.2\end{array}$ & $\begin{array}{l}1172.3 \\
1163.4 \\
1162.1\end{array}$ & $\begin{array}{l}1189.5 \\
1179.7 \\
1178.3\end{array}$ & $\begin{array}{l}1197.2 \\
1186.2 \\
1183.6\end{array}$ & $\begin{array}{l}1224.7 \\
1211.0 \\
1200.9\end{array}$ & $\begin{array}{l}1227.6 \\
1214.8 \\
1204.3\end{array}$ & $\begin{array}{l}1237.3 \\
1232.4 \\
1224.2\end{array}$ \\
\hline $\begin{array}{l}14 \\
15\end{array}$ & $\begin{array}{l}1100.0 \\
1100.0\end{array}$ & $\begin{array}{l}1118.9 \\
1113.8\end{array}$ & $\begin{array}{l}1121.7 \\
1116.5\end{array}$ & $\begin{array}{l}1141.0 \\
1139.6\end{array}$ & $\begin{array}{l}1144.8 \\
1143.4\end{array}$ & $\begin{array}{l}1159.4 \\
1157.0\end{array}$ & $\begin{array}{l}1173.1 \\
1170.9\end{array}$ & $\begin{array}{l}1178.3 \\
1177.5\end{array}$ & $\begin{array}{l}1198.8 \\
1206.0\end{array}$ & $\begin{array}{l}1202.5 \\
1209.8\end{array}$ & $\begin{array}{l}1222.6 \\
1227.7\end{array}$ \\
\hline 16 & 1100.0 & 1113.2 & 1116.8 & 1151.7 & 1156.6 & 1171.8 & 1187.9 & 1195.8 & 1226.4 & 1229.4 & 1240.2 \\
\hline $\begin{array}{l}17 \\
18 \\
19\end{array}$ & $\begin{array}{l}1100.0 \\
1100.0 \\
1100.0\end{array}$ & $\begin{array}{l}1115.8 \\
1116.4 \\
1117.8\end{array}$ & $\begin{array}{l}1119.1 \\
1119.6 \\
1122.2\end{array}$ & $\begin{array}{l}1146.4 \\
1145.8 \\
1157.2\end{array}$ & $\begin{array}{l}1151.0 \\
1150.9 \\
1162.5\end{array}$ & $\begin{array}{l}1167.5 \\
1171.0 \\
1179.4\end{array}$ & $\begin{array}{l}1183.6 \\
1189.1 \\
1195.1\end{array}$ & $\begin{array}{l}1190.6 \\
1194.4 \\
1200.2\end{array}$ & $\begin{array}{l}1217.6 \\
1211.6 \\
1216.4\end{array}$ & $\begin{array}{l}1220.9 \\
1215.2 \\
1219.2\end{array}$ & $\begin{array}{l}1233.5 \\
1233.1 \\
1232.8\end{array}$ \\
\hline $\begin{array}{l}20 \\
21 \\
22\end{array}$ & $\begin{array}{l}1100.0 \\
1100.0 \\
1100.0\end{array}$ & $\begin{array}{l}1117.9 \\
1118.0 \\
1116.8\end{array}$ & $\begin{array}{l}1121.9 \\
1121.5 \\
1120.2\end{array}$ & $\begin{array}{l}1155.4 \\
1149.3 \\
1148.2\end{array}$ & $\begin{array}{l}1159.1 \\
1153.3 \\
1153.3\end{array}$ & $\begin{array}{r}1168.9 \\
1165.9 \\
1172.4\end{array}$ & $\begin{array}{l}1179.6 \\
1179.5 \\
1190.5\end{array}$ & $\begin{array}{l}1185.3 \\
1186.3 \\
1197.5\end{array}$ & $\begin{array}{l}1211.4 \\
1214.2 \\
1223.0\end{array}$ & $\begin{array}{l}1214.5 \\
1217.3 \\
1226.6\end{array}$ & $\begin{array}{l}1227.8 \\
1230.1 \\
1241.8\end{array}$ \\
\hline $\begin{array}{l}23 \\
24 \\
25\end{array}$ & $\begin{array}{l}1100.0 \\
1100.0 \\
1100.0\end{array}$ & $\begin{array}{l}1116.5 \\
1115.6 \\
1115.5\end{array}$ & $\begin{array}{l}1120.1 \\
1119.5 \\
1119.5\end{array}$ & $\begin{array}{l}1148.3 \\
1152.9 \\
1154.3\end{array}$ & $\begin{array}{l}1153.1 \\
1157.8 \\
1159.5\end{array}$ & $\begin{array}{l}1170.3 \\
1174.3 \\
1176.6\end{array}$ & $\begin{array}{l}1136.6 \\
1190.6 \\
1193.2\end{array}$ & $\begin{array}{l}1193.2 \\
1198.7 \\
1200.6\end{array}$ & $\begin{array}{l}1216.9 \\
1229.6 \\
1227.5\end{array}$ & $\begin{array}{l}1219.5 \\
1232.2 \\
1229.8\end{array}$ & $\begin{array}{l}1229.3 \\
1237.9 \\
1234.6\end{array}$ \\
\hline $\begin{array}{l}26 \\
27 \\
28 \\
\end{array}$ & $\begin{array}{l}1100.0 \\
1100.0 \\
1100.0\end{array}$ & $\begin{array}{l}1112.6 \\
1116.9 \\
1117.0\end{array}$ & $\begin{array}{l}1116.1 \\
1120.3 \\
1120.8\end{array}$ & $\begin{array}{l}1146.2 \\
1146.2 \\
1149.5\end{array}$ & $\begin{array}{l}1151.1 \\
1150.8 \\
1153.9\end{array}$ & $\begin{array}{r}1168.5 \\
1168.2 \\
1169.3\end{array}$ & $\begin{array}{l}1184.1 \\
1194.3 \\
1184.5\end{array}$ & $\begin{array}{l}1199.4 \\
1190.8 \\
1191.1\end{array}$ & $\begin{array}{l}1205.7 \\
1212.7 \\
1214.9\end{array}$ & $\begin{array}{l}1208.0 \\
1215.1 \\
1217.3\end{array}$ & $\begin{array}{r}1218.2 \\
1224.9 \\
1225.0\end{array}$ \\
\hline $\begin{array}{l}29 \\
30 \\
31\end{array}$ & $\begin{array}{l}1100.0 \\
1100.0 \\
1100.0\end{array}$ & $\begin{array}{l}11115.1 \\
11115.3 \\
11115.1\end{array}$ & $\begin{array}{l}1118.4 \\
1118.3 \\
1118.2\end{array}$ & $\begin{array}{l}1144.4 \\
1141.9 \\
1140.8\end{array}$ & $\begin{array}{l}1149.7 \\
1146.6 \\
1146.1\end{array}$ & $\begin{array}{l}1163.5 \\
1164.7 \\
1167.3\end{array}$ & $\begin{array}{l}1177.6 \\
1181.2 \\
1186.3\end{array}$ & $\begin{array}{l}1183.3 \\
1187.5 \\
1193.0\end{array}$ & $\begin{array}{l}1203.5 \\
1208.6 \\
1214.2\end{array}$ & $\begin{array}{l}1205.8 \\
1210.6 \\
1216.7\end{array}$ & $\begin{array}{r}1214.4 \\
1217.3 \\
1224.7\end{array}$ \\
\hline $\begin{array}{l}32 \\
33 \\
34\end{array}$ & $\begin{array}{l}1100.0 \\
1100.0 \\
1100.0\end{array}$ & $\begin{array}{l}1114.3 \\
1115.6 \\
1115.1\end{array}$ & $\begin{array}{l}1117.9 \\
1119.2 \\
1118.1\end{array}$ & $\begin{array}{l}1147.6 \\
1147.4 \\
1140.8\end{array}$ & $\begin{array}{l}1152.6 \\
1151.6 \\
1145.9\end{array}$ & $\begin{array}{l}1170.5 \\
1166.4 \\
1166.6\end{array}$ & $\begin{array}{l}1186.9 \\
1181.3 \\
1184.1\end{array}$ & $\begin{array}{l}1193.5 \\
1187.3 \\
1190.8 \\
\end{array}$ & $\begin{array}{r}1216.7 \\
1208.7 \\
1215.8\end{array}$ & $\begin{array}{l}1218.8 \\
1210.7 \\
1218.0 \\
\end{array}$ & $\begin{array}{l}1223.9 \\
1215.2 \\
1222.9\end{array}$ \\
\hline
\end{tabular}


TABLE 15

TYPICAL CHANNEL AREA SHEET

(6)

5 KWE RANDOM CORE RUN 1A, 12/1/72

CHANNEL AREA, SQ. IN.

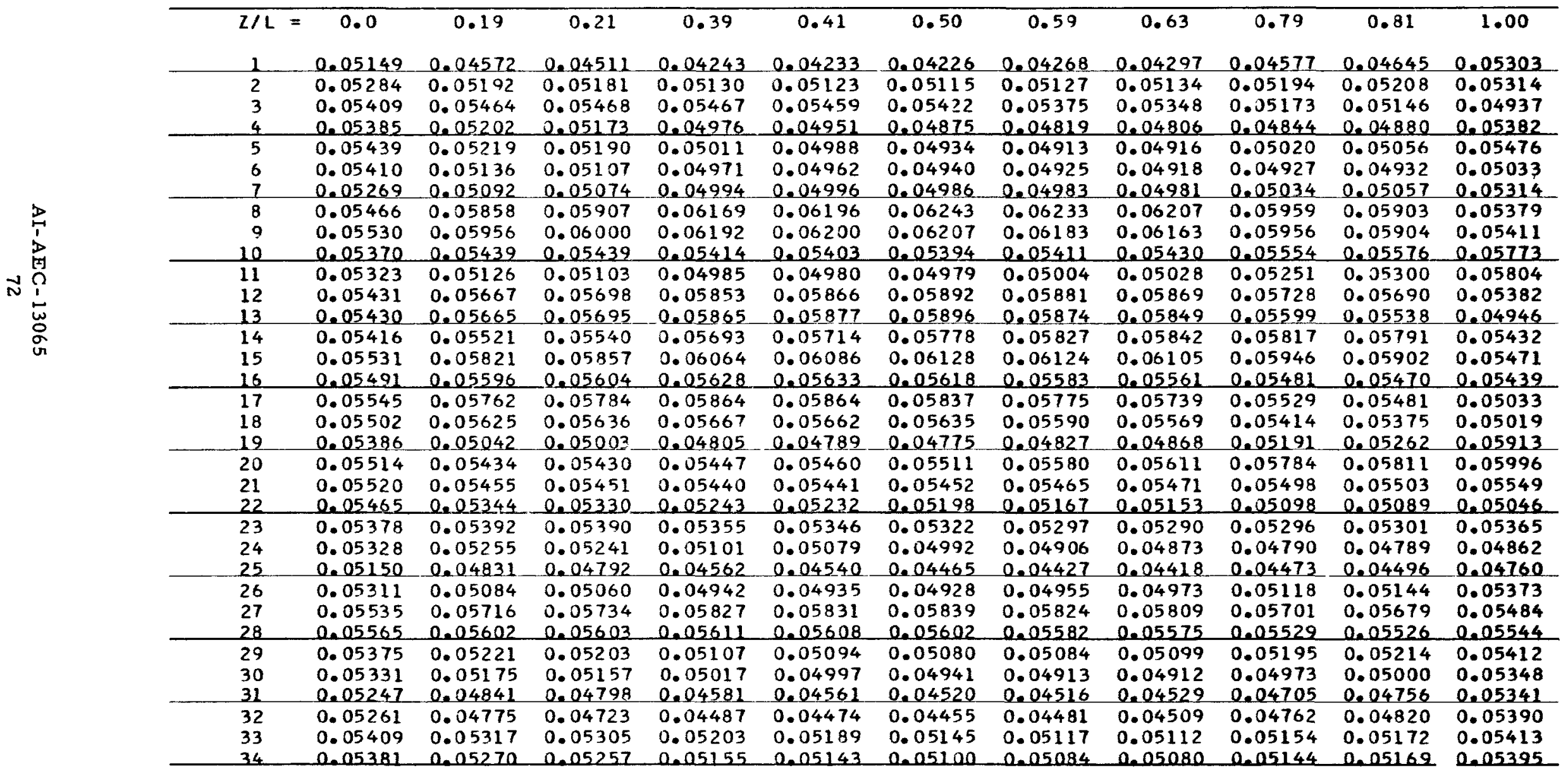


TABLE 16

TYPICAL COOLANT FLOW SHEET

(6)

5 KINE RANDOM CORE RUN 1 A, $12 / 1 / 72$

CODLANT FLOW, LB/HR

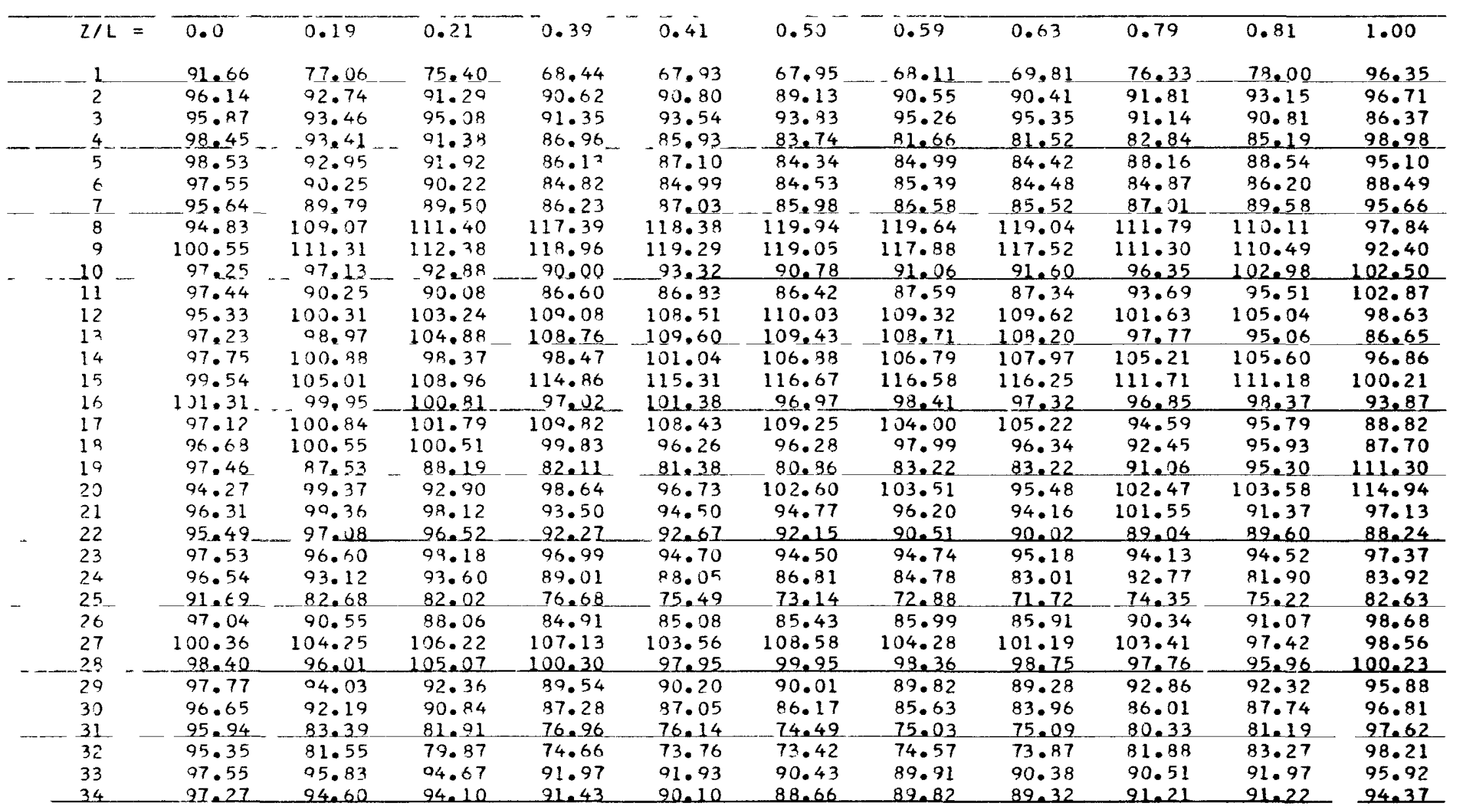


TABLE 17

TYPICAL MIXING FACTOR SHEET

(6)

5 KWE RANDOM CORE RUN $1 A, 12 / 1 / 72$

MIXING FAC TOR, T/IN

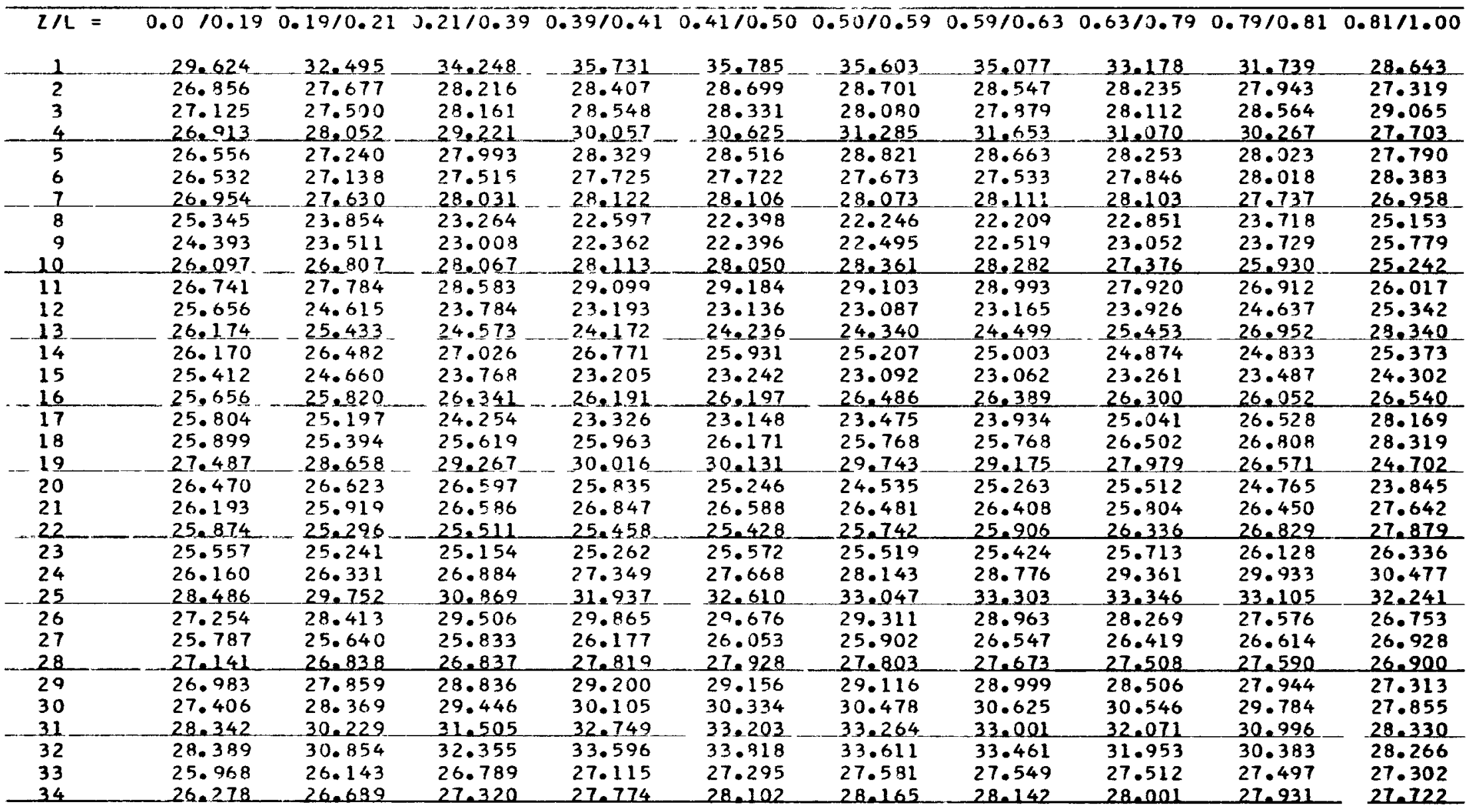


TABLE 18

TYPICAL FILM COEFFICIENT SHEET

(6)

5 KWE RANDOM CORE RUN 1A, 12/1/7?

F TLM COEFFICIENT, BTU/HR-SQ FT- DEG F-

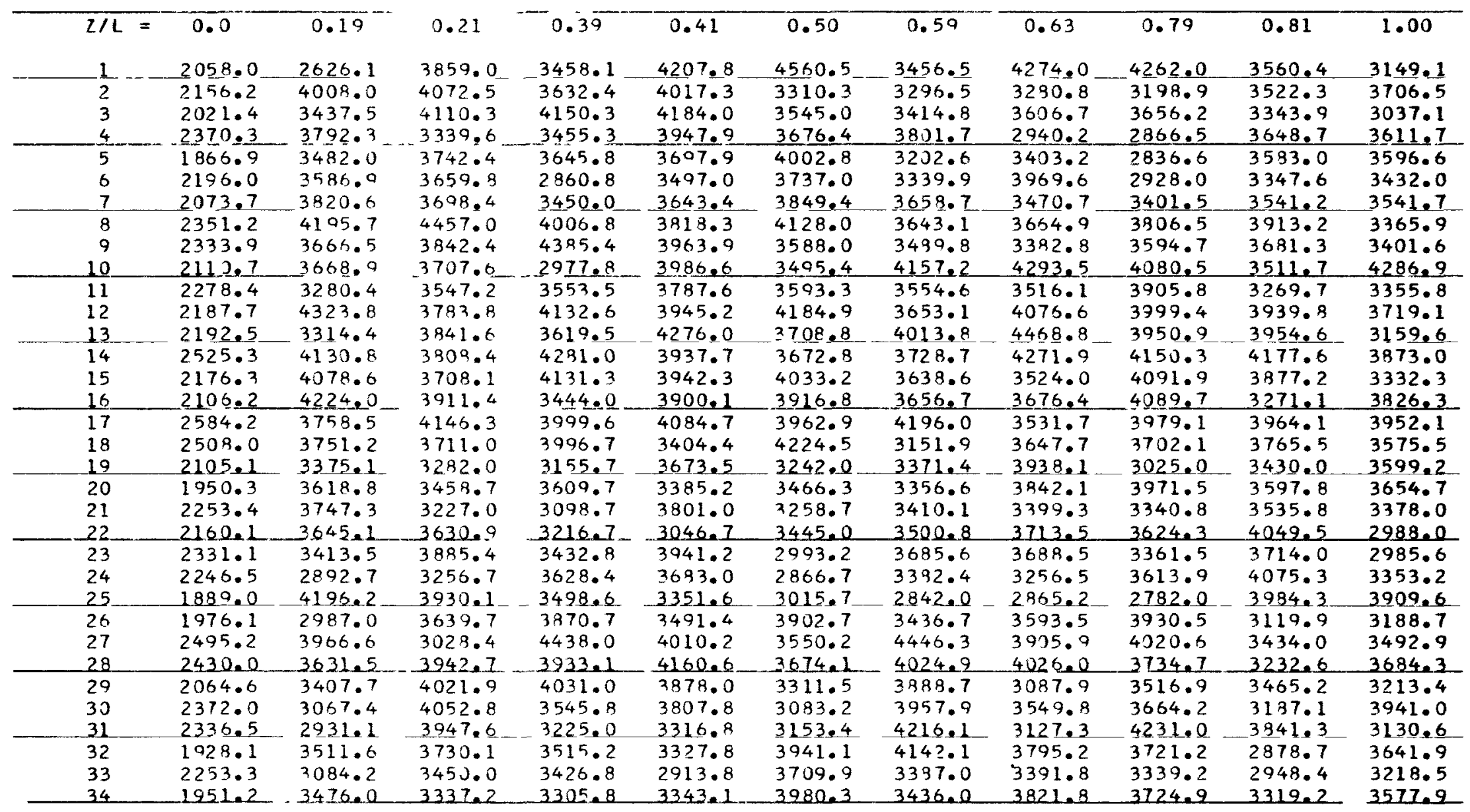


TABLE 19

TYPICAL ELEMENT TEMPERATURE SHEET

(85)

5 KWE RANDOM CORE RUN 1A, $12 / 1 / 72$ ELEMENT NUMBER 1 THERMAL DATA

\begin{tabular}{|c|c|c|c|c|c|c|c|c|c|c|c|c|c|}
\hline & SE G & $Z / L$ & 0.0 & 0.19 & 0.21 & 0.39 & 0.41 & 0.50 & 0.59 & 0.63 & 0.79 & 0.81 & 1.00 \\
\hline & 1 & $\begin{array}{l}\text { TCO } \\
\text { TCI } \\
\text { TGI } \\
\text { TFS } \\
\text { PSEG }\end{array}$ & $\begin{array}{l}1103.33 \\
1104.58 \\
1106.18 \\
1108.19 \\
0.09391\end{array}$ & $\begin{array}{l}1125.30 \\
1129.75 \\
1135.48 \\
1142.23 \\
0.33486\end{array}$ & $\begin{array}{l}1126.85 \\
1130.01 \\
1134.07 \\
1163.28 \\
0.23753\end{array}$ & $\begin{array}{l}1160.60 \\
1164.61 \\
1169.75 \\
1205.49 \\
0.30092\end{array}$ & $\begin{array}{l}1162.80 \\
1165.76 \\
1169.58 \\
1221.33 \\
0.22307\end{array}$ & $\begin{array}{l}1180.79 \\
1183.73 \\
1187.51 \\
1238.19 \\
0.22089\end{array}$ & $\begin{array}{l}1197.94 \\
1200.73 \\
1204.33 \\
1252.20 \\
0.21018\end{array}$ & $\begin{array}{l}1209.40 \\
1213.88 \\
1220.92 \\
1226.23 \\
0.41139\end{array}$ & $\begin{array}{l}1236.07 \\
1239.85 \\
1244.71 \\
1248.22 \\
0.28391\end{array}$ & $\begin{array}{l}1236.17 \\
1238.71 \\
1241.98 \\
1259.39 \\
0.19119\end{array}$ & $\begin{array}{l}1243.29 \\
1243.65 \\
1244.12 \\
1246.65 \\
0.02734\end{array}$ \\
\hline 蛋 & 2 & $\begin{array}{l}\text { TCO } \\
\text { TCI } \\
\text { TGI } \\
\text { TFS } \\
\text { PSEG }\end{array}$ & $\begin{array}{l}1103.07 \\
1104.15 \\
1105.54 \\
1109.99 \\
0.08124\end{array}$ & $\begin{array}{l}1128.52 \\
1132.12 \\
1136.75 \\
1150.87 \\
0.27045\end{array}$ & $\begin{array}{l}1128.62 \\
1130.87 \\
1133.76 \\
1174.24 \\
0.16898\end{array}$ & $\begin{array}{l}1165.31 \\
1168.02 \\
1171.52 \\
1218.82 \\
0.20419\end{array}$ & $\begin{array}{l}1168.80 \\
1171.38 \\
1174.71 \\
1223.49 \\
0.19419\end{array}$ & $\begin{array}{l}1180.70 \\
1183.51 \\
1187.13 \\
1239.58 \\
0.21147\end{array}$ & $\begin{array}{l}1194.43 \\
1197.22 \\
1200.81 \\
1252.40 \\
0.20974\end{array}$ & $\begin{array}{l}1203.61 \\
1208.17 \\
1214.03 \\
1236.73 \\
0.34270\end{array}$ & $\begin{array}{l}1233.36 \\
1236.42 \\
1240.35 \\
1255.45 \\
0.23011\end{array}$ & $\begin{array}{l}1234.54 \\
1236.34 \\
1238.66 \\
1267.10 \\
0.13577\end{array}$ & $\begin{array}{l}1238.92 \\
1239.32 \\
1239.83 \\
1246.28 \\
0.03001\end{array}$ \\
\hline \multirow[t]{5}{*}{ 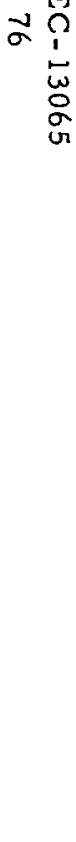 } & 3 & $\begin{array}{l}\text { TCO } \\
\text { TCI } \\
\text { TGI } \\
\text { TFS } \\
\text { PSEG }\end{array}$ & $\begin{array}{l}1101.98 \\
1102.71 \\
1103.64 \\
1113.77 \\
0.05480\end{array}$ & $\begin{array}{l}1121.31 \\
1123.92 \\
1127.27 \\
1161.90 \\
0.19626\end{array}$ & $\begin{array}{l}1124.74 \\
1125.96 \\
1129.83 \\
1173.53 \\
0.16741\end{array}$ & $\begin{array}{l}1158.73 \\
1161.53 \\
1165.14 \\
1219.29 \\
0.21087\end{array}$ & $\begin{array}{l}1164.26 \\
1167.73 \\
1172.21 \\
1214.17 \\
0.26146\end{array}$ & $\begin{array}{l}1182.51 \\
1186.01 \\
1190.51 \\
1232.20 \\
0.26301\end{array}$ & $\begin{array}{l}1193.78 \\
1202.15 \\
1206.48 \\
1246.23 \\
0.25291\end{array}$ & $\begin{array}{l}1204.98 \\
1207.83 \\
1211.64 \\
1253.08 \\
0.22221\end{array}$ & $\begin{array}{l}1228.39 \\
1230.65 \\
1233.55 \\
1265.14 \\
0.16978\end{array}$ & $\begin{array}{l}1230.00 \\
1231.77 \\
1234.04 \\
1267.52 \\
0.13277\end{array}$ & $\begin{array}{l}1237.75 \\
1238.14 \\
1238.65 \\
1246.35 \\
0.02965\end{array}$ \\
\hline & 4 & $\begin{array}{l}\text { TCO } \\
\text { TCI } \\
\text { TSI } \\
\text { TFS } \\
\text { PSEG }\end{array}$ & $\begin{array}{l}1101.70 \\
1102.29 \\
1103.05 \\
1115.33 \\
0.04421\end{array}$ & $\begin{array}{l}1122.25 \\
1124.30 \\
1126.95 \\
1167.82 \\
0.15449\end{array}$ & $\begin{array}{l}1126.29 \\
1129.01 \\
1132.50 \\
1166.93 \\
0.20418\end{array}$ & $\begin{array}{l}1151.79 \\
1155.65 \\
1160.61 \\
1207.81 \\
0.29012\end{array}$ & $\begin{array}{l}1159.20 \\
1164.94 \\
1172.32 \\
1191.05 \\
0.43141\end{array}$ & $\begin{array}{l}1180.10 \\
1185.63 \\
1192.73 \\
1210.44 \\
0.41535\end{array}$ & $\begin{array}{l}1197.81 \\
1203.04 \\
1209.76 \\
1226.27 \\
0.39304\end{array}$ & $\begin{array}{l}1198.38 \\
1201.06 \\
1204.52 \\
1255.47 \\
0.20197\end{array}$ & $\begin{array}{l}1211.65 \\
1214.11 \\
1217.29 \\
1263.91 \\
0.18541\end{array}$ & $\begin{array}{l}1215.10 \\
1217.74 \\
1221.15 \\
1257.40 \\
0.19919\end{array}$ & $\begin{array}{l}1228.07 \\
1228.91 \\
1229.98 \\
1241.69 \\
0.06262\end{array}$ \\
\hline & 5 & $\begin{array}{l}\text { TCO } \\
\text { TCI } \\
\text { TGI } \\
\text { TFS } \\
\text { PSEG }\end{array}$ & $\begin{array}{l}1101.56 \\
1102.20 \\
1103.01 \\
1114.82 \\
0.04765\end{array}$ & $\begin{array}{l}1119.42 \\
1121.71 \\
1124.66 \\
1165.37 \\
0.17241\end{array}$ & $\begin{array}{l}1127.66 \\
1131.86 \\
1137.27 \\
1152.08 \\
0.31628\end{array}$ & $\begin{array}{l}1166.75 \\
1171.68 \\
1178.03 \\
1194.67 \\
0.37094\end{array}$ & $\begin{array}{l}1171.78 \\
1177.25 \\
1184.29 \\
1193.25 \\
0.41124\end{array}$ & $\begin{array}{l}1189.90 \\
1195.37 \\
1202.39 \\
1211.12 \\
0.41074\end{array}$ & $\begin{array}{l}1206.75 \\
1211.94 \\
1218.61 \\
1226.70 \\
0.38985\end{array}$ & $\begin{array}{l}1211.12 \\
1213.78 \\
1217.21 \\
1258.31 \\
0.20023\end{array}$ & $\begin{array}{l}1232.23 \\
1234.24 \\
1236.82 \\
1267.81 \\
0.15100\end{array}$ & $\begin{array}{l}1235.28 \\
1238.19 \\
1241.92 \\
1255.34 \\
0.21841\end{array}$ & $\begin{array}{l}1240.49 \\
1241.06 \\
1241.79 \\
1244.47 \\
0.04276\end{array}$ \\
\hline & 6 & $\begin{array}{l}\text { TCO } \\
\text { TCI } \\
\text { TGI } \\
\text { TFS } \\
\text { PSEG }\end{array}$ & $\begin{array}{l}1102.67 \\
1103.53 \\
1104.62 \\
1112.42 \\
0.06415\end{array}$ & $\begin{array}{l}1123.01 \\
1126.09 \\
1130.06 \\
1156.98 \\
0.23164\end{array}$ & $\begin{array}{l}1129.51 \\
1134.12 \\
1140.04 \\
1147.32 \\
0.34655\end{array}$ & $\begin{array}{l}1169.13 \\
1174.50 \\
1181.41 \\
1189.95 \\
0.40401\end{array}$ & $\begin{array}{l}1171.88 \\
1175.55 \\
1180.26 \\
1213.45 \\
0.27535\end{array}$ & $\begin{array}{l}1189.12 \\
1192.78 \\
1197.49 \\
1230.28 \\
0.27526\end{array}$ & $\begin{array}{l}1206.98 \\
1210.42 \\
1214.34 \\
1245.30 \\
0.25822\end{array}$ & $\begin{array}{l}1213.55 \\
1217.21 \\
1221.92 \\
1245.80 \\
0.27532\end{array}$ & $\begin{array}{l}1234.13 \\
1236.97 \\
1240.62 \\
1259.05 \\
0.21373\end{array}$ & $\begin{array}{l}1236.59 \\
1240.18 \\
1244.79 \\
1249.30 \\
0.26991\end{array}$ & $\begin{array}{l}1241.21 \\
1241.88 \\
1242.74 \\
1243.41 \\
0.05027\end{array}$ \\
\hline & & TFC & 1121.53 & 1189.65 & 1197.01 & 1247.90 & 1251.89 & 1269.40 & 1281.99 & 1284.99 & 1289.07 & 1286.27 & 1250.54 \\
\hline
\end{tabular}


TABLE 20

TYPICAL TEMPERATURE SUMMARY SHEET

(1)

5 KWF RANTIM CORE PUN 1A, 12/1/72

FUEL FLEMENT TEMPERATURE SUMMARY

$\begin{array}{rll}\text { NO } & \text { PEAK } & \text { CHAN } \\ - & \text { FUEL } & \text { DUTL } \\ & & \\ -1 & 1292.1 & 1237.5 \\ 6 & 1312.3 & 1236.5 \\ 11 & 1295.2 & 1229.1 \\ 16 & 1289.7 & 1226.4 \\ 21 & 1285.8 & 1222.3 \\ 26 & 1268.9 & 1206.5 \\ 31 & 1279.7 & 1219.9 \\ 36 & 1271.4 & 1210.4 \\ 41 & 1227.4 & 1194.6 \\ 46 & 1236.7 & 1189.6 \\ 51 & 1241.8 & 1195.4 \\ 56 & 1256.3 & 1199.7 \\ 61 & 1246.2 & 1201.3 \\ 66 & 1202.6 & 1174.2 \\ 71 & 1227.8 & 1179.7 \\ 76 & 1227.5 & 1183.0 \\ 81 & 1218.7 & 1177.6\end{array}$

$\begin{array}{rll}\text { NO } & \text { PEAK } & \text { CHAV } \\ & \text { FUEL } & \text { DUTL } \\ & & \\ 2 & 1305.7 & 1237.4 \\ 7 & 1297.7 & 1235.4 \\ 12 & 1298.7 & 1225.9 \\ 17 & 1290.2 & 1226.1 \\ 22 & 1274.4 & 1215.6 \\ 27 & 1290.3 & 1215.3 \\ 32 & 1268.9 & 1206.6 \\ 37 & 1270.9 & 1216.5 \\ 42 & 1225.5 & 1184.2 \\ 47 & 1245.6 & 1196.4 \\ 52 & 1249.6 & 1201.2 \\ 57 & 1245.4 & 1196.9 \\ 62 & 1223.5 & 1178.5 \\ 67 & 1225.6 & 1194.1 \\ 72 & 1227.5 & 1182.2 \\ 77 & 1232.0 & 1171.2 \\ 92 & 1214.5 & 1173.1\end{array}$

\begin{tabular}{|c|c|c|c|c|c|c|c|c|}
\hline NO & $\begin{array}{l}\text { PEAK } \\
\text { FUEL }\end{array}$ & $\begin{array}{l}\text { CHAN } \\
\text { DUIL }\end{array}$ & ND & $\begin{array}{l}\text { PEAK } \\
\text { FUEL }\end{array}$ & $\begin{array}{l}\text { CHAN } \\
\text {-OUTL }\end{array}$ & NO & $\begin{array}{l}\text { DEAK } \\
\text { FUEL }\end{array}$ & $\begin{array}{l}\text { CHAN } \\
\text { OUTL }\end{array}$ \\
\hline 3 & 1302.1 & 1234.6 & 4 & 1302.5 & $1233 \cdot 6$ & 5 & 1293.6 & 1230.3 \\
\hline 8 & 12 & 12 & 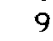 & 1 & 12 & 10 & 12 & \\
\hline 13 & 1285.3 & 1222.8 & 14 & 127 & 1221 . & 15 & 12 & 12 \\
\hline 18 & 12 & 1222.0 & 19 & 1282.4 & 1226. & 20 & 12 & -1 \\
\hline 23 & 1261.9 & 12 & 24 & 1274.1 & 12 & 25 & & \\
\hline 29 & 12 & 12 & 29 & 126 & 12 & 30 & 12 & .2 \\
\hline 33 & 5.6 & 12 & 34 & 1273.5 & 1213.3 & 35 & 1258.3 & 12 \\
\hline 38 & 1240.8 & 110 & 39 & 1245.0 & $1199^{\circ}$ & 40 & 1245.6 & 115 \\
\hline 43 & $4 \cdot 3$ & .1 & 44 & 1248 & 1198 & 45 & 19.6 & .0 \\
\hline 48 & & & 49 & 124 & 119 & 50 & & .6 \\
\hline 53 & 12 & & 54 & 1218.8 & 11 & 55 & & \\
\hline 58 & & & 59 & 12 & & 60 & & \\
\hline 63. & 12 & & 64 & 12 & 11 & 65 & & \\
\hline 68 & & & 69 & 12 & & 7 & & \\
\hline 73 & 12 & 11 & 74 & 1221.5 & & 75 & 1 & 1186.5 \\
\hline 78 & & & 79 & 1221.7 & & 80 & 1225 & .7 \\
\hline R3 & 1 & & 84 & 1228 & 11 & 85 & 1221.0 & 17 \\
\hline
\end{tabular}


TABLE 21

TYPICAL EDGE HEAT LOSS SHEET

(2)

5 KWE RANDOM CORE RUN 1A, 12/1/72

CORE PERIPHERY HEAT LOSS(-) OR GAINI+), BTU/HR

$z / 1=0.0 / 0.190 .19 / 0.210 .21 / 0.390 .39 / 0.410 .41 / 0.500 .50 / 0.590 .59 / 0.630 .63 / 0.790 .79 / 2.810 .81 / 1.00$

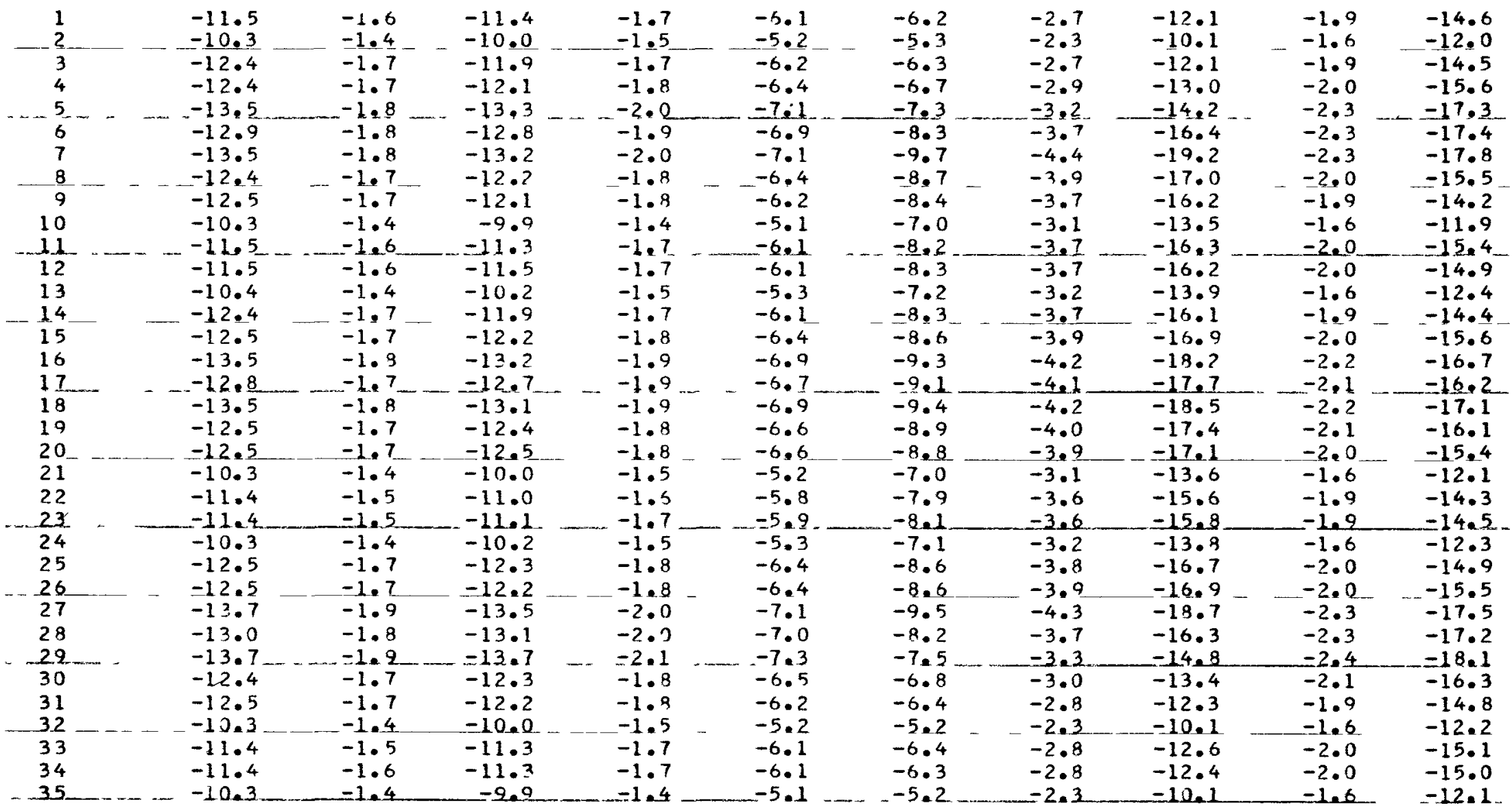


TABLE 22

TYPICAL INTERNAL REFLECTOR CORE SIDE SHEET

(2)

5 KWE RANDIM CORE RUN 1A, 12/1/7?

INNER RFFLECTOR CORE SIDE TEMPERATURES, DEG F

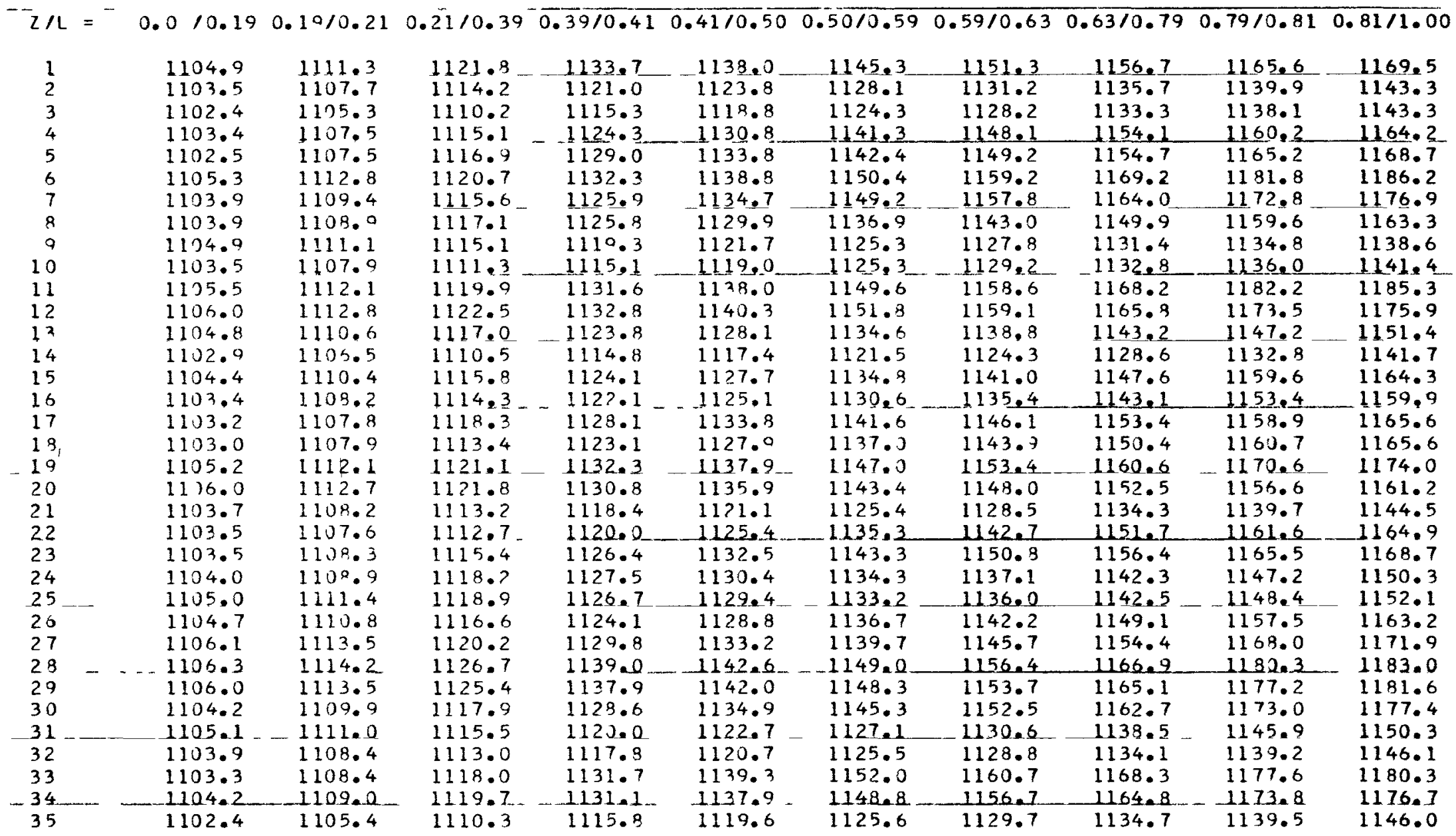


TABLE 23

TYPICAL INTERNAL REFLECTOR SHELL SIDE SHEET

(2)

5 KWE RANDTM CORE RUN $14,12 / 1 / 72$

INNER REFLECTOR SHELL SIDE TEMPERATURES, DEG $\bar{F}$

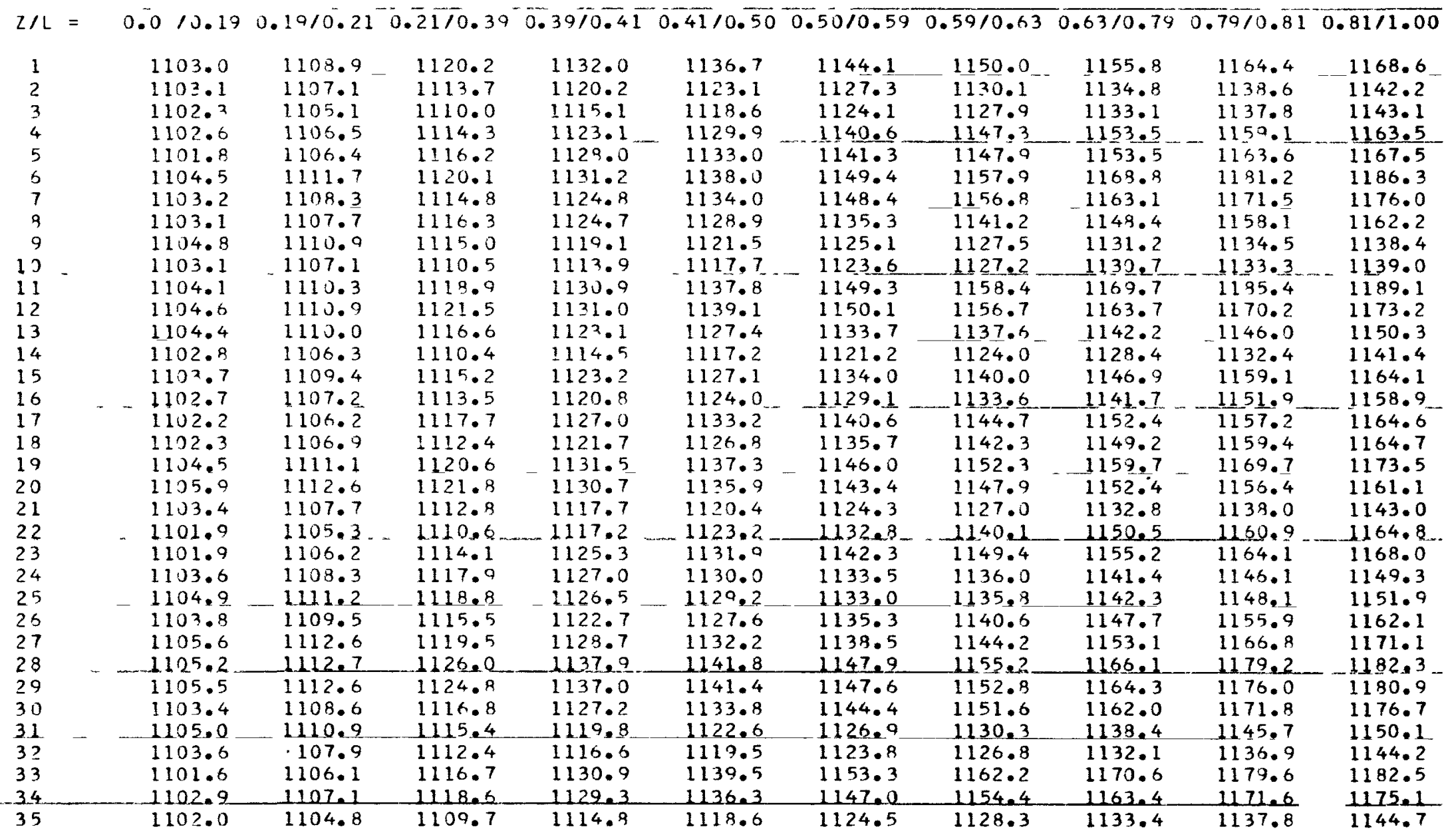


TABLE 24

TYPICAL PRESSURE VESSEL SHEET

(2)

5 KWE RANDOM CORE RUN 1A, 12/1/72

AVERAGE PRESSURE VESSEL TEMPERATURES, DEG F

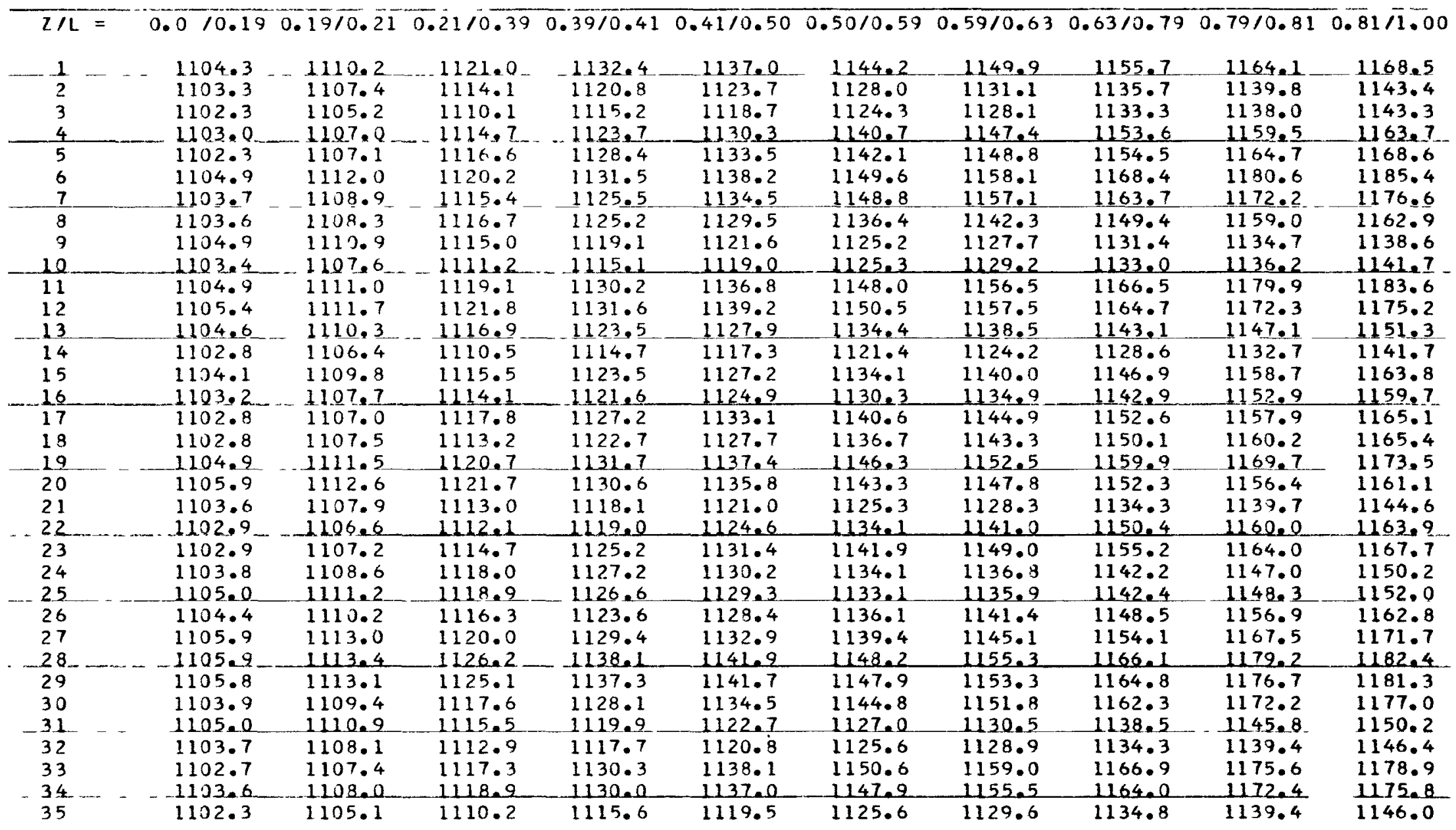


TABLE 25

TYPICAL AREA SUMMARY SHEET

(1)

5 KWE RANDOM CORE RUN 1 A; $12 / 1 / 72$

CORE MATERIAL AREA DISTRIBUTION

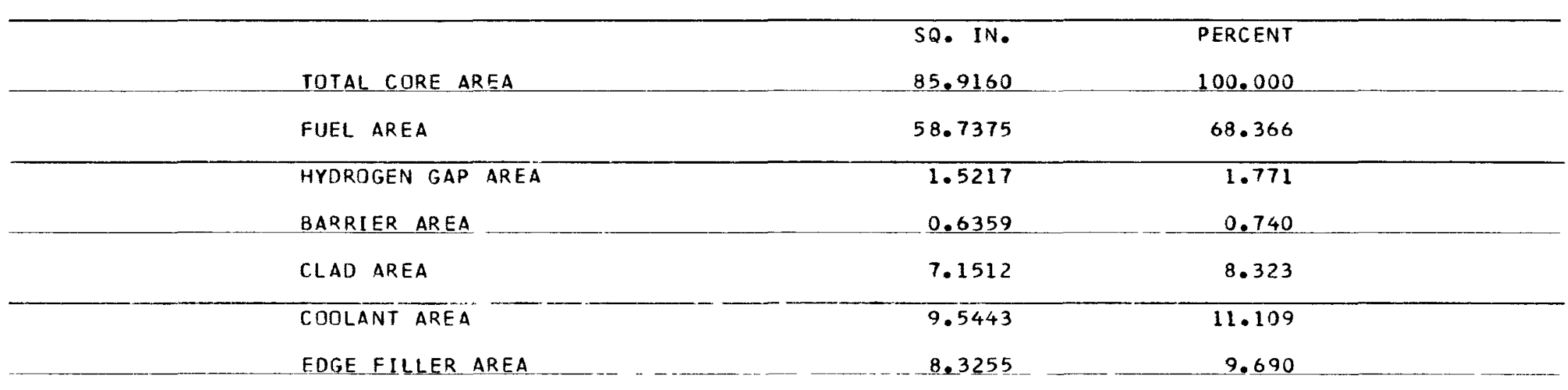

nOte - the above includes aVerage fin area which may vary axially 
TABLE 26

TYPICAL $6 \theta$ RIPPLE SHEET

(29)

5 KWE RANDOM CORE RUN 1A, $12 / 1 / 72$

SIX THETA RIPPLE TEMPERATURES

ELFMENT NO. 1

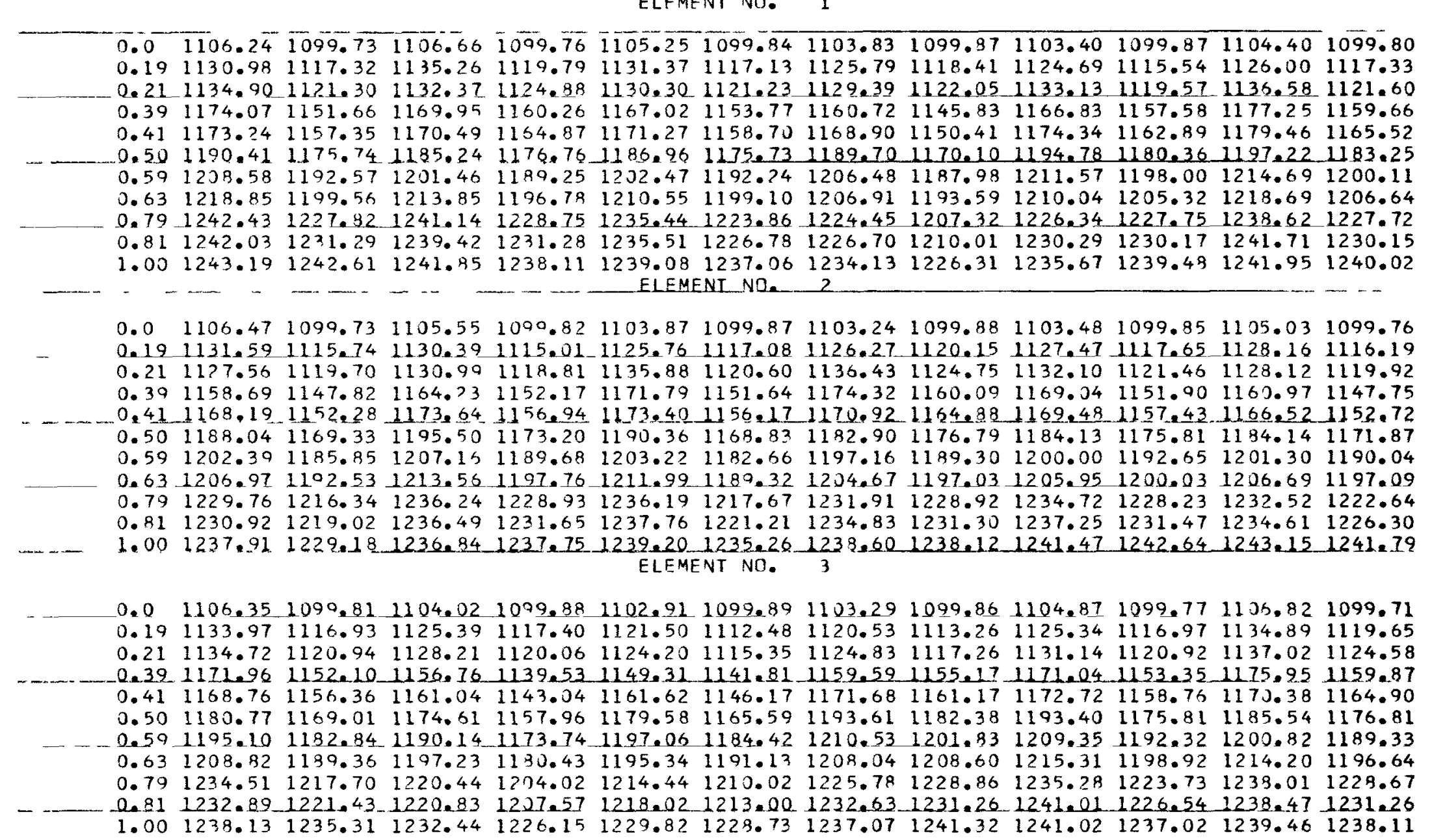


TABLE 27

TYPICAL EQUIVALENT $\triangle \mathrm{T}$ SHEET

(3)

5 KWE RANDOM CORE RUN 1A, $12 / 1 / 72$

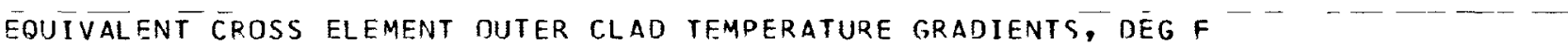

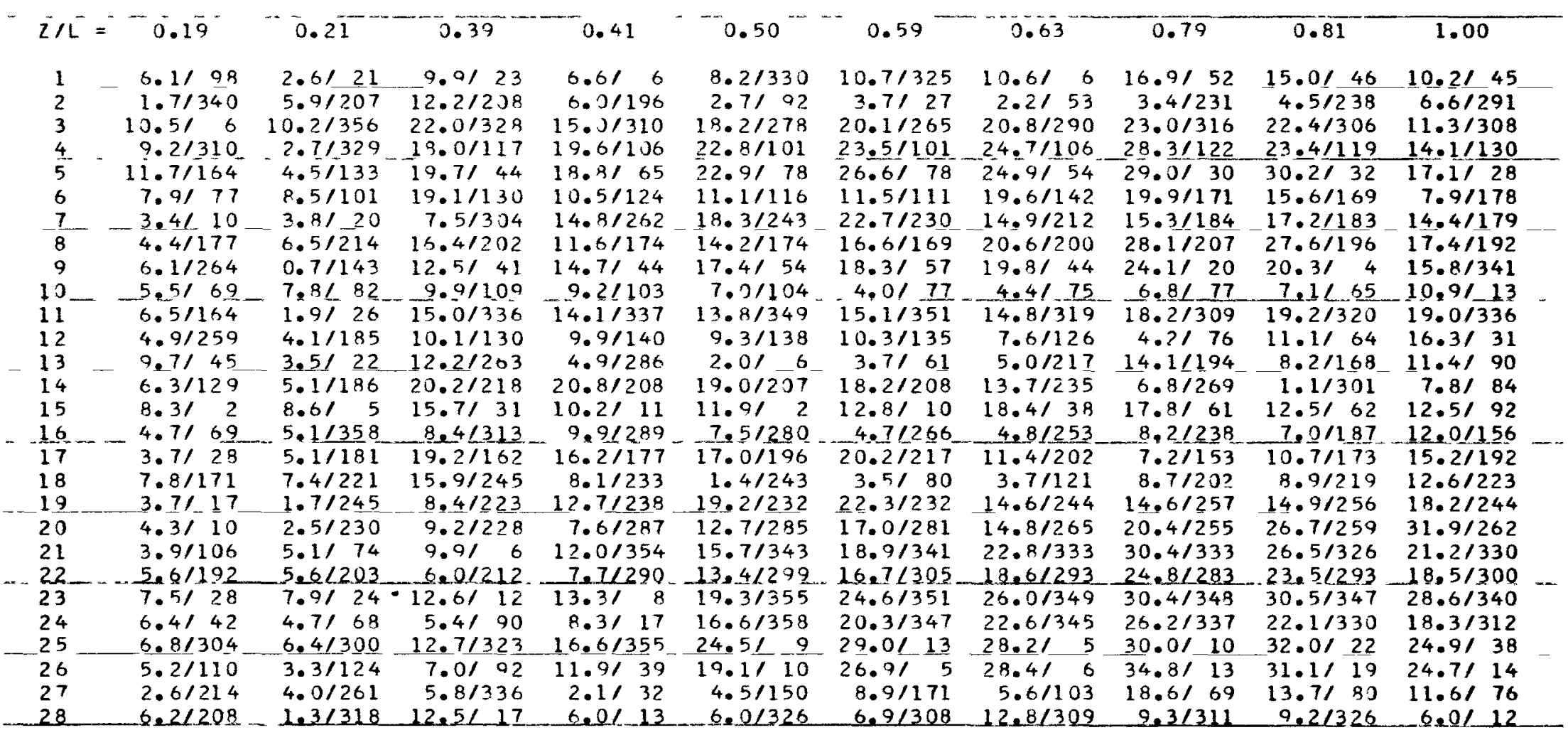


TABLE 28

TYPICAL FORCE BALANCE SHEET

(1)

5 KWE RANDOM CORE RUN 1 A, $12 / 1 / 72$

FORCE BALANCE \& STRESS SUMMARY

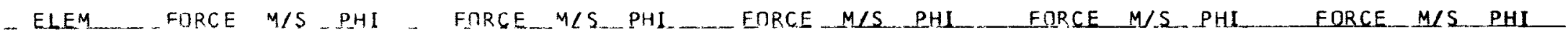

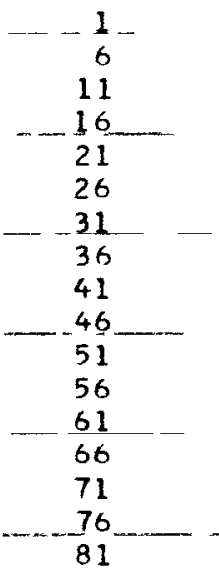

$\begin{array}{lrrlrr}0.47 & 38.47 & 272 . & 0.56 & 47.47 & 23 . \\ 0.08 & 51.67 & 240 . & 0.09 & 49.60 & 64 . \\ 0.03 & 61.24 & 34 . & 0.0 & 54.63 & 308 . \\ 2.46 & 8.24 & 120 . & 0.01 & 60.11 & 300 . \\ 0.01 & 67.99 & 170 . & 0.0 & 87.77 & 148 . \\ 0.0 & 84.41 & 272 . & 0.0 & 78.27 & 297 . \\ 0.0 & 56.67 & 61 . & 2.46 & 8.36 & 300 . \\ 0.00 & 73.51 & 60 . & 0.0 & 83.85 & 165 . \\ 0.0 & 61.97 & 257 . & 0.10 & 73.91 & 0 . \\ 0.0 & 71.34 & 244 . & 0.0 & 45.93 & 272 . \\ 0.06 & 64.00 & 23 . & 0.09 & 54.05 & 120 . \\ 0.10 & 74.99 & 0 . & 0.04 & 79.41 & 300 . \\ 0.06 & 66.29 & 240 . & 0.0 & 93.92 & 103 . \\ 0.10 & 73.18 & 180 . & 0.03 & 94.81 & 120 . \\ 0.0 & 113.02 & 343 . & 0.0 & 104.39 & 232 . \\ 0.39 & 103.49 & 304 . & 0.0 & 63.94 & 357 . \\ 0.0 & 51.32 & 277 . & 0.0 & 90.99 & 16 .\end{array}$

$0.59 \quad 30.76 \quad 155+-0.02-73.05300$

$0.0 \quad 66.30 \quad 235$.

$0.10 \quad 53.17 \quad 355$.

0.06 .30

0.0

65.0139 .

$0.0 \quad 70.90 \quad 324$.

$0.0 \quad 61.06100$.

$0.0064 .55240 .0 .0-45.5444 .20 .0 \quad 63.09348$.

_ CRITICAL ELEMENT 1161 STRESS DETAILS

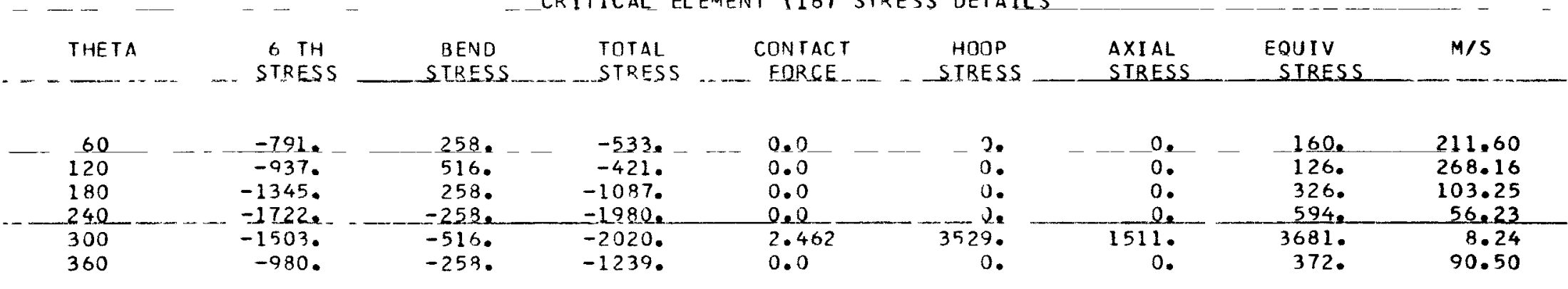

NOTE - ALL DATA IS AT CONTACT $\overline{\text { PLANE, }} \overline{10.6} \overline{\text { IN }}$ 
TABLE 29

TYPICAL STRESS DETAIL SHEET

(21)

5 KWE RANDOM CORE RUN 1A, 12/1/72

ELEMENT STRESS DETAILS

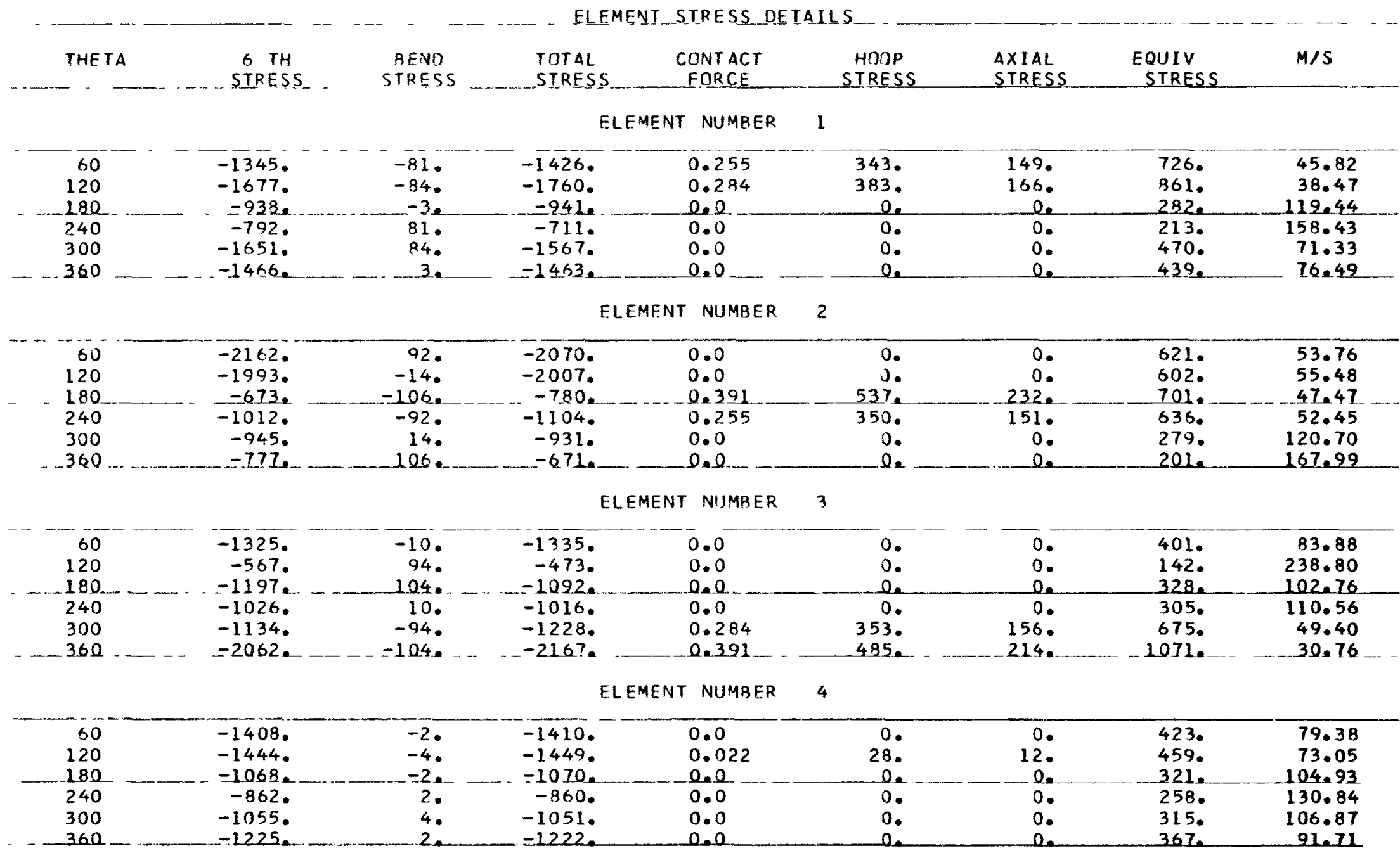




\section{TABLE 30 \\ TYPICAL INTERFERENCE CHECK SHEET}

$$
\text { (11) }
$$

F KINE RANDOY CORE RIIN 1A, 12/05/72

FLFMENT INTERFERENCF CHECK AT FLEVATION 1.0 INCHFS

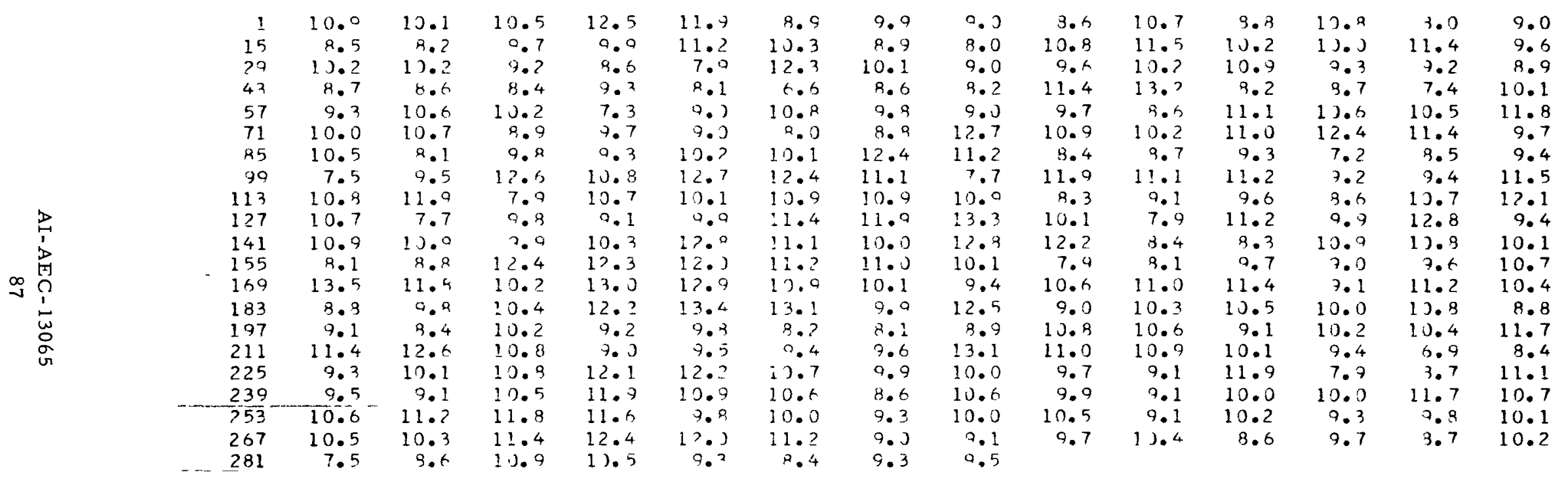




\section{REFERENCES}

1. E. Moody, "Core Sector Thermal-Hydraulic Code GEOM2," TI-696-24-063 (March 26, 1970)*

2. E. Moody, "60 $60^{\circ}$ Core Sector Thermal Hydraulic Code GEOM3," TI-759240-039 (April 15, 1971)*

3. E. Moody, "360 Core Thermal Hydraulic Code GEOM85," TI-653-200-003 (April 19, 1972)*

4. W. A. Sangster, "Calculation of Rod Bundle Pressure Loss," ASME Paper 68-WE/HT-35.

5. D. E. Bourne, et al., "Laminar and Turbulent Flow in Annuli of Unit Eccentricity," CJCE, Vol 46, October 1968

6. A. R. Marchese, "Experimental Study of Heat Transfer to NaK Flowing In-Line Through Tightly Packed Rod Bundles," TR-653-360-001 (October 10, 1971)*

7. L. D. Felten, "Correlation of NaK Film Coefficients and Cladding Temperature Ripple for Input to the GEOM Computer Program," IL (March 1, $1971)^{*}$

8. L. D. Felten, "Thermal Conductivity and Temperature Jump for HydrogenHelium Mixtures," TI-653-240-021 (February 9, 1972)*

9. L. D. Felten, "NaK Film Coefficients and 60 Temperature Ripple for the ZrH Reference Reactor," TI-759-240-038 (April 1, 1971)*

10. E. Moody to J. Asquith, "Heat Transfer Test $6 \theta$ Ripple Correlation," IL $(\operatorname{March} 6,1972)^{* *}$

11. R. A. Castle, "Fuel Element Computerized Stress Analysis with Core Force Balance," TI-652-240-008 (August 25, 1972)**

12. E. Moody to A. N. Nichols, "Simultaneous Equation Solution," IL (January 27, 1972)*

13. E. Moody, "TEMPRO2 - Heat Transfer and Reactivity Lifetime Computer Code," TI-696-24-065 (April 1969) (CRD)

*Internal document, not for general distribution. 


\begin{tabular}{|c|c|c|c|c|c|}
\hline Symbol & Parameter & Unit a & Symbol & Parameter & Units \\
\hline A & Area & $\mathrm{n.}^{2}$ & $u$ & Viscosity, Poisson's Ratio & $\mathrm{lb} / \mathrm{ft}-\mathrm{hr}$ \\
\hline$c_{p}$ & Specific Heat & Btu/lb & $\rho$ & Density & $1 \mathrm{~b} / \mathrm{ft}^{3}$ \\
\hline$d^{p}$ & Diameter & in. & $\sigma$ & Stress, Stefan-Bolzmann & \\
\hline$d_{H}$ & Equivalent Diameter & in. & & Constant & psi \\
\hline $\mathrm{E}$ & Modulus of Elasticity & psi & 0 & Deflection and Force Angles & deg \\
\hline$f_{f}$ & Friction Factor & - & & Power Ratio & - \\
\hline$F_{R}$ & Radiation Emissivity Factor & - & Subscripts & & \\
\hline $\mathrm{F}_{\mathrm{A}}$ & $\begin{array}{l}\text { Radiation Configuration } \\
\text { Factor }\end{array}$ & - & A & Axial & \\
\hline g & Gravitational Constant & $t t / \sec ^{2}$ & A LL & Allowable & \\
\hline $\mathrm{h}$ & Herght & in. & $\mathrm{B}$ & Bending, Barrier & \\
\hline & Heat Transfer Coefficient & $\mathrm{Btu} / \mathrm{hr}-\mathrm{ft}^{2}-^{\circ} \mathrm{F}$ & $\mathrm{BC}$ & Bypass Circumferential & \\
\hline I & Moment of Inertia & $m^{4}$ & $\mathrm{BP}$ & Bypass & \\
\hline$k$ & $\begin{array}{l}\text { Thermal Conductivity, } \\
\text { Constant }\end{array}$ & Variable & $\begin{array}{l}\mathrm{BV} \\
\mathrm{CF}\end{array}$ & $\begin{array}{l}\text { Bypass to Vessel } \\
\text { Cross Flow }\end{array}$ & \\
\hline $\mathrm{L}$ & Length & $\mathrm{Btu} / \mathrm{ft}-\mathrm{nr}-{ }^{\circ} \mathrm{F}$ & cl & Cladding & \\
\hline$M_{t}$ & $\begin{array}{c}\text { Restrdined Moment due to } \\
\text { Temperature Gradient }\end{array}$ & in. $-1 b$ & $\mathrm{CH}$ & Channel & \\
\hline M & Virtual Moment & in. & 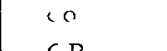 & Coolant & \\
\hline$M_{s}$ & Margin of Salety & - & CR & Coolant to Reflector & \\
\hline$N^{\circ}$ & Number & - & $E Q$ & $\begin{array}{l}\text { Element } \\
\text { Equivalent }\end{array}$ & \\
\hline $\mathrm{Nu}$ & Nusselt Number & - & $\mathrm{f}$ & Fin & \\
\hline $\mathrm{P}$ & Pressure & psi & F & Futl, Free & \\
\hline & Force & $1 b$ & $\mathrm{G}$ & Gap & \\
\hline & Power & $k w t$ & $\mathrm{H}$ & Hoop, Hot End & \\
\hline PD & Power Density & $\mathrm{kwt} / \mathrm{ft}$ & 1 & Denotes Order in an Array & \\
\hline$P_{w}$ & Wetted Perimeter & in. & I & In & \\
\hline$Q, q$ & Heat Flux & Btu/hr & M & Manufacturing, Mixing & \\
\hline $\mathrm{r}$ & Radius & in. & MAX & Maximum & \\
\hline $\mathrm{R}$ & Thermal Resistance & tt $-\Gamma-h r / B t u$ & MIN & Minımum & \\
\hline $\mathrm{Re}$ & Reynolds Number & - & $\mathrm{n}$ & Denotes Numerical Order of Elements & \\
\hline $\mathrm{S}$ & Element to Element Spacing & in. & $\mathrm{O}$ & Out & \\
\hline $\mathrm{S}_{\mathrm{f}}$ & Fin to Element Clearance & in. & $\mathrm{P}$ & Load, Contact Plane & \\
\hline$t$ & Thickness & in. & $\mathrm{R}$ & Radial, Resultant, Reflector & \\
\hline $\mathrm{T}$ & Temperature & $\mathrm{F},{ }^{\circ} \mathrm{R}$ & RB & Reflector to Bypass & \\
\hline $\mathrm{V}$ & Velocity & $f p$ & $\mathrm{RC}$ & Reflector C 1 rcumferential & \\
\hline$w$ & Width & in. & $\mathrm{S}$ & Spring & \\
\hline$\dot{w}$ & Flow Rate & $\mathrm{lb} / \mathrm{hr}$ & $\mathrm{T}$ & Temperature & \\
\hline $\mathbf{x}$ & Axial Distance from Cold End & in. & $\mathrm{t}$ & Thickness & \\
\hline y & Pltch/Diameter Effect on $\mathrm{f}_{\mathrm{f}}$ & - & TOT & Total & \\
\hline z & Fin Geometry Effect on $\mathrm{f}_{f}$ & - & V & Vessel & \\
\hline$\alpha$ & Instantaneous Coefficient of & & $\mathrm{VC}$ & Vessel Circumferential & \\
\hline & Thermal Expansion & $\ln . / \mathrm{ln},-^{\circ} \mathrm{F}$ & $\mathrm{VW}$ & Vessel to Ambient & \\
\hline$\kappa$ & Deflection & in. & $w$ & Wall & \\
\hline$\theta$ & $\begin{array}{l}\text { Circumferentral Angle of } \\
\text { Temperature }\end{array}$ & deg & & & \\
\hline
\end{tabular}

Table 1. Nomenclature 